University of Louisville

ThinkIR: The University of Louisville's Institutional Repository

Electronic Theses and Dissertations

$1-1928$

\title{
The Kentucky-Tennessee boundary line.
}

Charles Hugh Hardesty 1894-1955

University of Louisville

Follow this and additional works at: https://ir.library.louisville.edu/etd

Part of the United States History Commons

\section{Recommended Citation}

Hardesty, Charles Hugh 1894-1955, "The Kentucky-Tennessee boundary line." (1928). Electronic Theses and Dissertations. Paper 573.

https://doi.org/10.18297/etd/573

This Master's Thesis is brought to you for free and open access by ThinkIR: The University of Louisville's Institutional Repository. It has been accepted for inclusion in Electronic Theses and Dissertations by an authorized administrator of ThinkIR: The University of Louisville's Institutional Repository. This title appears here courtesy of the author, who has retained all other copyrights. For more information, please contact thinkir@louisville.edu. 
UNIVERSITY OF LOUISVILلت

THE KENTUCKY_TENNESSEE BJUNDARY LINE

A Dissertation

Submitted to the Faculty

Of the Graduate School of the College of Liberal Arts

In Partial Fulfilment of the

Requirements for the Degree

Of Master of Arts

DEPARTMENT OF HISTORY

By

Charles Hugh Hardesty

1928 
To Professor R.S. Cotterill 
Preface

This dissertation is arranged in three parts. First is a bibliography of the material used in the study with a roster of the officials of each state that may have jurisdiction over any thing pertaining to the boundary line. Second is an account of the various efforts made by each of the states concerned to establish and confirm the line. Chapter one relates the effortsoof the English Government to establish the line between Virginia and North Carolina. Chapter two is an account of the two states to establish the line, enoming the time they declared themselves free of English Government until they ceded their jurisdiction over the land that became Kentucky and Tennessee. Chapters three and four relate the many efforts of Kentucky and Tennessee to establish a boundary line. unapter five is simply an account of the cost to the two states of the final survey made by the Joint Commission of the two states. Part III is a compilation of the documentary sources of the United States and the several states concerned, arranged in chronological order. 


\section{Part I}

A bibliographywith a roster of the officials of the two states. 
The following list of books and publications was used in the preparation of this paper.

SOURCE MATERIAL

American State Papers

Vols37,38.

Government Printing Office

Carroll, John D.

rentucky Statutes

1909,4 th Ed.

Courier Journal Job Printing

Clark's Manuscripts

$\mathrm{V}_{01.50}$

Littell,

Statute Laws of Kentucky

$1808,1822,2$ vol.

Wickliffe, Turmer, and Nicholas

Revised Statutes of Kentucky

1852 A.G. Hodges, State Printer.

Henning, William Waller

Statutes of V1rginia at large.

13 vols. vol. 6.

Richmond, Virginia.

Kentucky Boundaries

Petition Inhabitants of snox County November 51814

Congressional kecord.

Report Joint Commission Kentucky and Tennessee

Journals,

Kentucky Senate

Kentucky House of Representatives

Tennessee Senate

Tennessee House of Ropresentatives

(Official Publicationd)

MacDonald, William. Editor

Select Charters

. $1906,616 \mathrm{pp}$

Mackillan Company, New York

MacDonald, W1llam, Editor

Bocumentary Source Book American History

$1908.616 \mathrm{pp}$

Iacillan Company

New York

Whitney, Henry D. Editor

Land Law of Tennessee

1891,3 parts in $\mathbf{z}$ volume $1136 \mathrm{pp}$. Chattanooga, Tenn. $J_{e}$ ill. Deardorf $f$ and Sons, Prin and Bin. 
Journal

Major Daniel Smith

Tennesee Historical Hagazine

March 1915

Origional in Draper Manuscripts

University of Wisconsin

Secondary Sources

Allen,

History of kentucky

$1872,449 \mathrm{pp}$

Bradley and Gilbert

Louisville, Kentucky

Arthur, T.S and Carpenter,W:H.

History of Kentucky

$1852,316 \mathrm{pp}$

Lippincott Grambo and Co

Philidelphia

Butler, lann

History of the Commonwealth of Kentucky $1834,396 \mathrm{pp}$

$W_{1}$ cox, Dicke man and $C_{0}$.

Battle, Perrin and Knifien

Kentucky ilstory

1888, $930 \mathrm{pp}$

Battey

Louisville, Kentucky

Cyclopaedia American Government

W.F.Wilcox, on Boundaries

12th Census Bulletin 74

1904

Collins, Lew is

History of sentuciny

1882

collins

Covington, Kentucky

Connelly, Mrs. E. M.

Story of Kentucky, Story of the States

Lothrop

Boston, Massachusetts

Cook, Rev.

Old Kentucky

$1908,288 \mathrm{pp}$

Neale Pulishing Co.

New York and Washington 
Coleman, Mrs A. M. (C)

Life John J. Crittenden

1873,2 vols in one

Lippincott

Philidelphia,Penn.

Foote, William Henry

Sketches of North Carolina

$1846,557 \mathrm{pp}$

R. Carter

$N_{\text {ew }}$ York, N, Y.

Garrett,W.R.

Northern Boundary of Tennessee

Mar. 18,1884, before Tennessee Historical Society

Published American Historical Magazine

January 1901

Gannett, $\mathrm{H}$.

Boundaries of United States and of the Several States 1904 , Bulletin 226--

United States Geological Survey.

Henderson, Archibald

Richard Henderson and the occupation of Kentucky 1775

Dec. 1914

Reprint Lississippi Valley Historical Review

Holmes, Avriel

Annals of America

1829,2 vols.

Hiliward

Cambridge, Hass.

Howe, Henry

Historical Collections

$1845,544 \mathrm{pp}$

S.C. Hancoek and Co.

Johngon, E.P.

History of Kentucky and Kentuckians

1912.3 vols.

Lewis

Chicago, Ill.

Jefferson, Thomas

Notes on the State of Virginia

$1802.368 \mathrm{pp}$

H. Sprague

Boston, Hass,

Niles Register

Vol 75 . 
Martin, Francais Xavier

History of North Carolina

1829,2 vols.

A.T.Penniman and $\mathrm{C}_{0}$.

New Orleans, La

Marley, Margaret Warner

The Carolina Mounta1ns

1913,

Houghton Hifflin Co.

New York. N. I.

Moore, John Trotwood

Tennessee The Volunteer State

19 ez 4 vols.

S.J.Clarke,

Chicago, I11.

Kentucky State Historieal Soviety

Register,

srankf ort, $k y$.

Iinkead, E11zabeth Shelby

History of Kentucky

$1896,288 \mathrm{pp}$

American Book Co.

New York. N. Y.

Serr's' History

Connelly, W. .. and Coulter, L. M.

History of Kentucky

1922,5 vols.

American Historical Society

Chicago, I11.

Letters on the condicion of Kentucky 1825

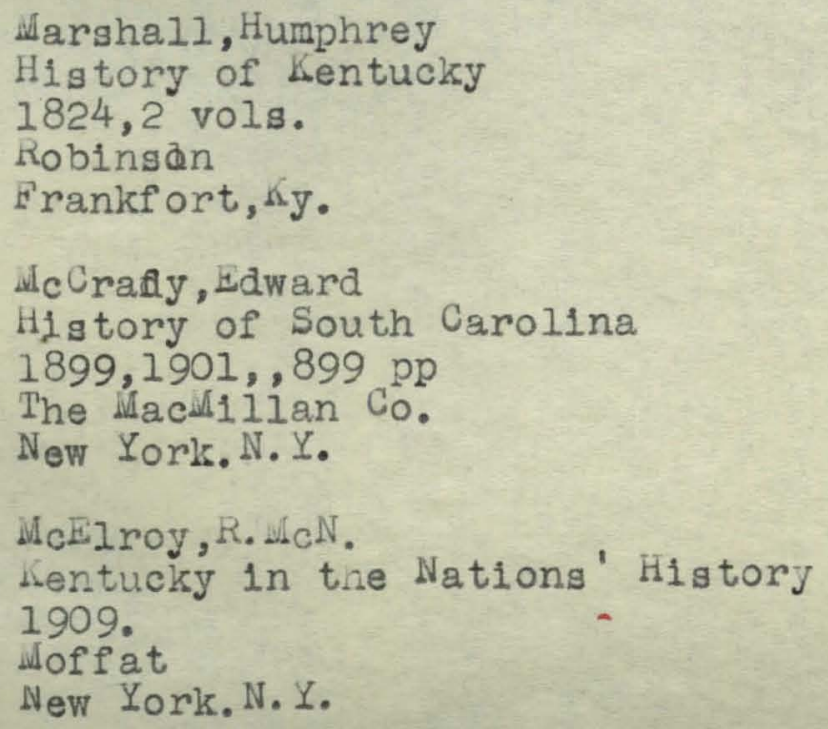


McLaughlan, Andrew

History of the American Nation

$1916,596 \mathrm{pp}$

Appleton and Co.

New York, N.Y.

Ramsay, James G. Lif G.

Annals of Tennessee

$1853,1926,744 \mathrm{pp}$

Walker,

Naskvilie, Tenn.

Smith, Thomas Marshall

Legends of the war of $ı$ ndipendence and opening of the west. $1855,397 \mathrm{pp}$

J. F. Brennen

Loulsville, Ky.

Smith, Zachariah Frederick

History of Kentucky

1901,4 th Ed. 963 pp.

Prentice Press, Courier Journal Job Printing.

Loulsville, Ky.

Sumner, Lewis Preston

History South West Virginia 1746-1786.

1903,921 pp

J.L.ilil Printing Co.

Richmond, $\mathrm{Va}$.

Wheeler,John Hill

Historical Sketches of North Carolina 1584-1851

1851,2 vols.

Lippincott Grambo and Co.

Philadelphia. Pa.

Andrews I.W.

Wanuel of the Constitution of the United States

1887, Van Antwerp Brags Co.

1900, Revised. American Book Co.

New York. N.Y.

State and Colonial Records North Carolina

26 vols, 4 vols Index

(Should be in source material) 
The following list of books was used by Dr. Garrett in the preparation of his paper given before the The Tennessee Istorical Society Warch 181884.

Byrd's History of the Dividing une

Thomas Jeffersons Works.

Cooke's History of Virginia

(Wheeler's History of North Carolina. Ramsay's History of South Carolina

Qdarshall's History of Kentucky

aramsay's Annali of Tennessee.

(a) Haywood's History of Pennessee.

Ridpath's History of the United States.

Charters and Constitutions of the United States.

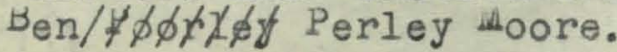

@Statutis, Journals, Revisals, etc., Virginia, North Carolina, Tennessee, and Kentucky.

Qulanuscript Keport of the Joint Commission of Tennessee and sentucky.

(1) Also used in the preparation of this paper. 


\begin{tabular}{|c|c|c|}
\hline $\begin{array}{l}\text { Governur } \\
1,92\end{array}$ & Lieut. Gov. & secretary state. \\
\hline isaac sne 1 by & & $\checkmark$ ames $\forall$ ruwn \\
\hline $\begin{array}{l}\text { James var.rard } \\
1000\end{array}$ & & warsy LuuLmin \\
\hline $\begin{array}{l}\text { James Garrard } \\
1804\end{array}$ & Alexander S. Bullitt & Harry Toulmin \\
\hline $\begin{array}{l}\text { Christopher Greenup } \\
1808\end{array}$ & John Caldwell & John Rowan \\
\hline $\begin{array}{l}\text { Charles Scott } \\
1812\end{array}$ & Gabriel Slaughter & Jesse Bledsoe \\
\hline $\begin{array}{l}\text { Igaac Shelby } \\
1816\end{array}$ & Ridhard Hickman & Martin D. Hardin \\
\hline $\begin{array}{l}\text { George Wadison } \\
\text { Slaughter assumed duties }\end{array}$ & $\begin{array}{l}\text { Gabriel Slaughter } \\
\text { Sct.21 } 1816 .\end{array}$ & $\begin{array}{l}\text { Charles S. Todd } \\
\text { John Pope } \\
\text { Oliver g. Waggoner }\end{array}$ \\
\hline $\begin{array}{l}1820 \\
\text { John Adair }\end{array}$ & William T. Barry & $\begin{array}{l}\text { Joseph Cabel Breckin } \\
\text { ridge, }\end{array}$ \\
\hline $\begin{array}{l}1824 \\
\text { Joseph Desha }\end{array}$ & Robert B. IfAfee & $\begin{array}{l}\text { Thomas B. Monroe } \\
\text { William T. Barry } \\
\text { James C.Pickett }\end{array}$ \\
\hline Thomas B. Letcalie & John Breathitt & $\begin{array}{l}\text { George Robertson } \\
\text { John J. Crittendery }\end{array}$ \\
\hline $\begin{array}{l}\text { John Breathitt } \\
\text { Died Feb. } 2134 .\end{array}$ & $\begin{array}{l}\text { James T. Aorehead } \\
\text { Assumed duties F'eb. 22,34 }\end{array}$ & $\begin{array}{l}\text { John J. Crittendenf } \\
\text { William Ousley } \\
\text { Austin P.Cox }\end{array}$ \\
\hline $\begin{array}{l}1836 \\
\text { James CIark } \\
\text { Died Sept.2',36 }\end{array}$ & $\begin{array}{l}\text { Oharles A. Wickliffe } \\
\text { Assumed duties Oct. } 5,36\end{array}$ & James M. Bullick \\
\hline $\begin{array}{l}340 \\
\text { bert } P \text {. Letcher }\end{array}$ & Lanlius P. Thomson & James Harlan \\
\hline $\begin{array}{l}1844 \\
\text { William Ousley }\end{array}$ & Archibald Dixon & $\begin{array}{l}\text { Ben Hardin } \\
\text { Ge orge B. Sinkead }\end{array}$ \\
\hline $\begin{array}{l}1848 \\
\text { John J. Crittenden } \\
\text { resigned JulJ } 31,1850 \text {, } \\
1.851\end{array}$ & John Helm & Wiliam D. Keed \\
\hline $\begin{array}{l}\text { Lazarus W.Powell } \\
1855 \text { charles }\end{array}$ & John B, Thompson & James P. Letcalfe \\
\hline Charles S.Morehead & James G.Hardy & Mason Brown \\
\hline $\begin{array}{l}1859 \\
\text { Beriah Licuofin }\end{array}$ & $\begin{array}{l}\text { Linn Boyd } \\
\text { Died Dec.ly } 1859\end{array}$ & Thomas B. Monroe \\
\hline
\end{tabular}


Governor

1790

Willam Blount

1796

John Sevier

1801

Archibald Roane

1803

gohn Sevier

1809

Wilie Blount

1815

Joseph - Llinn

1821

Willian Carroll

1827

Samuel Houston

Resigned April 1829

Willam Hall Speaker Senate till Oct. 1829

Vilitam Carrolit

1835

Newton Cennor

1830

James K.Polk

1841

James C. Jones

1845

Aaron V. Brown

1847

Neil S. Brown

1849

William Trousdale

1851

William Campbell

1853

Andrew Johnson

1857

Isham Harrig
Secretary of State

1792

Daniel Smith

1796

William laclin

1807

Robert Houston

1811

W, G. Blount

1815

W1l11am Alexander, diedđ1818 1818

Daniel Graham appointed resigned 1830

1830

T.H. Fletcher

1832

Samue I. Smith

1835

Luke Lea

1839

John S. Young

1847

W.B.A. Ramsey

1855

F.N.W. Burton

1859

J.A.R. Ray 


\section{Part II}

A history of the running and marking of the Boundary Line between Kentucky and Tennessee. 
The Kentucky-Tennessee Boundary Line dispute was passed on to the new states when Virginia and North Carolina ceded their claims to the territory that became Kentucky and Tennessee, and for that reason we look at the dispute they had before we can understand the points over which Kentucky and Tennessee contended for so many years.

The first definite boundary line between Virginia and North Carolina came with the charter of North Carolina granted by King Charles II in 1065. The first charter of North Carolina called for a northern boundary of thirty six degrees, but King Charles granted the new charter in 1665 (1) it read"know ye, that we-.- are graciously pleased to enlarge our sald grant unto them,according to the bounds and limits herafter specified-.-- all that Proviae,territory, or tract of land scituate, lying and being within our dominions of America aforesaid, extending north and eastward as far as the north end of Charahake river or gulet,upon a streight wegterly line to Wyanoake Creek,which lies within or about the degrees of thirty-sic, and thirty minutes northern latitude, and so west in a direct line as far as the Southseas."This made the northern boundary line of North Carolina a line extended west from Caratuck Inlet which was as stated about tilirysix degrees thirty minutes. So long a.s no settlements were made near the boundary no trouble grew out of the true position of the boundary line. Such a condition could not be held long with the rapid expansion in all directions of the colonies.

The first effort to establish and mark the boundary line was made in $1710(2)$ when 1t was found the Colonists were disputing as to whether they owed allegiance to the Royal Province of Virginia or the Proprietay Government of North Carolina.Commissioners were appointed flom the two Governments to settle the dispute but werenever able to agree upon a stating point by a difference of some fifteen miles. Unable to do any- 
thing they separated, the Royal Commissioners from Virginia made a report to Queen Anne in which they brought some serious charges against the Commissioners of North Carolina(3)A similar charge was brought by the Virginia Council on March 1,1710. (4) in which they make the claim that the Carolina Commissioners were personally interested in the land and consequently would not make a fair and hon est survey of the land.

The next Commission of Virginia dated December 14.1727(5) was composed of Sir William Byrd, Richard Fitz William, and William Dandridge Esquires who were to meet the Proprietary Commissioners of North Carolina(6) compoged of Sir Richard Everard, Governor, Christopher Gale, Esquire, C lef Justice, John Lovick, Esqr. Secretary, Edward Lose Iy Esqr, Surveyor General, and William Little Esqr.Attorney General. This Commission me the Virginia Commission on Warch 6 1728(7) and after some disputes agreed upon a starting place on the north shore of Carrituck Inlet. A cedar post was set wo mark the starting point and 1ts lattitude determined as $3631^{\prime}$. They ran a due west course as they supposed by allowinga 3 degree varlation of the needle. (8) They passed through the Dismal Swamp and Colonel Byrd says in his book entitled"The History of the Dividing Line" we gained immortal reputation by being the first of mankind that ever ventured through the great Dismal. (9) Colonel Byrd's account of this survey give us our fist real understanding of the dispute, Written in the humor of this famous Virginian, even so dry a subject,proves to be very interssting and readable. This Joint Commission ran the line to Buzzard Creek(10) about one hundred sixty-nine miles, where the North Carolina gentleinen left them on Jetober 5 1128,protesting the line not be continued farther. Colonel Byrd and wr Dandridge continued the line some seventy-two miles to Peter's ureek a tributary of the Dan Kiver,where the termination was marked on a Red Jak 
October 26,1728 . wost of this line it can be seen from the latitude glven at the start was at least a mile above $3630^{\prime}$ The genial but not tempered Colonel Byrd shows his indighation at the people of the border desiring that their lanas be in North Carolina, in the following "We constantly found the Borderes laid it to heart if their land was taken into Virginia. They chose much rather to belong to Carolina, where they pay no tribute to God or Caesar" (11)Colonel Byrd takes a parting shot at the Carolina Commissioners and Mr. fitz-William when he relates, "They stuck to us as long as our good Liquor lasted, and were so kind as to drink our good journey to the mountains in the last bottle we had left":(12)Another explanation of tie North Carolina Commission's with drawal is given in the following lines, "These ventlemen had a stil stronger reason for hurrying back to Williamsburg, which was that the General Court might ${ }_{\Lambda}^{\text {lose }}$ an able judge nor himgelf a double salary". (13) Colonel Byrd and his party had surveyed and marked the line some 241 moles and 30 poles to Peterls Creek and as he expresses it," within the shadow of the Chariky Mountains where we set up our pillars like Hercules and returned home". (14) In concuding his narative col. Byrd attempts to justify his action in continuing the line in these words, "Nor can we by any means reproach ourselves of having put the Crown to any exhorbitant expense in this difficult affalr, the whole charge from beginning to end amounting to no more than $1000 \mathrm{~L}$. But let no one in this painful Expedition complain of the scantiness of his pay so long as His wajesty has been graciously pleased tu add to our Reward the Honour of his Royal approbation, and to declare, notwithstanding the Desertion of the Carolina comissioners, that the line by us run en shall hereafter stand as the true Boundary betwixt the Governments of Virginia and North Carolina."(15)

The second successful attempt to locate the boundary line between Virginia and North Carolina was in 1749 when the line was extended 
from reter's Creek to Steep Kock Creek, a distance of eighty-eight miles, making in all a distance of 329 miles that the line had been surveyed frompd the coast. (16) The most interesting thing about this Joint Commission was that it was the only one of the four appointe d by Virginia and North Carolina that did not end in a dispute. Jeter Jefferson,father of Inomas Jefferson, Joshua Fry, rrofessor of Wathematics in Mary and Willam College were the Commissioners from Virginia, while Daniel Weldon and William Churton represented North Carolina. North Carolina had by this time become a Koyal province so we have thet two Commissione receiving their authority from the same source. Inis concludes the efforts of the English Government to locate and mark a boundary line between the Royal Provinces of Virginia and North Carolina.

\section{References}

1 Document $21 \mathrm{pp} / \mathrm{l}$ Documentary Source Book, wacQonald.

2 p. 22. Northern Boundary Tennessee, Garrett

$3 \stackrel{2}{2} 22$ ibid.

4 ibid 22

51 Did 23

- 1 bid23

Ibid 24

ช

9

10

11

12 bid 25

13

14

15

16 


\section{Chapter II}

Three years after the signing of the Declaration of Independence and while the colonies were still fighting for the lndepende nce they had declared, Virginia and North Carolina find they must extend this line to the westward, to avert any dispute over lands that mayt ensue from the rapid expansion which must followithe ceasin $f$ of hostilities. Virginia and North Carolina both had promiged lands to their soldiers who had seen service in the Revolution. Virginia began the negotiation in October $1778(11)$ by requesting a joint Commission of the two states to extend the line to the lennesse e Kiver. A reciprocal bili/was passed by the General Assembly of North Carolina. Doctor Thoma.g Walker, the surveyor, and James Madison, probably a cousin of the statesman,were appointed from Virginia. James Madison did not serve, and Major Daniel Smith, foremost mathematician of the time was pronoted from the position of surveyor to that of Commissioner on the part of Virginia. The North Carolina Commission (19) was composed of Colonel Richard Henderson, Colonel John Williams, Najor William Baily Smlth, James Kerr and Urandatus Davis, any three of whom might serve. The first three names listed composed the Commission from North Carolina. The Virginia Commissioners met on the fifteenth of August 1779 and began their work in preparation for running and marking the line. They were jolned near the beginning place, where Jefferson and Fry left of $f$ at Steep Rock Creek, by. the Commissioners from North Carolina, September the first. It was the eighth of the month before the latitude of t he place was agre ed (20) upon and the surveyors set to work. The following week the Carolina Genulemen were of the opinion that the line was to far south. The two Commissions took some time to talk with theIndians at the wong Island of the Holston before they settled the disputed latitude. October llth they began to measure off a north course. 
Colonel Henderson and Doctor Walker continued the line west while Wajor Daniel Smith and Colonel John Williams ran the line back east. The two groups observed for some tajys and the Virginia Commission concluded the origional line and not the new line wag correct. This line had been mun had been run sixty-nine miles with the mutual consent of the two Commissions. The Carolina Commission would not consent to extend the origional $\wedge$ farther west nor would the the Virginia Gomision congent to move north to the new line. The North Carolina Commission witharew at this time and protested a continuation of the old line by the Virginia Commssion. Doctor Walker and Lajor Smith continued the line to the Tennessee River,with a gap of land left unsurveyed, in what later became Southern Kentucky. This strip had no trees to mark and was devold of forage for their pack horses. This was the line that later became the famoug "Walker Line".

Having completed this line to the banks of the Tennessee, Walker and Smith began their journey home. They traveled only a short distance until they met Colonel Henderson, who delivered to them a letter (22) from Thomas Jefferson, Governor of Virginia, directing them to go to the falls of the Ohio, secure a guard from Colonel George Rogers Clark, and descend the Ohio and Lissigsippi Kivers to a termination of the line and mark it so no nation could tresspass unknowingly on the soil of Virginia. This duty was accomplished on day 11 1780. The

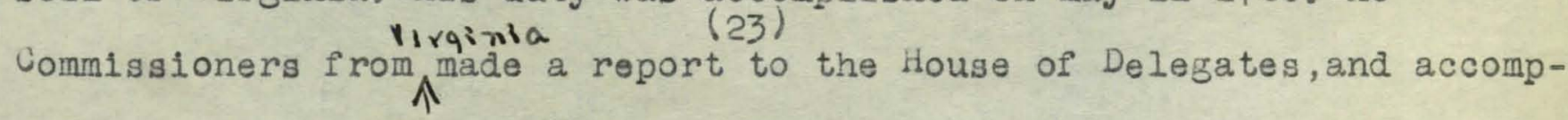
anied it with a plat of the line they had surveyed and marked. Later when Kentucky and Tennessee tried to settle the boundary line dispute, Major Smith writes a letter (24) explaining their work of uhat hard winter. Colonel Henderson, after the withdrawal of the North Carolina Commission, reports to Doctor Walker and Major Smith that he is certain North Carolina will sanction what the Virginia Commission has done, 
however it lwas ten years before either state accepted the line as run and marked by Doctor Walker and Najor Smith. (appendices 9 10 11)

December 181789 Virginia granted Kentucky the privilege of becoming an independent state. The requirements of the compact were met and Kentucky became an independent state June 1 1792. While Lentucky was undergoing the process of becoming a new state, North Garolina was perfecting her plans to cede her western territory to the United States. North Carolina relinquished her claims to the United States February 25 1790, which it seems would eliminate North Carolina from the controversy. The eleventh of the following De cember North Carolina confirmed Walker's Line as the boundary line (25)

between her and Virginia. It was not until December 7 l(91 that Virginia confirned Walker's Line as her southern boundary. (26) This certainly was intended to settle the boundary question between the soverelgn state of Virginia and North Carolina, for neither state mentioned their western lands that had been ceded. The compact with Mentucky was for the land known as Kentucky County with a southern boundary of $3630^{\prime}$ and the decd of Gession from North Carolina gave as 1t's northern boundary $3630^{\prime}$. This brings the dispute between Virginia and North Carolina to an end with a definitely established boundary line.

The Territory So th of the River Unio and the State of Mentucky are now independent of the mother states, and have as their chartered boundaries $3630^{\prime}$ for a dividing line. The location of this boundary line was not established and marked on the land, nor would either the Second or Third Congresses establish Walker's Line as the boundary. There is no definite position est blished upon the land, the jurisdiction of Virginia and North Garolina is ended, so the dispute must be settled by those who come into jurisdiction at a 
later date. Kentucky and Tennessee beginning their existence as new states write into their constitutions 3630 'as a boundary line.

17 appendix 1

18 ibid 3

19 Laws of North Carolina vol 24 pp 223.

20 Appendix 20 Smiths Journal Wed 8th Sept.

21 ibid 25

22 ibid no 5 pp 8

23 lbid no 6 pp 9

24 ibid no 8 pp 41

25 ibid no 9 pp 45

26 ibid int 11 pp 47

27 ibid nos $16,17, p p 51,52$. 
- Doctor Thomas Walker was born in King and Queen's vounty Virginia January 25 1715. Nothing is known of his early life. In 1741 he was married to Mrs. Nicholas Nerriwether( Mildred Thornton). Tnrough this marriage he received 15000 acres of land. This estate was located east of Charlottesville where he built the well known home called Castle Hill. His wfe was a second cousin of George Washington, and the mother of their twelve children all of whom grew into prominance in their community and state. Dr. Walker was the chairman of the Virginia Commission to extend the line to the west for he having spent some time in the backwoods country in 1750-51, was better prepared for the undertaking than those without experience.

\section{Genepal Daniel Smith}

General Daniel Smith was born Stafford County Virginia October 24 1748 and was educated at the College of William and Hary. He became a survejor and in 1773 was made Deputy Surveyor of Augusta County, Virginia. In 1774 he mapped the headwaters of the tributaries of the Tennessee River, then called the Holston. In 1779 he was appointed surveyor to run the Iine between Virginia and North Carolin a, but instead was promoted to the position of Commissioner in the room of James Madison. This work was so well done that the next jear he was $r$ recomended as a Commisioner to settlo and liquidate claims in the west by Doctor Walker. In 1788 he was made a Brigideer General in the Miro District, and two years later Secretary of the Territory South of the Ohio. We find him retiring to his estate in 1794 and building thock Castle a widely known show spot of Sumner County. He was a member of the Constitutional Convention in 1796, and twice elected to th Senate of the United States. $(1 / 98,1805)$ He died at Rock tastle in 1818. 
richard Henderson(1734-1785)was born in Hanover County, Virgihia and moved to Granville County, North Carolina in 1762. He studied law and was admitted to the bar, in 1769. being appointed associate justice of the Superior Court. After the Declaration he was reelected to the office but was not able to take office becauge of his part in the Transylvania Company. Losing this great grant of land by the annulment of Virginia Henderson was rewarded with a smaller grant in the western part of Kentucky. After a short residence in Naghville, Te nn. where he practiced law, Henderson returned to North Carolina where he Engaged in far ing on a large scale. Lajor Wililam Balley Smith

William Balley Smith(--- 1818?) was an early pioneer of sentucky was probably born in Virginia and moved to North Carolina.His first noteworthy work was on the cominision to run and mark the boundary line. He enlisted a battalion to accompany Colonel Geore Rogers elark but tis outfit deserted when they reached Louisville and learned whare they were to be taken. Smith brought the first boatload of food to the sttlers in the rrench Licks of Tennessee. Settled in the western $p$ rt of Kentucky near tie Henderson grant where he died. Colonel John Williams

No biographical sketc. was found of colonel Williams. He was a member of the North Varolina Commission and was a participant in the political life of North Carolina after the Commission was dismissed. 
The first of June 1796 Tennessee was admitted to the Union, so we have the two states on an equal status, both sovere由gn states and capable of determining a boundary line between themselves. Kentucky was the first to take up the question of placing a maris upon the land to establish the posit ion of the boundary of the two state $s$ in her act approved December 14,1801. Th1s act called for two c Commissioners to meet Commissioners from the State of Tennessee for the purpose of determining the position of the boundary line between the two states. This act guaranteed the rights of Tennessee and North Carolina should the the new line reach in to what was then thought to be Tennessee,provided the General Assembly of Tennessee would pass a reciprocal act. This provision however was never met, the twenty-second day of December 1802, the General Assembly of Kentucky repealed the act. The next move was made by the State of Tennessee on November 3,1803 in an act empowering a Commission to settle the boundary between the two states. To this the state of rentucky made no response by act of the General Assembly. It was nine years before either state enacted another bill on the question of the boundary line. Tennessee passed ${ }_{1}^{a}$ resolution authorising Commissioners "run and mark the boundary line according to its true position." (31) Kentucky passed a reciprocal act February 4 1812. No line was mun and narked on the authority of these acts of the two General Assemblies. Here the words"True position"were dropped fro the language of the law makers of Tennessee,for on Jctober 21,1812 they passed an act to confirm and establish"Walker's Hine" as the boundary line between Sentucky and Tennesseé.

This was contrary to the constitutional limits of the two states for both had made $3630^{\prime}$ the boundary line in the beginning. Both statea had exercised Jurisdiction to "Walker's Hine"because it was 
supposed to have been run on the paraliel of thirty-six degress thirty minutes, and no other line had been run to correct or supersede 1 t. $1 \mathrm{n}$ all of the controversy thus far neither state had made any claim to lands beyond the constitutional limits $3630^{\prime}$. Kentucky had valldated all land grants down to 3030 , but had not extended jurlsdiction betond "Walker's Line", likewise Tennessee had validated all grants and claims up to $3630^{\circ}$ and had extended jurisdict tion to"Walker's Line"This line had been treated as an imaginary or temporaryline by both states until the true position would be located. The General Assembly of Kentucky did not take kindly to this act of Tennessee, for in their reciprocal measure of sebruary 10 , 1816, they confirmed only that part of "Walker's Line"that had been run and marked and not an extension of the line to cover any gaps that might exist. The gaps were to be extended along the"true position"and connected with "Walker's Line" by a line run directly North or South as the situation may require. Kenticky may have known by this time that the establisment of "Walker's Line"would transfer some two million acres of her land to Tennessee, and if that be true the General Assembly of sentucky considered it beyond their jurisdiction to make such a transfer without the consent of the people to be transferred.

This act of the $\mathrm{i}$ neral Assembly temporarily extended the jurisdic tion of Kentucky, to "Walker'sibine" until such time as the true line could be ascertained. It also guaranteed and claims or gramts of land by Tennessee or North Carolina, that might fall into Kentucky. These provisions were never accepted by the State of I'ennessee. The General Assembly of Tennessee again on November 24,1817 (35) passed an act establishing and confirming "Walker's Line" as the boundary line and applied to sentucry to jointly request a surveyor to be selected by the United States, whose duty it would be to ascertain the 
termination of "Walker's Line" on the Hississippi and extend the boundary line to that termination. Lentuciky could do nothing but protest this act of Tennessee forsaking her Constitutional uimits and attempting to confiscate som two million acres of Kentucky soil. Tennessee would accede to nothing save "Walker's Line".

The Heneral Asgembly of Kentucky by this time had give $n$ up all hopes of conclilition and adjustment by joint commission. ¿very act concerning the boundary line was repealed January 18,1818 and the next day trey appealed to the Congress of the United States to settle the question or to make some law whereby the question could be amicably settled. Congress did hothing further thath to give some fatherly advice to compromise their dispute and live peaceably with each other.

Immediately after the Chickasaw Treaty, Kentucky requested from (38) Tennessee a joint commission of the two states to run and mark the dividing line west of the Tennessee Kiver according to the constitutional limits of the two states. The Governor of Te nnessee replied it was beyond his jurisdiction to appoint commissiomers for this purpose and protested Kentucky executing that part of the act which provided for running and marking the line if the State of Tennessee should for any reason fall to cooperate in extending the boundary line. Tennessee didfail to cooperate in running and marking this line and the Governor of Kentucky appointed kobert Alexander and Luke Uunsell Commissioners to run and mark the boundary line. This piece of work was dompleted and reported to the Governor of July $26,1819$. (40)

The General Assembly of Tennesee on November 231819 passed an act to send two commissioners to treat with the General Assembly of Kentucky relative to the establishment of a boundary line between the twi states. (41) The State of Tennesee selecte as her Commissioners 
(3)

Felix Grundy and William L. Brown two prominent lawyers of the state. Grundy and Brown "well aware of the high responsibility they had undertaken, and of the important consequences which were to ensue from their conduct, and aware also, of the splendid talents which it was well known the State of Kentucky would put in array against them, they set forward, arrived at the place where the Legislature of Mentucky were in session, presented themselves and made known their Commission. They opened and conducted the negotiation with ability and succeeded in making a convention". (42) lientucky selected for her Commission John Crittenden and John Rowan, two very able lawyers of the state. The Joint Commission instead of sitting as a body followed the suggestion of Rowan, in that the Commissioners from each state retired to aeparate rooms and put their proposals in the form of a written message. Thus we have a written report of the negotiation affecting this covenant. After some days of negotiation the Gentlemen from Lentucky were divided in their opinion, and unable to raach any sort of agreement. The Commissioners from lennessee appealed to the Governor of Kentucky and the Congress of the United States for gome hope of a way of adjustment. Crittenden (43) and Rowan (44) wrote separate reports to the Governor, each stating his stand upon the question and each refused to accede to the terms of the other.Hopelessly divide d on the issue John Rowan tendered his resignation to the Governor and Robert Irimble ${ }^{(\pi)}$ was appointed in his room. It is very evident that he was of the same opinion ag Crittenden for within twenty-four hours of his appointment the signed agreement was handed to the Governor.

This agreement was a compromise in which neither state lost anything over which they had actually exercised jurisdiction. East of the Tennessee River, "Walker's Line"was established as the boundary Iine, below which Kentucky had never exercised jurisdiction. We st of the Tennessee River, Alexander and Uunsell's line was to be the 
boundary line. Tennessee had not exercised jurisdiction notth of this line,for her act of November 27 authorizing the surveyor to seize the land to to an extension of "Walhers Line" was not to take affect, unless the Joint Commission failed to make an agreement. This agreement of the Joint Commission, with a few minor changes, has continued to be the dividing line of Kentucky and Tennessee.

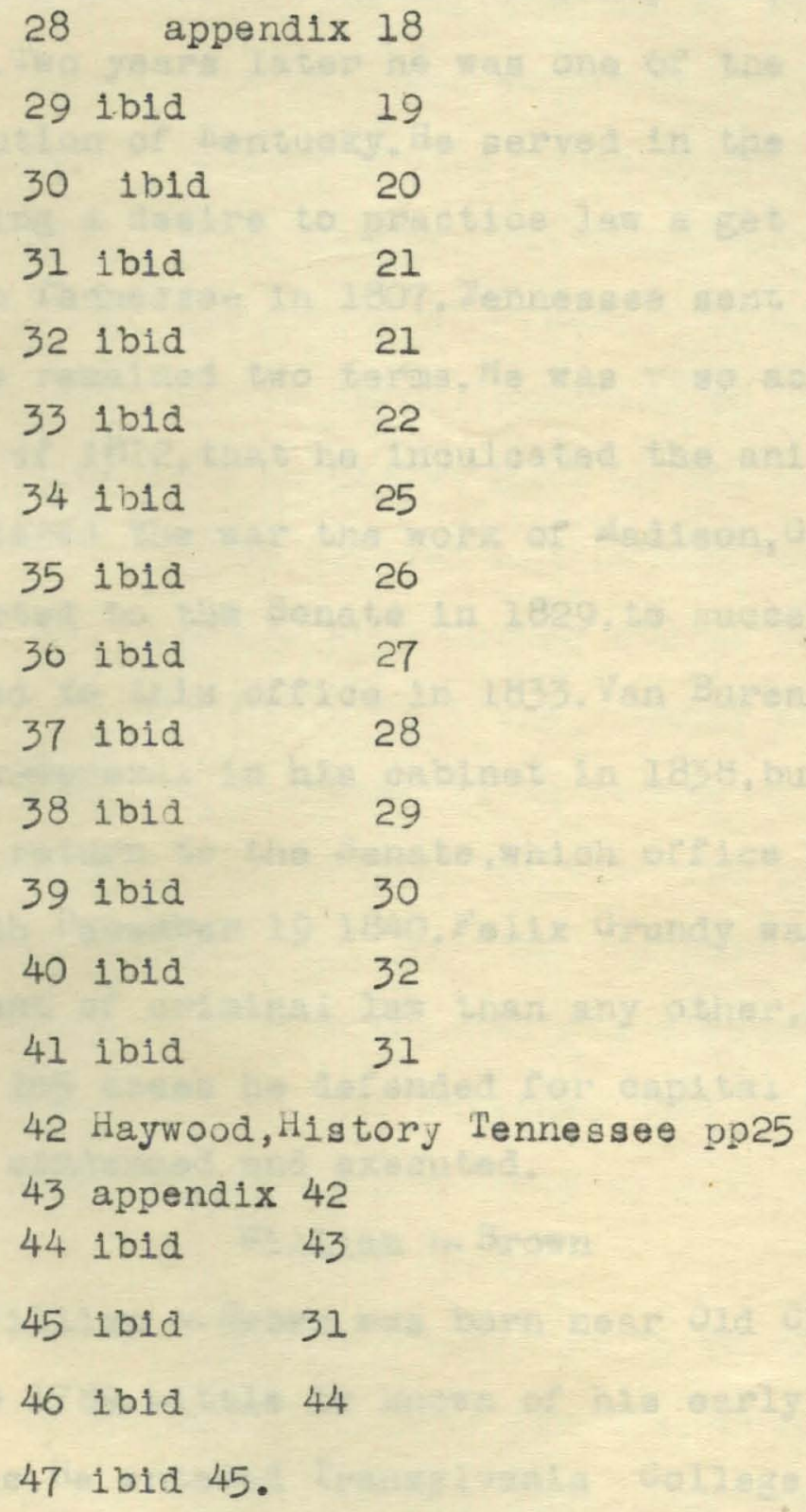


(1)

Felix Grundy was born in Berkeley County Virginia, September 11, 1777. He moved to kentucky at an early age where he grew up under some of the hardships of pioneer life.His mother wanted him to be a doctor, but in the academy of Doctor priestly at Bardstown, he soon proved that he had more of a legal than a medical turn of mind. He gained his mother's consent to study law, and was admitted to the bar in 1797. Iwo years later he was one of the delegates to revise the Constitution of Lentucky. He served in the General Assembly in 1806 , but having a desire to practice law a get away from politics he moved to Tennessee in 1807. Tennessee sent him to Congress in 1811 where he remalned two terms. He was veso active in the prosecution of the war of 1812, that he inculcated the animosity of the F'ederalists, , who declared the war the work of Madison, Grundy and the Devil. He was elected to the Senate in 1829, to succeed John H. Eaton. He was reelected to this office in 1833. Van Buren gave him the post of At Attorney-General in his cabinet in 1838 , but he resigned the next year to return to the Senate, which office he held at the time of his death December 19 1840.Felix Grundy was perhaps greater in the department of criminal law than any other,for one of his contemporarie says of 165 cases he defended for capitai punishment on one was finally condemned and executed.

$$
\text { Willam L. Brown }
$$

Judge William 4 . Brown was born near Old Cherew South Carolina August 9 1789. Little is known of his early life and his migration to Tennessee. He entered Trangylvania College, Lexington Kentucky, in November 1811. After one years study he returned to Tennessee to be admitted to the bar.Judge Brown moved to Clarksville in 1814 , and was appointed Soliciter-General by Governor Willie Blount. He was elected Judge of the Supreme Gourt in 1822 , but resigned the next year.Judge Brown died at Koge Cliff, near Nashville, February 28, 1830. 


\section{John J. Crittenden}

$\#$

John J. Crittenden was born September 10 1786, and received his early education in the schools of his native state,kentucky after which he went to Virginia where his education was completed in Washington Academy and the College of William and Mary. He studied law with the Honorable George M. Bibb and began the practice of law in Russellville Logan County, Lentucky. He was elected to the Lower House of the General Agsembly in 1811 and returnen consecutively until 1817, when he was elected Speaker of the House. During the session he was electe to the United States Senate. Crittenden moved to Franifort in 1819 , and was elected by the people of Franklin County, to the General Assembly for three consecutive terms, beginning in 1825. It was during these yearg he took such an active part in the New and Jld Court wrangle. The Asgembly of 1835 elected him to the Senate again, but his overwhelming law practice soon forced him to resign. He was elected to Senate again in 1843 to $f 111$ the vacancy caused by the resignation of Henry Clay, but resigned it to become Chief Ececutive of his state. The Governorship he resigned to take the post of Attorney-General in the Filmore cabinet. This post he resigned to serve a full tern in the United States Senate. Crittenden was elected to the House of Representives in June 1861 , and retained that office until his death which occured at Louisville Kentycky, July 251863.

\section{John Rowah}

John Rowan was born in Pennsylvania in 1773. At an early age he migrated to Kentucky with his parents. Rowan entered the school of Doctor rriestly at the age of seventeen and was admitted to the bar in 1795. Rowan showed a peculiar code of ethics in refusing to deal in land claims, a practice that was making many Kentucky lawyers wealthy. He was appointed Secretary of State of Kentucky in 1804. Something of Rowan's popularity in kentucky may seen from his election 
to the House of Representatives, in Congress, from a district of which he was not a resident. The next office of note was from 1819 to 1821 as Judge of the Court of Appeals. This office he resigned. Rowan and Henry Clay were appointed in 1823 to represent kentucky in her fight to justify her occupying clalmant laws. The following year he was elected to the United States Senate. Kowan was one of the organizers and first president of the ientucky Historical Society which was organized in 1838. The next year we find him on his last great public mission as Commissioner to adjust the claims of the Citizens of the United States against Mexico. Kowan's home, Federal Hill at Bardstown has become a National Shrine, as"uly Uld Kentucky Home" immortalized by Stephen Collins Foster. Fe died July 13.1843. Robert Trimble

Robert Trimble was born in Berkeley County Virginia and moved to Lentucky with his family at three years of age. Little is known of his early life, except that he taught for a few years, after which he was admitted to the bar in 1803. Bourbon County sent him to the General Assembly the same year. He was appointed second Judge of the Court of Appeals. Robert Trimble did not have a turn for polities for in 1810 he declined the appointment of Chief Justice of Court of Appeals, and on two occasions refused nomination to the United States Senate. He became District Attorney for Kentucky in 1813, and was elevate d to the office of Judge of the Kentucky District in 1816. Ten years late $r$ President John Quincy Adams promoted him to the bench of the Supreme Court of the United States. He died August 251828 in the fifty-second year of his life. 
The boundary line had been extablished but that part of it extending from Cumberland Wountain to the mouth of Obed's River had never beek run and marked. William Steele, the surveyor for Alexander and wunsell, from Kentucky and Absolom Looney from Tennessee were appointed Commissioners to run and mark this part of the line. I'his work of running and marking the gap in the line was completed nd a report with an expenge account attached,was given to to the Governors of the two states July 9,1821. The General Agsembly of Kentucky conflrmel d the report as her southern boundary April 29,1821, and the General Asgembly of Teennessee likewise confirmed the report of the Commisgioners as her northern boundary November 13.1821.

No other controversy arose concerning the position of the boundary line until 1829, when Bright from Tenneseeg, and Munsell from Kentucky were Commissioned to ascertain the line along the southern borde is of Allen, Simpson, and Irigg Counties, of Lentuciky. Govern $r$ Wetcalfe reports this executed in 1830.

December 20,1831 ${ }^{(51)}$ Tennessee passes an Act toestablish the existance and locality of Mathew's Line. When this line was run and its locality has not been ascertained in the research for this pape $r$. There is no contemporary evidence in the Acts of the General Assembly of Kentucky, nor of the Acts of the General Agsembly of Tennessee that such a line was ever run and marked. the boundary line as run and marked by the separate groups of Commissioners was confirmed by the two states and Kentucky and Tennessee were at peace with each other,with the exception of a few minor adjustments, (5R) that came from time to time and were amicably settled. These minor adjustme nts, consisted of stralghtening and marking the line where it had been obliterated, was completed to the satisfaction of both satest by December 1845. 


\section{Part III}

The Documentary Sources used in the preparation of this study of The Kentucky-Tennessee Boundary Line with

A table of contents. 
Appondix 1 Virginia Acts

page 1

Appendix 2 North Carolina Acts

page 2

Appendix 3 North Carolina Act

page 3

Appendix 4 North Carolina Commission's report page 5

Appendix 5 'homas Jeffergon's uetter to Walker page 8

Appendix 6 Report of Walker and Smith page 9

Appendix 7 Journal of Major Daniel Smith page 13

Appendix 8 Gen. Daniel Smlth's Letter, Dec 81815 page 41

Appendix 9 report of Committee,N.C.Legisliture page 44

Appendix 10 wetter of Henry Lee,Goc.Virginia page 45

Appendix 11 Virginia Act,Dec 71791 page 47

Appendix 12 Letter of Jogeph Martin page 48

Appendix 13 wetter of Gilbert Christian paje 49

Appendix 14 List of warrants page 49

Appendix 15 Extract of Gov.Blount's Letter page 50

Appendix $16 \begin{aligned} & \text { Message of Pres.Geo. Washington to page } 51 \\ & \text { Congress }\end{aligned}$

Appendix 17 Neport of Committee in Congress

December 81794 page 52

Appendix 18 Kentucky Act December 14,1801 page 52

Appendix 19 Kentucky Act December 22,1802 page 54

Appendix 20 Iennessee Act November 31803 page 54

Appendix 21 kentucky Act February 41812 page 51

Appendix 22 Tennessee Act Uctober 21,1812 page 59

Appendix 23 Kentucky Act February 31813 page 60

Appendix 24 Tennessee Act Noveraber 171815 page 61

Appendix 25 sentucky Act February 10,1816 page 03

Appendix 26 Tennessee Act November 241817 page 69

Appendix 27 Kentucky Act(Kepeal) January 30,1818page 70

Appendix 28 Kentucky Memorial to Congress

January 31,1819 
Appendix 29 Kentucky Act February 91819

Bage 76

Appendix 30 tetter of Gov. Slaughter April 14,1819

page 18

Appendix 30 Keply of Gov.Jos. Me linn Hay 31919

page 79

Appendix 31 Tennessee Act November 231819

page 80

Appendix 31 Extract of Tennessee Land Law Nov. 27

page 82

Appendix 32 Extract Gov. Slaughter's Message Dec.6 1819 page 83 (Contains keport of Alexander and Munsell)

Appendix 33-41 A series of letters, comprising the correspondence of the Kentucky and Tennessee Committees at Frankf ort, anuary $7-10,1820$.

page $80-93$

${ }^{A}$ ppendix 42 Keport of John J.Crittenden page 94

Appendix 43 report of John kowan page 102

Appendix 44 keport of Acting Gov, to Ueneral Assembly Keport of Gommittee, in General Assembly kgolution of Congrees May 121820 Ratification of Convention February 11,1820

page 129 page 130 page 130 page 131

Appendix 45 report of Steele and Looney Ratification by Tennessee November 13,1821 Ratification by Kentucky April 291821

page 136

page 138 page 139

Appendix 46 Kesolution of Kentucky January 29,1829

page 142

Appendix 47 Bright and Munsell's Line

Resolution of Kentucky, anuary 151831

page 142

page 143

Appendix 48 Tennegsee Act December 20,1831

page 146

Appendix 49 Resolution of Tennessee November 1833

page 147

Appendix 50 Kentucky Act

1833

page 148

Appendix 51 Kesolution of Tennesseefebruary 131836

page 149

Appendix 52 Tennessee Act January 20,1844

page 150

Appendix 53 Kentucky Act January 29,1845

page 151

Appendix 54 kesolution of Tennessee s'ebryary 2,1846

page 152

Appendix 55 regolution to Gov. of Tennessee Jan. 11, 1848

page 153

Appendix 56 resolution of Kentucky February 28,1849

page 153

Appendix 57 Resolution of Tennessee December 2,1851

page 156

Appendix 58 Tennessee Act January 29,1858

page 157

Appendix 60 Resolution of Kentucky December 14,1859

page 160

Appendix 61 Kentucky Act 1860

page 161 
Appendix 62 Resolution of Kentucky February 4, 1800

page 164

Appendix 63 Tennessee Act November 21, 1860

page 164

Appendix 64 Tennessee Act Mareh 8, 1875

page 165 
Appendix 1

B. 1 enacted by the General Agsembly, That two cormissioners shall be appointed by joint ballot of both houses of assembly, who shall have authority to meet with others to be appointed on the part of the sais state of North Carolina, and proceed to extend and mark the line between this commonwealth and the state of North Carolina, beginning wher Joshua Fry and Peter Jefferson, commissioners from Virginia, together with others from North Carolina, formerly appointed to run the sald line, ended their work, and if that be found to be truly in the latitude of thirty-six degrees tinlety minutes north, then to run due west to Tenase river, or if it be found not truly in the sald latitude, then to run from the said place due north or south Into the said latitude, and thence due west to the Tenasee river, correcting the sald course at the due intervals by astronomical observations. If either of the commissioners so to be appointed shall decline or be unable to go through the duties of this appointment, the governor and council shall appoint some other to act in his stead; The sald commisioners shall nominate such skillful surveyor to execute their directions, and such other attendents, as shall be necessary, and shall endeavor to procure the most accurate instruments, which, if injured in the said service,shall be made good at the publick expense or wholly paid for,at the election of the proprietors; if borrowed from ab individual or such other person or persons, as shall have authority to make such election, if borrowed from some seminary of learning. Each commissioner shall be allowed for his trouble herein fifty shillings per day, for every day he shall attend, each surveyor, with the chain carriers and other attendents, shall be allowed such sums as the commissioners shall certify they respectfully ought to recelve, and be paid by the treasurer of this commonwealth out of any 
publick money in his hands, together with the allowance to the commissioners as aforesaid; and the said commissioners and are hereby directed to make report of their proceedings to the general assembly.

And whereas,from the hostile disposition of the Indian Nations, 1t nay be unsafe for the commissioners and their attendents to proceed on the business hereby directed, without a suffleient guard to protect them. Be it further enacted, That the gouernour, with the advice of the council, shall on application of the commissioners so to be appointed, direct and order a sufficient number of officers and men to be raised for that purpose, by voluntary enlistment, or if that cannot be done, then to be furnished from the malitias of such counties as shall be convenient, to attend the said commissioners as a guard and for their safe conduct in the prosecution of tiseir business by this act directed shall order them a sufficient number of tents and camp utensils necessary provisions during the time they shall be employed for the purpose aforesaid; which, commisary shall presious to his entering on the execution of his office, give bind with sufficient security for the faithful performance of his duty, and shall recelve for his services such allowance as is given to other commissaries of this comronwealth.

Uctober 1778

Henning, Laws of Virginia, vol 9 pp565

$$
\text { Appendix } 2
$$

In the House of Delegates Tuesday, the 15 th June 1779 Resolved, That it be proposed to the Assembiy of the State of North Carolina that they pass an act saving to any proprietors of Lands heretofore Considered as a part of this State, but which may, on the extension of the Boundary line,fall into the limits of North Carolina, their several rights and Titles, whether founded on patents issued in 
this State or on legal surveys of any Sworn Surveyor; and, also, that they give the pre-emption to actual Settlers of the Lands so improved and claimed by them at such Composition money as the Assembly of North Carolina have heretofore Established. This proposition is made to North Carolina because, upon running the Cheroke boundary subsequent to the treaty of Lochaber, it was agreed that a due west course from Sleep rock to the intersection of the Holston river, and down the same, should be a Temporary Boundary until the Line should be ascertained according to Charter which sanctified the Settlement of the County under the jurisdiction of this State, and because it may prevent strife a contention that may otherwise ensue. The Agsembly of Virginia wish the advantage of this Proposition to be reciprocal, and w1ll on their part, secure the like rights to any Citizen of North Carolina who shall on the extension of the said line, fall into Virginia.

kesolved, That the Governor tramsmit a Copy of the foregolng resolution to the Governor, the Speaker of the Senate, and the Speaker of the House of Delegates of North Carolina. Agreed

Agreed by the Senate

Teste:

$$
\text { Will Drew, C.S. }
$$

John Beckley, C.H.C.

A Copy-Beckley,C.H.D.

\section{Append1x 3}

An Act for extending the Boundary Line between this State and the Commonwealth of Virginia.

I Whereas, the Inhabitants of this State, and those of the Common Wealth of Virginia,have settled themselves further Westwardly than the Boundary between the sald two States hath hltherto been extended, and it becomes expedient in order to prevent disputes among such settlers that the same should be now further extended and marked. II $\mathrm{B}_{e}$ it therefore Enacted by the General Agsembly of the State of 
North Carolina, and it is hereby Enacted by the Authority of the same, that Jrandatus Davis, John Williams, Caswell James Lerr, William Bailey Smith and Richard lienderson, or any three of them be, and they are hereby appointed Comissioners with full power and authority to meet with otner Comissioners from the Comon Wealth of Virginia, and to proced to extend and mark the line between that commonwealth anl this state, beginning where Joshua Fry and reter, Comissioners on the part of Virginia, togetier with Daniel Burton and William Churton from North Carolina formerly appointed to run the sald line, ended their work and if that be found to be truly in the Latitule of thirty-six degrees thirty minutes North then to run from thence due West to Tennessee or the Jh1o kiver or if it be found not truly in the sald Latitude, then to run from the said place, due North or due South into the said Latitude, and thence due West to the said Tennessee or Jnio Rlver, correcting the said Course at due Intervals by Astronomical observation, if either of the Coumissioners by this Act appointed shall decline, or be unable to go thro' the duties of his appointment the Governor and Council shall appoint some other to Act in his stead.

The sald Comissioners shall nominate such skilful survejor to execute their directions and such otier attendants as shall be necessary, and shall endeavor to procure the most Accurate instrunents, which if injured in the sald service shall be nade good at the public expence, or wholly paid for at the election of the proprietor if bor cowed from an individual, or of such other person or persons as shall have authorIty to make such Election, if borrowed from any Seminary of Learning, each Comisioner shall be allowed for this trouble herein ten dollars for every day he shall attend, and the surveyor with the Chain Carriers, and other attendants, shall be allowed such sums as the commissioners shall certify they respectfully ought to receive, and be paid by 
either Treasurers of this state out of any public sonies in their hands, together with allowance to the commissioners as aforesaid. And the sald Commissioners ace hereby directed to make report of their proceedings to the General Assembly. And whereas from the hostile disposition of the Indian Nations it may be unsafe for the Commissioners and their Attendants to proceed on the business hereby directed without a sufficient Guard to protect them.

II Be it therefore further Enacted by the Authority aforesald, That the Governor with the advice of the Council shall, on application of the Comissioners, direct and order a sulficient number of officers and inen to be raised for that purpose by Voluntary Enlistinent, or if that cannot be done then to be furnished from the dilitia of such Counties as shall be convenient to attend the said Cominisioners as a Guard and for their safe conduct in the prosecution of the Busimess by this Act directed, shall order them a sufficient Number of Tents and Camp Utensils and shall appoint a Commissary to furnish the necessary provisions during the time they shall be employed for the purpose aforesaid.

$$
\begin{array}{r}
\text { S.R.N.C. Vol } 24 \text { pp } 223-224 . \\
\text { Appendix } 4
\end{array}
$$

Richard Henderson and others (Boundary Comissioners) to Gov. Caswe11.

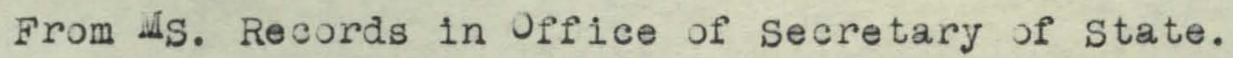
Cumberland Gap. 17 th November, 1779.

Sir.

The great expense in preparation for Extending the boundary line between this state and the commonwealth of Virginia, and the trouble we have been oblidged to give your Excellency on that occasion, might have induced a reasonable hope that the business by this time was nearly complet d. It would afford us great pleasure if that was the cuse. So far has our attempt failed of success tinat we are doubtful very little, if any, benefit will be derived to our state from the 
attempt of the Comissioners to perform the duty enjoined by the General Assembly. We net the Gentn. appointed from Virginia and began the extension to the Westward on the Seventh of September, and after many inevitabie delays for various reasons, we, on the first of November, had carried it on Sixty-seven miles and some Chains, by the unanimous consent of the Comissioners, which brought us to the foot of rowel's dountain, when the Gentlemen from Virginia alledged that the line was, by their observation, too far North; that the error was from the beginning, and that they would not agree to report it as a boundary. On our part we could not agree to an alteration to the south, when by repeated tryal we were fully persualed the line was right, excepting a few seconds to the North. Under these circumstances their proposals of moving two liles and ten seconds to the south was inadmissable.

With this state of the case, your Excellency would naturally suppose all proceedings would stop till the difference in opinion could by some means, be reconciled. The Gentlemen on the other side observed a different line of conduct, without an offer of that kind. Trey infumed us that they cou'd not asree to report the line as it stood, and wou'd make an ofset of that distance. Nentioned, and mark a line at that distance from the one Extended, as well back as forward, and leave the matter to be decided thereafter by artists from both states. Remonstrancescagainst such a proceding were ineffectual; they immediately proceeded, and went on with their line to the East and West at the same time by different Survejors. As the Land uffice for each state was.open as far as Cumberland lountain, we ventured to extend the line due West from the End of that run by unanomous consent to this piace, as it was not far and could be done without much Acoumilation of Expence, and not without some hope of reconciling the difference of opinion. With respect to an accomolation we were great- 
Iy deceived; the Commissioners were Resolved to go on without regard to our opinion or protest against the measure, and we hope to be excused by the General Assembly for continuing the Guard, sce, a few days extending the line to the top of this Mountain, making in the whole a line of Une Hundred Wiles in length, Sixty-seven of which was as before observed, done by the entire consent and approbation of Dostor Thomas Walker \& Iajor Daniel Smith, the Virginia Comissioners. When all hopes of agreeing as to the true latitude were lost, and the partial line run by those Gentlemen carried on, with an express declaration of persisting in the measure, we thought ourselves, bound to dismiss the Escort, we stop our proceding and report the case to the General Assembly. We wish to add, on this subject, that we nave the utmost confidence that the line line run by us is as nearly in the Latitude of Thirty-six Degrees and Thirty minutes North as 'tis possible to place it with the Instruments in our possession, and that we have procured the best in our power; we have also at times had access to the Quadrant nade use of by the Virginians, by which, as well as ours, we are confirmed in the opinion. The difference of Two Winutes and Ten seconds of Latitude in making observations with the same Instruments cannot be accounted for; but the $f$ ict is so, and we have only to lament being concerned in this business. We accept this without $\#$ \# \# \# \# $\#$ the service expected. The very jreat expence of this effort would have nade us yield to anything but a surrender of our integrety, to have established a boundary, and of course prevented the necessity of sending others to perform what we have falled to do as we are about to separate, perhaps not to meet again till next spring or sumner, though it advisable to join in a report to your Excellency of this abortive undertaking. We shall, at all times, separately or together, be willing and ready to give any further or other information as to the particulars of our transaction, and 
Iy deceived; the Commissioners were Resolved to go on without regard to our opinion or protest against the measure, and we hope to be excused by the General Assembly for continuing the Guard, \&c., a few days extending the line to the top of this Mountain, making in the whole a line of une Hundred Hiles in length, Sixty-seven of which was as before observed, done by the entire consent and approbation of Dostor Thomas Walker \& Aajor Daniel Smith, the Virginia Cominsioners. When all hopes of agreeing as to the true latitude were lost, and the partial line run by those Gentlemen carried on, with an express declaration of persisting in the measure, we thought ourselves, bound to dismiss the Escort, we stop our proceding and report the case to the General Assembly. We wish to add, on this subject, that we nave the utmost confidence that the line line run by us is as nearly in the Latitude of Thirty-six Degrees and Thirty minutes North as 'tis possible to place it with the Instruments in our possession, and that we have procured the best in our power; we have also at times had access to the quadrant nade use of by the Virginians, by which, as well as ours, we are confirmed in the opinion. The difference of Two -inutes and Ten seconds of Latitude in making observations with the same Instruments cannot be accounted for; but the $\mathrm{f}$ ict is so, and we have only to lament being concerned in this business. We accept this without $\#$ \# $\#$ if $\#$ the service expected. The very jreat expence of this effort would have made us yield to anything but a surrender of our integrety, to have established a boundary, and of course prevented the necessity of sending others to perform what we have falled to do as we are about to separate, perhaps not to meet again till next spring or sumner, though it advisable to join in a report to your Excellency of this abortive undertaking. We shall, at all times, separately or together, be willing and ready to give any further or other information as to the particulars of our transaction, and 
furnish a Drought of our Line.

We, Sir, are, with great respect,

Your Excellency's most Jbdt, and very Hbl. Servts.

Rich'd Henterson

John Williams

William Bailey Smith.

His Excellency Richard Caswell, Esqr., \&c.

r.S. Here with you'il recelve sundry copies of Letters, a letter from the Virginia Comissioners, as also their requisition for fifty men, all of which your Ex ellency will glease lay before the Gen. Assembly.

The Colonial and State Records of North Carolina.

Vol 14 pp 353-355

Appendix 5

Sir-

WmsBurg, Jan'y 29th 1780

As we propose this spring to take possession of and fortify some post as near the mouth of Uhio as the ground will admit, it becomes very important for us to know the exact latitude thereabouts I take it for granted that your present Line w1ll be stopped befure you get there by unpurchased Lands. We therefore wish extremely that one of you would take a trip to the mouth of the unio with your instruments immediately upon finishing your present work. I suppose it will be best for you to go to the falls of the Ohio where Co1. Clarke has orders to furnish you with Assistants, an escort and all necessaries. You will first find the point at which our tine strikes the Migsissippi or Ohio, and $\mathrm{fix}$ it by some lasting immovable natural mariz if there happen to be any on the spot, or if not, there by 1 ts course or distance from some such natural mark, noting such course as corrected from the errors of variation, and the distance reduced to horizontal measure the reason of requiring this accuracy 
in fixing the point where our Line stikes is, that in future, with common instruments it will be easy to find it which may perhaps be of importance. When you have found this point if it be on the Mississippi run from thence along up the river to the mouth of ohio, and by protraction fix the point of the forks, or if it be on the Ohio, run up that river to where good clifts for fortification shall make in and as you go along note the high grounds, points or clifts on the river which appear to you capable of Works of defence and at the same time to command a view of the river. This done I would ask the favor of you to return one plat of your work to Col. Clarke and another for me. Col. Clarke has in his eye a particular cliff on the Ulssissippi which he expects is the nearest good ground ior fortification. This he w111 discribe to you, and you will please to note it particularly. I am in hopes that it will suit one of jou to undertake this business. We think to have the fort begun, which cannot be till we are assured that the ground we shall pitch on is within our own country. The dissapointment will therefore be of the greatest moment should you decline the Service.

I am Gent' with greatest Respect Your most obedt Hmble Servt. Messrs. Thomas Walker \& Daniel Sinith. Ip 392 George Rogers Clarke Papers, James Illinois Historical Collection Draper MSS 50 (J6-A. L. )

From Thos Jefferson, Gov;Va. Appendix 6

1780 Feb. 25

\section{Report of Comnissioner}

To the Honourable the Spearer and Gentlemen of the House of Delegates.

In obedience to an Act of Assembly entitled, "An act for extending the boundary line between Virginia and North Carolina. 
We the subscribers proceeded to run the said Line,-- The Gentlemen from North Carolina did not meet us so soon as had been agreed; and after they came, many accidents happened which protracted the Business. The place where lessrs. Fry and Jefferson ended their line on Steep Rock Creek, could not be found, owing, we suppose to so much of the Timber thereabout being since dead. We proceeded to observation in order to fix upon the spot on steep Rock Creek where we should begin. On Londay 6 th september 1779 having agreed with the Carolina Gentlemen in Observation; the following Memorandums were entered on their Journal as well as ours, as proper preliminaries agreed upon necessary for fixing this line, viz; "That the sun's Meridian Altitude was this day Fifty nine degrees fifty-two minutes,that this place of Observation was one finute and twenty-ilve seconds Norti of the proper latitude, or one lile two hundred poles and a half-- That at Steep Rock we were in superficial measure 329 Miles West of Carrituck Inlet;- That there should be an Abatement of twelve Miles for mountaineous and uneven ground, or that we were 317 Miles or five degrees forty two Minutes West of Carrituck Inlet, that a degree of Longitude in this Latitude was 4823 geographic Hiles or of statuate Miles 55 and 1083 yards. That Carrituck Inlet was in $75^{\circ} 30^{\prime}$ West Longitude, this being the average of three different accounts, and of course that the Longltude we were then in was $81^{\circ}$ $12^{\prime}$ West of London." We measured off the one $\mathrm{Mile}$ and $20 \mathrm{t}$ poles and a due south course, and the beginning of the line was thus fixed to the satisfaction of all. We should not have troubled you with these particulars, but for some subsequent events winich make us think it our duty. After running the line as far as Carter's valley 45 - Hiles West of Steep Rock Creek the Carolina Gentlemen concelved the Line was farther south than it ought to be, and on trial, it was found that the Varlation of the Needle had altered a little, which 
must have happened very lately, and was owing, we believe, to our being just then near some Iron Ure; because on observing the sun's Meridian Altitude the line was not to far south. As the Carolina Gentlemen, by their ubservations, made out otherwise, they proposed that the surveyors, on each side, should observe and fix the Latitude. This was agreed to by one of us, influenced by a knowled oe of a small Change of the variation and was not dissented to by the other, as most of the Observations on the part of Virginia had been made by him. But quite contrary to our expectations, they agreed we were more than two Miles to far south of the proper watitude, which distance was neasured off directly North, and the line ran Eastward from that place by two of the Carolina Gentlemen and one of us, while from the same place it was continued Westwardly, superintended by the others for the sake of expediting the business.

The instruments proper for ascertaining the watitude, were mostly taken back on the eastern part of the line, in order that those who superintend it might be farther satisfied; but after going back more than twenty miles, and observing every day on this line, his judgment was unalterably fixed that this line was wrong although the Carolina Gentlemen could not seem to be of this opinion, and he returned and overtook his Colleague on the Western part of the Line on Black Water creek or thereabouts, to whom he imparted his sentiments, proposing that he also should observe for sone days-which he did. The result was that we concluded our first right, and we brought it up accordingly from Carter's valley where it had been left and continued on with it to the Westward.

It was once after this proposed by us, and agreed to by the Carolina Gentlenen, that as we differed so much in Jbservation we would each run his own line, encamp as near together as we could and let future observers, hereafter to be appointed, determine which 
was right; which might be done at a small expense. But this they afterwards declined altho' they carried their line as far as cumberlanid

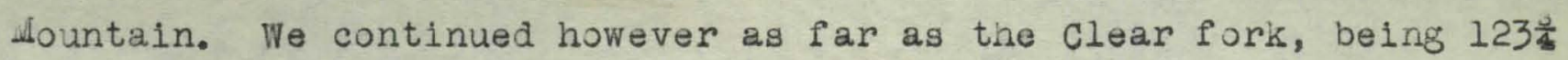
Miles from Steep Rock Creek, marking a Polar and two Hackberry trees with the Initials of our names and with November 22d 1779 and had serious thoughts of going no further. But when we considered that, perhaps, three fourths of the whole expense was already incursed, that a number of People were to the Westward, who imagined they were in North Carolina, while we thought they were on the Lands reserved for our Officers and Soldiers;- These and some more of the like considerations, made us think it more conducive to the good of the state in general that we should keep on, than that we should return. But as the season was far advanced, and the country before us, as far as it was known, was very Hountainous and barren, not yleldins a sufficient quantity of cane for our pack Horses, which for some time had been their principal support; these among other reasons, made us judge it best to leave off running the line here, and go farther to the Westward, into a better country, where by reason of nany People being about to settle, it might be of importance to run the line speedily. The map will show our rout to a place on Cumberland River, where we built Canoes to carry our Luggage and rest the Pack Horses, which were to much reduced to do service tinat way. And here to add to the number of our difficulties and misfortunes we were froze up more than forty days in a River never known to be frozen before. We went by Water from this place until we got into the proper Latitude (as we Judgeone hundred and nine miles West of the clear Fork) and began the Iine on two Beech trees marked with out names and Feb'y 251785 , on the West Bank of Cumberland River, a Creek coming in about a wile above us on the West side and another one some what sinalier about half a Nile below us on the East side. From this place we extended 
the line across the Heads of Green River, and Red River, through a Country called the Ba rrens from there being little or no tirber in it, in many places: crossed the Cumberland again at 131 Miles, where there is a clift on the North East side, and a bottom about three quarters of a mile broad the other side, and at the end of one hundred and forty miles one quarter and eight poles from the two Beech trees, on the twenty third day of March found ourselves on the Bank of the Tennessee River, and of coirse had run the line as far Westward as we were authorized to do, notwithstanding the Hardships and difficulties we had to contend with,-One of us kept through the woods with the Surveyor, while the other went down by water, by which means a tolerable Hap of the Cumberland River is taken; a fine River being navigabe at least 700 files from the mouth upwards. When we had returned homewards about 160 iles we met with orders from his Exceliency, the Governor to do another piece of service, which we suppose he has made you acquainted with.

We have also since seen Co. Henderson one of the North Carolina Commissioners, who with another of his Colleagues has been examining our line, and he has repeatedly given us much reason to believe their state will accept the line as we ran it.

\section{Thomas Walker}

From a paper, filed in the clerk's office of the House of Delegates among the Governor's Communications, 1780. Henning's Laws of Virginia, Vol 9 pp 502

\section{Appendix 7}

Journal of General Daniel Smith, Aug 1779 to July 1780. Running line between North Carolina and Virginia--Tennessee and Kentucky. Title by Draper.

Draper M.S. $40 \mathrm{~J} .18$

Saturday, Augt. 14 th 1779. Having for a few days been masing ready to go out with the Commissioners of the bine between this (state) and 
North Carolina as a Surveyor of the same according to my former agreement with Dor. Walker, this day $I$ sat off and reached the $E l k$ Garden 26 The Elk-Garden was a fort on cedar creek which flows in to th the Clinch.

Sunday 15th. Got to Dysorts where I met with Dor. Walker who acquainted me that I was appointed a commissioner in the room of wr. Jas. ifadison. 27

27. Probably the Jas. Madison who was later a bishop. He was a cousin of the statesman and president. Londay 16th. Got my Ball \& socket mended at Andr. Kinkennon's. Tuesday 17th. Went to court, and lodged at Hr. Willoughby's. Wednesday 18th. Went to John Key's on the Laurel Fork, ${ }^{28}$ being the nearest house to our place of beginning that we knew of. 28 a branch of the south fork of the Holston.

T hursday 19th. Rain last night, and to-day--Ra1s 'd the River so that we could not travel till $\mathbb{~}$ Monday 23rd. Hoved to a Camp on Col. Donelson's Line 29. about 7 ules west of the White topp'd mountain 20. 29 Col. Donelson ran eastern boundary line Cherokee Treaty of Lochaber 30. Haywood,pp 54 claims Va., had a cherokee Treaty (1772) for boundary running west from White Top it. on $36,30^{\prime}$ no contemporary evidence.

Tuesday 24th. Having from some accounts oflate together with Col. Fry's and Jefferson's map of the line, got an opinion that Col. Donelson did not begin where Fry de Jefferson left off today I went towards Donekon's beginning to endeavor to trace up the oid line taking with me Jas. Wichie one of the Surveyors. When I got within about a mile of the same found the old line and began to trace it up. lay in the Lountains which divi le New River waters from Holston. Wednesday 25th. got back to camp. Thursday 26th. this morning the distance Col Donelson's line was 
P 2. Smith Jour.

south of the old one was measured along a line making a right angle with the old one--52 poles. The course of the old line by compass not allowing for variation was $w$. $8830^{\prime} \mathrm{W}$. the distance was neasured along a course S. $1^{\circ} 30^{\prime} \mathrm{w}$. This day we moved to Tooley's river and encamp'd just above the little flag, meadow, south of the line about a mile.

Friday 27th. Wovei to a Waste Cabin on Steep Rock Cr. 31 about three quarters of a mile North of the place where the line would strike out. The creek to which Fry and Jefferson had carried the line. S aturday 28th. This morning Ur. Hichie came to camp with out ever having seen the line since he parted from us yesterday altho' he had carefully continued the same course.

Sunday 29th. a Number of us went and searched about the creek near the place $\mathbb{H}_{\text {r. }}$ Michie struck it for the line and could not find it, al tho' the place seemed by the Indian Camp \&c. to be the place where the old line struck 1 t.

Monday $30 \mathrm{th}$. this evening went to the top of a mountain, eastward to adjust the quadrout and take the Variation of the needle-- it look'd likely for rain, and I came back to camp. Rain all night. Tuesday 31st. lay still waiting for the Carolina Commissioners. Wednesday lst sept. This morning Hajor $\mathbb{W}^{\underline{1}}$. Bailey Smith a Comnissioner from Carolina came to our Camp, and this evening Col. John William and Col. Richard fienderson the other Commissioners joined. Thursday 2d. Sept. Proposed to the Carolina $G_{e} n t$. to go back to where we knew the old line was and trace it up. They said they would give us an answer next morning.

Friday.3d. They told us that as to keep in Latitude 36'30'' (sie) was the main object, thought 1 t better to go and search for the line, there take the Latitude if we found it, if right to run the west line at that place, if we could not find it, it would be best to got to 
3 Smith's Journal.

some mountain proper for Observation and by that run from the place of observation North or south till we were right, this was agreed to. $\mathrm{S}$ aturday 4th. Went to the Top of a wountain south westerly from our camp about 6 miles.

Sunday 5th. Observed by my instrument the Sun's meridian altitude to be $60^{\prime \prime}$ 14. after makins the proper deduction de ior refraction, Declination \&c. the latitude we were in was $36^{\circ} 31^{\prime} 25^{\prime \prime}$.

Honday 6th. Today the Sun's Aeridian altitude was by my Instrument $59^{\circ} 52^{\prime}$, which made the latitude exactly the same with yesterday their instrument likewise agreed with ours, therefore we were agreed we were 1 ' 25 " North of the line which when we reduced into superficial

measure we made 1 Mile 201 poles and on half. we agreed that we were here in longltude $81012^{\prime}$ West of London. That Cape Henry was $75^{\circ} 27^{\prime} 20^{\prime \prime}$ West of London, that Curratuck Inlet was $75^{\circ} 30^{\prime}$ West of London. That in superficial measure we were at steep rock creek 329 miles west of Curratuck Inlet, we made an abatement for dountainous grounds and uneven measure of 12 miles to this place or that we were 317 miles West of Curratuck lnlet and this place to be $5^{\circ} 42^{\prime}$ a degree of longitude in this Latitude 48.23 Ge: miles or of $s$ tatute miles 55 \& 1083 yards 32 . This evening by a magnetic line $52030^{\prime}$ E. the above distance of 1 mile and $201 \frac{1}{2}$ poles was measured. 32. substantially repeated in Va. Com. report

Tuesday 7 th. 14 poles more than the 1 mile \& $201 \frac{1}{2}$ po. was measured on the south line from that place we began the marked line by running $\mathrm{N}$. $88 \mathrm{E}$ on their compass to steep rock $\mathrm{Cr} .2 \mathrm{po}$. thence from the place we first began to measure on their compass $\mathrm{S} 88 \mathrm{~W}$ (blank in $\mathrm{I}_{\mathrm{s} .}$ ) po to the top of a spur. here Col Henderson and my self went to them having settled the Bar; at 3 degrees $E$ on my Compass \& $2 \frac{1}{2}$ on theirs, and directed the surveyors to make this allowance. Vid. plat of steep Rock Cr. for the place of Beg8.33 
33 This may refer to some specia plat but more probable this and a later reference to a "plat" are to be considered as referring to the map.

Wednesday 8th. The latitude being settled, and the Surveyors set property to (work) it was thought I might go home for a few days without Injury to the Service, and I accordingly sat off. Lay this night at Mr. Lagans-- lotst my Horse, but got home on Thursday on a Borrowed one which I returned on S aturday. S tay'd at rome till. Wonday 13th; Sat off in the rain, lay at $T$. Price's Tuesday 14th North fork $H(i g h)$ but got across it and lay at Wr. Tinley's. Wednesday 15th, got to the Surveyors about one J'clock where I was informed the Carjlina Gentlemen had concelved an opinion we were to far to the south of the true $\mathrm{L}(\mathrm{at})$. Wuch cloudy weather this week. After many Jbservations, we concluded we were rigit and I sat off Wednesday 22d. for the Island ${ }^{34}$ where I had re ason to belleve Dor. Walker was waiting with as much impatience with a Party of the cheroke Indians as I had been the last week. way at Cornelius cormacks, Thurday 23d. lay at Col. Shelbys who promised to go to the Island with me next day. 24th Sept Friday., Got to the Island wet with Cajt wosten in ay way there at Wajor Bledsoes 35 . At the Island Dor. Walcer informed me that this day he \& Aajor $w$. Smith had given the Indian the following Talk. Blank page in M. S.

34. The tong Island of Holston famous as the place for "peacetalks" with the Cherokee.

35. Anthony Bledsoe $1733,1738,71-78$ member of Va. Assembly. Settled at Bledsoe's wick upon the Cumberland in 1784. Saturday sept 25 th The old Tassell 36 replied as follows. Now I am come to the place appointed by my beloved fan to listen to the Talks of the beloved wen of Virginia-- Here are both the commiss. I speak to (meaning the commiss of both states) now are on the beloved 
seats you shall hear what I have to say. Those on the beloved seats where we've held the good Talks and saved the lives of so nany of our pedple on both sides, this now three days(meaning jears) since these grod talks were first held. When we first came from chota 37 the way was very dark and troublesome but it was his and bad people that occasioned it to be so, and caused trouble between us like wading thro' blood it was when I open'd the Way, and the Doors of Peace and brightened the Chain of friendship between us and our elder brothers. I am the man that opened the Doors of Peace when they were fast shut that caused the light to shine from each one to the other, and ours and our elder brothers people to remain in peace. I've only been talking of the Peace between us and our friend and elder brother that sits here (meaning Col. Shelby) 38 who was one of the appointed Commissioners at that time, as they both must remenber well that everything which passed before that being bad was thrown away not to be brought into rememberance anymore, in so much that where the dead men lay they were buried so deep that large trees had grown out of their graves-- That the beloved Man of Virginia and him of chota talked together stretc'd the chain of friendship from Virga. to Chota, and appointed Commissioners that if any rust should get thereon tirey and the beloved men of chota might brighten it so that as their children came to any knowledge of things it might be a guide to them and had in remembrance for ages yet to come, and as for my own part I will always be assisting in keeping this chain bright. I speak to the commissioners of both States--I of ten times talk from home that the Governor of $N$. C. nay hear me, but I belleve what I say never reaches his Ears. I as of ten speak to the Gov. of Virginia who I believe hears, and I hope both will hear what I've now said.

A string to the com. of both states. You spose to ne yesterday concerning the dividing wine between you 
which you left me to consider on till to day. I do not know how for you mean to extend 1t. Hy hunting grounds and my Lands reaches to Cumberland river-- You have your livings at your Doors, tis not the Case with me, I am oblidged to slave hard and go a great way to get a support for myself and children, my hunting grounds extends to the Cumberland River, quite to the mouth of it on the south sede, which is but a little place to support so great a number of people as are in my nation. I mention my people as I expect some of them are on their way for Cumberland there to make their Hunt. I am uneasy to get home to prevent any more from going, for if the line is extended thro' that Country you must fall in with soine of them--moreover if it should pass thro' there and cut off any part of our hunts grounds 'twill make me begin to think of what I was told some years ago by the rings people $1, e$, if our elder brothers here overcome them, they would at last take all our hunting grounds and bring us to nothing. But I hope this will not be the case, and that our elder brothers will have more compassion for us. wast Spring Hanging Man was sent by the great Warrior of chota and talked with Col. Shelby and dajor Martin concerning 8 Jds, which I understand by what he told me on his return they would use their best endeavors to supply us with-- now you see the necessity we are in you see we are almost naked, and 'tis only by holding our elder brothers by the hand. We hope you will consider us and try to send us a supply as soon as rossible. I speak this to both states. uur concerns with N. C. has always been respecting Lands, we have never seen any supplies from them jet, but $\perp$ hope the concerns of Lands will soon be at an end, then we expect they wiL consider us and send us some cloathing as we $1 \perp$ as the other states-- They by their commissioners moved the beloved seats from over the river to this place, here they kindled the beloved fire, and reserved the wood, the grass and the earth of this Island for our purpose, to hold good taliks upon with our elder brothers, now I hear 
there is some man lays claim to it, altho' the beloved men of the two states have reserved it for us. I speak to the com. of both states 'tis 3 days since we held the good talks at this Place, and then with the Comm: of N.C. we fixed a boundary between us and their people which was to begin on this river where the Virga. line did and run thence by the Chimney Top to the mouth of Camp Cr. on Sonachucka. Mr. English is settled over that line on a good place which we are not much of lended at as we belleve him to be a good man, but a great many others are settled for beyond him which must of course known they are over the line. Car: has gained a great deal of ground of us for which we have never rec'd any satisfaction no not even so much as trade. The great men in Car: seem to hold everything very fast in their hands, they are always getting what they can, and lets nothing go, neither guns, goods nor ammunition.

A String to both Commissioners.

36. The Jld Tasse11, or Anyetaeh, of Toquoe, was one of the signs on the part, of overhill Ch. of tile treaty known as Avery's Treaty, made at the Long Island of Holston July 20, 1777, During the troubles of State of Franklin he was killed under circumstances of great cruelty-This in 1788.

37.

A "city of refuge" of the Cherokees on Telilco River five miles above old Fort wondon.

38 Evan Shelby. 1750-1826 This reference to Treaty of Holston in 1776. Sunday 26th. Col. Henderson made a speech which they did not seem to like very well.

Ionday 27 th sept. We spoke to them as follows:

Brothers, Chlefs and Warriors of the Cherokee Nation. We are very glad to meet $y$ u our brothers and friends at this place, where we before have had so many good talks to smoke the pipe of peace 
together and keep that chain of friendship clear from every speek of rust which we ourselves and we hope our children for ages yet to come shall feel the good effects of.

But it gives us some concern to find that our Intention in running the dividing line should be look'd upon by you as a matter that will be to your prejudice, as we have no intention of doing anytining with you our brothers, but what will have a tendency to brighten the great chain of friendship which we have fast hold of much less to do anytinin 8 which is a real injury to you. As we did not conceive that this line would be any wise prejudicial to you so our only reason for acquainting you there with was lest reports by evil minded persons should be carried to you misrepresenting the matier as the best intentions have sometimes been so construed. Now brothers we beg of you to listen well to what we are goins to say. You told us the other day that our living was at our doors, but you had far to 80 and slave hard to support your people, we would recommend it to you to live as do and only hunt for neat and skins to make your moccasins, ralse corn and cattle horses and hogs and sell them to cloath your wives and Children which you will find much surer and easier than your present manner of life.

We are sorry to see and hear your people are so naked, the great men of Virga. ordered Clothes for you from the Illinois which we expected would soon be here, but we are told the people of Chickamogga and Chickasows will not let them come up this river, therefore we shall write to the great men by Your Shelby and your brother Martin 39 will speak to them to send you goods from Virga, we are sorry the goods are not here to give you some clothes to return to your towns with but the fault is in your enemies therefore hope you will not blame us as we are not in fault.

You told us you hoped Virga. would not take away your Land, we can 
Assure you Virga. will not take any Land you have a right to. Your beloved Island on which we now stand Virga. had secured to you by law if it fallen in that state, and we make no doubt as it falls into Carolina but the great men there will reserve it for you. Hold fast the chain of friendship with Virga. and the Virginians will never let it slip out of their hands. The people over the water we believe will soon make peace with us and then we shall be able to give you a plentiful traje.

As a Token \&c. we give yu this String of Wampum, 39 Joseph Martin Indian, agent of Virginia.

Tuesday 28th sept. moved to the Camp at the Millstone Quarry about 200 Yds in Virga.

Wednesday 29 th took Latitude we believe the line is about half a mile too far North, corroforated by another Ubserv.

Thursday 30th. lay still waiting for the Car:40 who were not ready with their Provisions. 40 Carolinians.

Friday 1st. Oct. Rain--but sat of in it to go to the Carolinians, only got to the Surveyors Camp on the S.E. gide of the north fork of Holston. Saturday 2d. Jetr. Being consclous from what in fornation we had obtained that a Sufficient Guard could not be had on the Virga. Side, for the pay allowed by Law, because the Carolinians gave at least seventines as much pay, and being further informed that if we would maze a requisition of men from the Caro: Com: they would furnish them, and put them under the Virga. Comnander only leaving the matter to the two Assemblies to settle, this day we nade the demands of fifty men on the sald Terms. Hoved down Carter's valley 41 and encamp'd about 2 m. east of a fort. 41 North of the Holston and west of the north fork of that river. Sunday 3d oct. lay still. Nonday 4 th do.

By Observations at this Camp made till Sunday loth it was made out by $M r$. Burton and Mr. Guthrie 42 we were $2^{\prime} 10^{\prime \prime}$ to far south, and 
Monday 11th, we began to measure off the distance on a north Course. We had also observ'd that the Var: was lessened which possibly might have caused the error. Tuesday 12th Rain--lay all night on a branch of rossum Cr.--Wednesday 13 th began to run back the East Course in Company with Col. Willians while Dor. Walker and Col. Henderson run on West.--lay on a spring branch 2 miles a about a Quarter $\mathrm{E}$ ast of the termination of the $\mathbb{N}$. 1ine. 42 The North Carolina survejors. Thursday 14th. got to where the Kentucky Waggon Road (43) cross 'd the North fork of Holston, did not find the Surveyor to-night.

43 The Wilderness Road.

Friday 13th Went to the Block House--The Surveyor came there about $10^{\prime} \mathrm{Clock}$, then went to a branch about $1 \frac{1}{2}$ miles eastwardy from Block House \& lay all night.

Saturday 16th. While the Line kept on took the watetude on a snob about $\frac{1}{m} \mathrm{~m}$. south of the Line, The Double alt. of Sun $89^{\circ} 0^{\prime} 30^{\prime \prime} 80 \mathrm{t}$ to $\mathrm{Abm}$. Bledsoes 44

Brother of Anthony.

Sunday 17th. Jbserv'd again at Abm. Bledsoes, here we were in Lat. $36^{\circ} 31^{\prime} 40^{\prime \prime} \mathrm{N}$.

Monday 18th Jbserved in Robts. Hillpond dble Alt. $87036^{\prime}$. Lajor Smiths was $87^{\circ} 42$. This Flace is 600 or 700 Yds in Carolina by the first line and my observation nearly proved the sd. line right.

19th. on a xnob about mile so th of the new line observ'd again dble. Alt. $86^{\circ} 46^{\prime}$ wajor Smith's $87^{\circ} 12$. 2oth in a Plantation about mile North of the line observ'd again dble Alt. $86^{\circ} 3^{\prime} 30^{\prime \prime}$ Major Smith's $86^{\circ} 14^{\prime}$. Went to wajor Bledsoe's 2lst took the wat. here Dble alt $85^{\circ} 22^{\prime}$.

22nd Measured the Distance the two lines were apart, it was 838 po. 23d Rain all day, lay still. 
24th. took the Lat. again-- Dble, Alt. $83^{\circ} 17^{\prime}$. here I was about $\frac{1}{2}$ mile North of the first ine. All these Observations made out that the new line was wrong and that old one was nearly right. And I came to this Conclusion, that either I did not see as others usually do, or that the first line was right. I found there was no dependence to be placed in Najor Smith's Jbservations, who as will appear above frequently made us from 4 to 8 or 9 miles off the Line. I resolved therefore to go back to Mr. Walker let him take the wat. If hig Jbserv. made the new line right I would be convinced I did not see fike other people. If on the contrary they should agree with mine I would be for correcting the line. Got this night to Abm. Bledsoes. Lond. 23 th Went by Col. Henderson's Camp in Carters valley, delivered him his quadrant which had been entrusted to my Care, and which I had forgot to mention, I had discovered at Major Bledsoe's to make the Sun's Alt. less than ours. told him 1 could not make an observation to prove the last line right, on the contrary, they always proved the first to be so. This he sald he was surprised at. Lay at John Loonys. Tuesday. 20th Jvertook Dor. Walker on the North fork of Clinch, told him my Sentiments

Wednesday $27 \mathrm{th}$ Dor. Walker to the Lat. We were 50 scouts (seconds) in Virga. altho considerably south of the Line. lost Horses, could not travel till

Thursday 28th got to a Lick on Black Water.

Friday 29th Saturday $20 \operatorname{th}(30$ th) and Sunday 31st. all these days Dor. Walker observd and his observations made us at least 42 seconds in Virga. this was the lowest observ. the highest $1^{\prime} 20$ " altho' near a mile south of the line. woote to Col. Henderson who had not yettjoined us that we were satisfied the first line was right and that if his observ. had been the same with ours to have it brought up. 54 Londay lst. Novem. this afternoon col. Henderson came to us. 
Tuesday 2d. Dor. Walker \& Col. Henderson went to the top of the anob and observed.

Wednesday 3d Nov. Dor. Walzer observed with their Instrument on the line which he made 4 miles to far north. Thursday 4th, sent of $4 r$. Michie to bring up the ilrst line. Mr. Burton observed with their Instrument and nearly agreed with Dor. Walker.

Friday 5th. 4r. Burton \& Mr. Guthrie observed as they did in Carters Valley, $100 k^{\prime} d$ at $4 r$. Go. Instrument, and found what $\perp$ suspected that the reflection sun was too low. began to neasure of the Distance southwardly to keep on the line.

Saturday oth. finished measuring the line to the south, and started Capt. Burton from the 09 mile we asreed to meet him near Cum: Gap 45 then cross'd rowells Mount 46 went by our camp and lay at the car. 45 Cumberland Gap. 40 rowell's Nountain and rowell's River, the ridge and the tributory of the clinch just east of cumberland wountain Henderson's wetter to Governor Caswe 11, Introduced here.

Sunday.7th. Went back to our Camp on bus 47 returned $\&$ lay on rowell's River. 47 (Business)

Alonday 8th. Col. Henderson proposed sending his Brother's or capt. Hardin Co, we told him any that would do the duty we would be satisfied with lay about 3 miles west of Martins.

Tuesday 9th. Got to a branch about 2 miles E. of Cum: Gap. Wednesday-- Made us a large Sixtant to observe with. Thursday 11 th lay still. Surveyors not come yet. Capt. Hardin's Company Joind us.

Friday 12th. Mr. Michie came to us. Jur observ, at this place were that we were 2 miles in Virga. Capt. Burton came to us this evening. Saturday 13th. Got Ar. Anderson to act as surveyor, moved over 
Cum. wount, lay on flat $\mathrm{Cr}$.

Sunday 14th. way st111. Sent Capt. Bledsoe 48 to explore the country. 48 Isaac Bledsje brother of Anthony and Abram. Monday 15 th wat. $36^{\circ} 32^{\prime} 50^{\prime \prime} \mathrm{N}$. Capt. Bledsoe return'd, from his account concluded it best to so along the kentucky road, march'd about 4 miles lay on flat Cr. Capt. Anderson came to us in the night. not having met with the Escort sent him in consequence of some Funters having fallen in with and killed some Indians.

Tuesday 16th. While we were on our march received an extraordinary Letter from the N. Carolina Comissioners, with drawing Capt. Hardin's Company from our service and discharging him.-- lay in the south edje of the bottom just below the ford of the cumberland.

Wednesday 17th. Nov. way here till after 12 . Took wat. walch was $36^{\circ}$ $41^{\prime} 58^{\prime \prime}--m a r c h ' d$ on to a small cr. about S.W.

Thursday. 18th. Warch'd about s.W. fior 8 miles along a brozen valley at the foot of stone mountain. encamped on a coms Cr. Friday 19th. Held on our course up to the cr. \& about at the head of 1 , fell on two other Branches which we kept up and out at their heads. lay on a Cr. that Ran directly into the clear fork about 4 or 5 miles from the mouth thereof.

Saturday 2uth. Got to the clear fork ${ }^{49}$ and encamp'd on the N.E. bank just below the mouth of a small gut, about a mile above the mouth of the cr. we came down, a rocky clift belng about mile above us lon the other side of the riverl which faced to the north.

49. Une of the headwaters of the cumberland.

Sunday 2lst. This morning a party of cherokee Indians and a White man of the name of springstone came to us, about 1 or 2 oclock capt. Anderson and his party all came safe to us. wonday 22d. Novr. Here a very mutinous spirit began to appear among the Guard owing to our continuing the line thro' such a mountainous 
14

desart and we thought it most rrudent to run the line to the Clear Fork, then turn to the North into the Eentucky road and down the North side of Cumberland to the Valuable Country and there proceed on with it. We began to pursue this plan the line strikes the clear fork about $\frac{1}{2}$ mile above the mouth of the little $\mathrm{Cr}$. In a cane broke on a poplar $\&$ 2 Hackberry trees marked with the inttial letters of several names measuring from steep Rock Cr. 123 miles 30 this day after quitting the line went by the Indian Camp and got three of them to go along witn us, Lay on the E. side the river $/$ or $8 \mathrm{~m}$. Took the wat. Where the line gtrikes river tis $30^{\prime \prime} 30^{\prime \prime}$

5u. unce after words proposed to and agreed by N. C. com. that each run his own line.

Tuesday 23a. Cross a the river traveled about 5 or six miles lay on $w$. side.

Wednesday 24th. Kept down river cross'd Cun: below the mo: of clear fork. Lay in bottom on N. Side. Cloudy and a little rain $b$ or o miles. Thursday $2 b$ th. Cloudy. travelied across from the river to $\perp$ ndian cr. then up, the Cr. N. Easterly about 0 or $/ \mathrm{m}$. Snow to night. Friday 20th. Lay still, all day took lat. tis $30^{\circ} 47^{\prime} 10^{\prime \prime}$. Saturday 2/th Nov. 1/19. Removed from Indian Cr. N. E.ward b or o mile and encamp'd on Lynn Camp Cr. a branch of waurel River bl Cloudy and like for rain to night. 51 The nex tributory of the Cumberland, considerable north of clear Fork. Sunday 28th. - isty and some rain with thick Clouds. today capt. Craig's Company were told that in consequence of what had been promised them heretofore (especially at Clear fork) we now were ready to discnarje part of them, or a 11 a ove 15 Which at length they furnish'd us. rain to night.

Monday 29th. Rainy lay st1ll. Major Bledsoe was settling his Accounts. Tuesday Sutn. To day Capt. Cralf and sundry of his nen, and also the 
15

Surgeon let't us--Rainy.

pp $3 \%$

Wednesday Lst. Decr. Cloudy travelied N.E. about $b$ miles encamp'd on anouner branch of Lynn Camp Cr.--

Thursday 2d. Decr. Windy and showers of Snow latter part or tne day

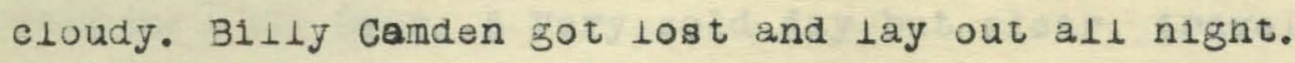

Firday 3d. While $\perp$ went up to the Aentucky road Lookins the lost man Ar. Walker took the Lat. of this camp uls $30^{\circ} \mathrm{b} 3^{\circ}$. B11Ly Camden came in. We prepared to make an early start tomor row morning.

Saturday 4th. Woved into the kentucky road and along it to waurel River encamp'd about a mile a sove the road. Snow to-night. Sunday 5th. Snowing lay still. Monday 6th cloudy lay still. Tuesday 7 th March'd to the first creek of Rockcastle ${ }^{52}$ 52. A still more northern branch of the cumberland River. Col. Henderson was encamp'd we were told about a half a mile below us. Wednesday 8th. This morning col. Henderson paid us a visit. moved near Rock Castle encampd on a Cr. Which we called Bever Cr. Thursday 9th. Cross'd Rock castle \& left the rentucky road, encamp'd on the river about 4 mile below where the sentucky road leaves it. a liard wind to-night.

Friday 10th. lay still, waiting for Hajor Bledsoe to come up, who had been left where we saw Col. Henderson, looking lost Horses, took the latitude of this rlace 'tis $37^{\circ} 13^{\prime}$ not sure the Inst. right adjusted. To night wajor Bledsoe came up.

Saturday 1lth. Travelled about 8 miles, tho perhaps not more than 5 on a right line, our general course about West. lay near the head of a branch of Rock Castle at a small Canebreak. Rain to night. Sunday 12th. Wuch rain to day. all day lay still. wonday 13th. Cloudy and some showers of snow. After $12 \mathrm{~J}^{\prime} \mathrm{Clock}$ the creak not suiting our course from this Camp we travelled along a ridge nearly West t11l we came to a Branch of Buck $\mathrm{Cr} .{ }^{33}$ which we kept down 
16

till after the Sunk, this evening we fell on a Trace that we suppose led to the french Hick, encamp'd on it. A cold night, our days march 6 m. 53 A stream west of Rock Castle. Smith's route was now turning towards the west.

Tuesday 14th Decr. A Very cold day but clear, travelled along the Trace N. Westerly about $2 \mathrm{~m}$ to buck $\mathrm{Cr}$. Which too highto ford lay at it all day. an excessive cold night. 54

54 This winter was long remembered for its extreme cold. Wednesday 15th. Cold and Cloudy. Travelled up Buck Cr. about 1 mile on the E. side by which we missed two crossings of the cr. then we cross' $d$ it and travelied along the Trace a little to the $S$ outhward of west, crossed another fork of Buck cr. at a lick, up a branch and out at the head thereof, then down a branch of rittman's cr. encampd at the first cane thereon. A lattle snow to-night. $8 \mathrm{~m}$ to day. Thursday 10th. went down the $\mathrm{cr}$. by myself about $2 \frac{1}{2} \mathrm{~m}$. found Pittman's and several other families encamp'd there, went back to camp lay still all day.

Friday 17th. Went down Fittman's cr. cross'd it several times, tien at last left it and travelled across to Fishing $\mathrm{Cr}$ : which we struck about $5 \mathrm{~m}$. above the mouth. lay on a small branch at the mouth. Misty all day. $12 \mathrm{~m}$ to day.

Saturday 18th. lay still, went down $\mathrm{Cr}$. to find the river (Cumberland) I did not go for enough, killd a buffaloe \& return'd. Wr. Wichie took Lat. 'tis $36^{\circ} 38^{\prime}$

Sunday 19th. march'd down the $\mathrm{cr}$. nearly South about $5 \mathrm{~m}$. to the river then about W.S.W., 1 m. down the river, and encamp'd, Lat of this place on an accurate obsr. $36^{\circ} 34^{\prime} 42^{\prime \prime}$. Dble. Alt. ver.ob.59 $19^{\prime}$. Aonday 20th. Major Bledsoe went to look for Trees to build canoes and go down by water in pursuance of a resolution which we took at Laurel River, having return'd and found them. next day Tuesday 21st. we march' 
down the river about 5 miles to the rlace.

Wednesday 22d. Set about the Canoes, Mr. Michie took Lat. 'tis $36^{\circ} 51^{\prime} 31^{\prime \prime}$ Thyrsday $23 \mathrm{~d}$. I took the Lat. Neridian dble. alt. $59^{\circ} 22^{\prime}$ ver. ob: Lat.

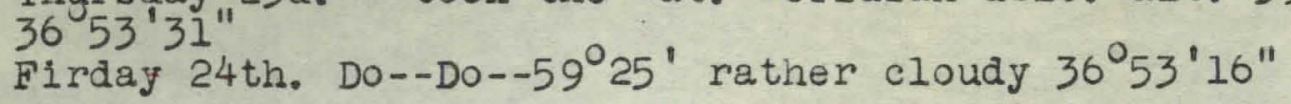

Saturday $25 \mathrm{th}$. Christma Day. Do. Do. $59^{\circ} 27^{\prime}$ ver. ob. $36^{\circ} 53^{\prime} 16^{\prime \prime}$.

Sunday $20 \mathrm{th}$. No work on canoes these days.

Monday 2/th. Working on Canoes. Cloudy s misty on little rain.

Tuesday 28th. Do Do.

Wednesday.29th. Saw the sun a little tho not enough to take a good observation.

Thursday. 3uth Cloudy \& a little snow.

Friday 31st. Clear \& Cool. Ar. Walker tsok Lat. ver: ob. dbie. alt. $60^{0} 3$ Lat. 30.53.58. discoursed a little witn $w^{\mathrm{m}}$ Young wno just came from $\mathrm{Ky}$.

Saturday. Jany 1st 1780 Launched one of the Canoes. Jerry rearce came over irom frices \& Lay with us to night. Snow to night.

Sunday $2 d$ Thro. seareity of me at went down by water a hunting with 2 others. Cloudy some snow. Lilled Turkies at night to live on. Lay $4 \mathrm{~m}$. below Station Camp 30 (36 name in Haywood. pp 92) Monday 3a. went about 3 miles lower killed a Buffaloes. Late before we got them butcher'd; clear a very cold night.

Tuesday 4th. moved up the river with two of our Buffaloes. The ice was so bad coming down the river we could only reach our sunday night camp where we lay with uba Terrel.

Wednesday bth. got back to Station Camp. but some how by accident got the britch of my gun broke off.

Thursday oth cold to such a degree tine river froze over, and continued froze over t111 Sunday 9th. Jany. 1/80 when wajor Bledsoe crossed over on it to go to prices. In this time 1 fixed up my gun Barr in on other stock $\propto$ Lock. 
Thursday. 13th. Went down the river a hunting in order that less provision might serve at our station Camp as inere was no appearance of a thaw. 1, M. F.W. Went with me, Lay at uba's camp. Friday 14th. Lay on tne Riv. $9 \mathrm{~m}$. Delow Station camp to 30 to tre nearest way killed two buffaloes.

Saturday 15th. killed another buffaloe. Nonday 17 th went alone back to

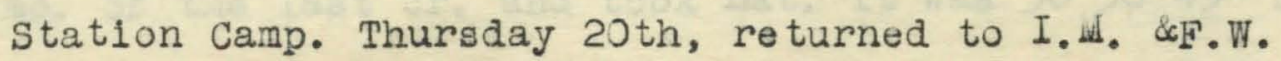

Friday 2lst. moved down the river $6 \mathrm{~m}$. lower killed 5 buffaloes. Thursday 27th. went back to station Camp. no appearance of a thaw yet stay'a here till

Honday 3lst Mr. Sharp went down the riv. with me. Monday 7 th Feby. Snow a little last night \& to day. Wednesday the weather had moderated a little Thursday loth Feby. An appearance of a thaw coming on. We went to Station camp, Rain to night a litle. Saturday 12th. Riv. rose much. Sunday 13th. This morning the Ice broke and we launch'd our canoe. Nonday 14th launched another Canoes. Tuesday 15th launched the other and sat off down the river lay about $1 \mathrm{~m}$. above our first encampinent. vid. plat. of viv. Wednesday 16th. at $39 \mathrm{~m}$. dist. by water from Canoe Camp passed by the mouth of a large $\mathrm{Cr}$. on the $\mathrm{s}$. Side at $57 \mathrm{~m}$. encamp'd at the foot of a large bottom on $\mathbb{N}$. side where the riv. run E. Just above the mouth of a small cr, where there was cattle left \& Mr. S harp lay from us. Thursday 17 th. at $72 \mathrm{~m}$. passed by a curious nat. bridge on $\mathrm{N}_{\text {. Side at }}$ $76 \mathrm{~m}$. encamp' $\mathrm{d}$ on $\mathrm{N}$. Side in a large bottom.

Friday 18th. at the mouth of Brushy Cr. found a note of Capt. Bledsoe's who had gone along with the horses. the wat of this place $36^{\circ} 42^{\prime} 46^{\prime \prime}$ and $91 \mathrm{~m}$. distant at $106 \mathrm{~m}$. pass'd by the mouth of a cr. on $\mathrm{N}$. Side another 
note from I. B. 57 at $117 \mathrm{~m}$, another er; on N. side with fresh Blazes where we encamp'd.

57. Isaac Bledsoe.

Saturday 19th. at $132 \mathrm{~m}$. Stopp'd on S. Side and $100 \mathrm{k}$ Lat. which was $36^{\circ} 34^{\prime} 51^{\prime \prime}$. at $147 \mathrm{~m}$. a $\mathrm{Cr}$ : on $\mathrm{N}$. Side at $149 \mathrm{~m}$. encamped on $\mathrm{N}_{\text {. Side. }}$ Sunday 20 th went up the bottom, supposing we were in Carolina, to the mo. of the last or. and took wat. it was $36^{\circ} 30^{\prime} 49^{\prime \prime} \mathrm{Dble}$. alt. $85^{\circ} 12^{\prime}$ measured some (down)298 po. to the supposed Line To day Major Bledsoe went in search of his brother.

Wonday 2lst. Major Bledsoe returned with his brother. Rain Tuesday 22d A wet kind of Snow, all day. Wednesday $23 d$ some snow. hunted this afternoon for Turkies.

Thursday 24th. Clear $3 c$ Cold, went to the place of Ubservation Dble. alt. $88^{\circ} 9^{\prime}$.

Firday 25th. Went again to the place of observation, and as our observations had never varied more than 19 seconds 1 ixid the line.-- to begin at a Beech on the top of the bank. The line crosses the river nearly at right angles ( 35 S.W.S.W.) bottom on both sides the river. mark'd our name and the date on the two Beeches, and also marked on the Eastern bank an east course from the Beech. Uur names on two Maple-lize trees and their Initials on a box elder, having done this the surveyor ran the line West to the top of the first hill \& A. creek comes in on the N.W. side about a mile above the line and a smalier one on S.E side about $\frac{1}{3}$ mile in Carolina 58

58 Reference to where they established the line.

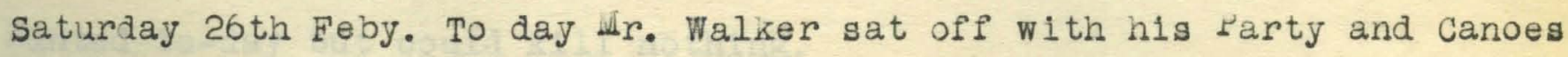
to secure provisions \&c. while I went with wr. Wichie un the line. We were to meet at the French $L i c k$ or in its neighborhood, at least 1 was to do so with the Quadrant, and Mr. Wichie is to run from where I shall leave him to where the line crosses cumberland again. Run 2 m \& 240 po. to a cr; at the wouth of which we had taken the wat: the line keeps 


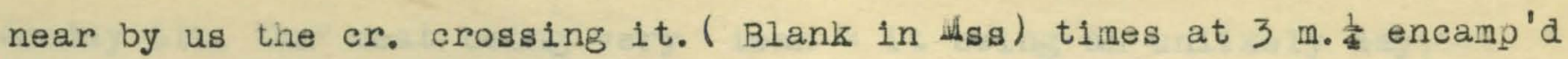
in $\mathrm{Cr}$ : bottom. about $\frac{4}{4} \mathrm{~m}$. above a north fork of it.

Sunday $27 \mathrm{th}$, at mid-day today took Lat. Iine right at $\left(\frac{1}{2} \mathrm{~m}\right.$. the top of the dividing of the waters between cumberland \& Green River.Vid. nap line-- at $14 \frac{4}{4} \mathrm{~m}$. encamp'd on a small br. running $\mathrm{s}$. into a $\mathrm{Cr}$. of Green R. 59

59. Probably a branch of Barren River, which runs into Green River. The latter empties into Uhio opposite Evansville indiana. Londay $28 \mathrm{th}$. at $16 \mathrm{~m}--6 \mathrm{po}$. Came to the $\mathrm{Cr}$. again, and being entirly w1 thout meat and having fasted some time went a hunting--killed two large Bull Buffaloes.

Tuesday 29th. Ran about $6 \mathrm{~m}$. to day. Rain in the Afternoon. Quitt the line at $22 \mathrm{~m} .--$ a $\mathrm{few} \mathrm{ch}$. and went down a branch that ran about $\mathrm{N} .70$ W. encamped on a cr: at the Wo. of sd. branch. rain. Wednesday lst farch. It did not clear up till near ten v'Clock, then fair, took Lat. found the line very right. Dble. Alt. $92^{\circ} 40$ at $23 \mathrm{~m}$. 00 po. cross'd cr: we camp'd on, cross'd a steep hill, at $23 \mathrm{~m} .104$ po. another cr.running near north--cross'd another hill, at $24 \mathrm{~m} .34$ po. another cr: these creeks we suppose come together and run into the one we came down first, at $27 \mathrm{~m} .152$ po. left line and went to the north about $\frac{1}{2} \mathrm{~m}$ : and camp'd on a $\mathrm{cr}$. Thursday 2d Warch. at $28 \mathrm{~m}$. 60 po. eross'd another cr; running N. then across some very briery ridges at $34 \mathrm{~m}$. 40 po. anotier $\mathrm{cr}$. running to N. on which we encamp'd. Friday 3d. at $38 \mathrm{~m}$. 240 po. a $\mathrm{cr}$ : on which we encamp'd--Newton's or: Hunted to-day but could kill nothing. Saturday 4 th. at $46 \mathrm{~m}$. 212 came to a cr. on which we encamped ,2 Buffaloes kill'd to day poor. Sunday $5 \mathrm{th}$. Rain this mornins a little, in the afternoon a good deal, lay still. 
Monday 6 th. Our meat being very lean \& it being an unlikely day, Capt. Bledsoe hunted--I stald at Camp in order if fair to take an Ubservation, which I did tis $30^{\circ} 30^{\prime} 15^{\prime \prime}$ Dble Alt $90^{\circ} 30^{\prime}$. As this observ was good I depend much on 1t. I discovered also as I thought that too little variation was allowed. Mem: observe to night-- Twas Cloudy about $90^{\prime} \mathrm{Clock}$, and hard rain afterwards till near day but when the pole star was in the most western part of his orbit it appeared there was, by taking his bearing, to be full six degrees, var. Tuesday 7 th. Run to day magnetically S. 84 w. at 504.478 . crossed a creek running $\mathbb{N}$. W. on which we killd a Buff. at $51 \frac{1}{4}$. got into the edge of the Barrens, at $55 \mathrm{~m}$. 242 po. a large cr. running near N. about 10 W. on which we encamp'd Took the Variation to night at sunget by her amplitude and also by the role star when on the meridian. I find it 70 Degrees E.

Wednesday Iarch 8th. a.t 64 m. 294 po. a Cr. whose gen: course seems N. W. tho' just where we cross'd it N.E. on the W. Side of which we encampd-Went hunting found the Cumberland Road ${ }^{60}$ about $\frac{1}{2}$ mile to the West. bo The road to the French Lick on the Cumberland River. Thursday 9 th at $66 \mathrm{~m} .14$ po. cross'd the cumberland road running W.S.W at $73 \mathrm{~m} 231$ po. a cr. on which we encamp'd. Took tat. to day. $36^{\circ} 29^{\prime} 52^{\prime \prime}$ Dble. alt. 98.51 .

March 10th. Oblidged to stop to hunt. Capt Bledsoe killed nothing but 2 Deer, took Lat. Iine very right. Dble. Alt. $99^{\circ} 39^{\prime} 30^{\prime \prime}$ Saturday 11 th. Today I sat of to the French Hick to meet Mr. Walker. Got into the Cumberland road and lay thereon on a small cr;of Red River 61-25 miles today.

61. Sulphur Fork, a branch of Red River rises E. Hy. road. Sunday 12, Got to Gaspor's i $^{6 \mathrm{ck}^{62}}$ Snow. Londay $13 \mathrm{ch}$ lay still. 62 Gaspor or Gaspor Hanice \& his explorations. Haywood pp 88. 
Tuesday 14th. Got to the French $\mathrm{Hick}$

63. The site of Nashville. No mention of James Robertson and settlers. Wednesday $15 \mathrm{th}$. Sat of to neet $\mathbf{M r}$. 4 ichie. Lat. at Eatons $36^{\circ} 7^{\prime \prime} 64$

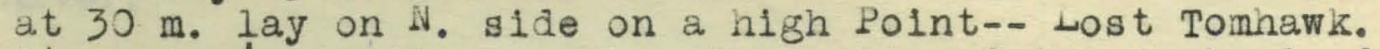
64 Easton's Station on the other side of the Cumberland. Thursday 16th. at $20 \frac{1}{2} \mathrm{~m}$. pass'd by the mouth of Harpers ${ }^{65}$ River in all $32 \frac{1}{2} \mathrm{~m}$. Ind. town.

65 Harpeth River. Haywood also spells it Harpers. Friday $17 \mathrm{th}$. only $11 \frac{1}{4} \mathrm{~m}$. to day, Ind town.

Saturday 18 th at $11 \frac{1}{4}$ took Lat. $30^{\prime} 21^{\prime} 22^{\prime \prime}$ at $12 \frac{\mathrm{ms}}{\mathrm{m}}$. of red river in all $36 \mathrm{~m}$. lay on high bottom Just below where(bur dog wounded stricien out in $\mathbb{M}_{\mathrm{S}}$ ) wet show to day. Sunday 19th. at $17 \frac{1}{2} \mathrm{~m}$. took tat $36^{\circ} 19^{\prime} 25^{\prime \prime}$ at a pond $1 \mathrm{~m}$. above Sharp's cr. at $23 \frac{1}{6}$ Island, at $31 \mathrm{~m}$. lay $1 \mathrm{n}$ rich bottom N. side. Monday 20th. at $9 \frac{1}{2}$ met with the Surveyor ${ }^{06}$ line to far south owing to change of the Variation. net Carvin to-day 06. Who had been calrying the line across country while smith visited the French Lick.

Tuesday 2lst. Ubserved again found as jesterday run the offset. Wednesday 22d. After observing again to-day, and finding the line right Sat off for the Tenasa. ${ }^{\circ}$

07. Smith of course had crossed the Cumberland. Thursday 23d at about $10 \mathrm{~J}^{\prime} \mathrm{Cl}$ sck joyfully surprized with the sight of the Tenasa $140 \mathrm{~m}$. $\frac{1}{4}$ from the Cumberland at our crossing it in Feby. Turnd back and got to the Cunberland that night. These River are but $9 \frac{1}{4}$ miles apart, tho so far from their mouths. 68

68. Another reference to their report of line across heads of G. \& R. rivers.

Friday 24th. got 5 or $6 \mathrm{~m}$. up the river. Dan Frozier \& Jerry Sears went up by land with the Horses.

Saturday 25 th. got to the moth of Sharpes Cr. Set a Sail to-day little wind. 
Sunday 26th. Easter Sundaj. wind agt. us. 27 th wonday, fair wind part of the day, flowy. 28th Tuesday, wind agt. us, pass'd the mouth of Red River.

29 Wednesday wind ast. us. Juth Thursday no wind. 3lst. Friday, got to Harpers Riv 09

69 Col. John Donelson met Henderson's party on this date near this place. Ramsey Anvals 202.

Apl. Ist. Saturday got to Tomhawk Camp (p) Apl. 2 Sunday got to Anos Eaton's

Apl.3. Wonday Rain. Tuesday 4th Rain. Wednesday 5 th sold four horses 3 Lettles some Tents dc. settled sone acets. oth Thursday hunted horses. 7 th Friday. Horses not all found.--Received a letter from the governor to go to the Falls of Ohio on particular business. Col. Henderson brought this letter. 10 wetter in Clarks papers. 392-393-393. Ibid 386. 8th. Saturday, This morning began to recruit a guard to go to the falls. Sunday 9th loth Col. Henderson informed 'twas his opinion Carolina would establish the line we had run, 11 th Tuesday little successin the recruiting way ${ }^{1}$ (71 Ref to having since seen Col. Henderson)

Wednesday 12th. moved to Gaspar Mancoes 1ick. Thursday 13 th. two horses lost, hunted for them all day in rain. Just before we left Eaton's we rec'd of alajor Bledsoe $i$ 454.\%. but on counting it again at a leisure hour found we had made an error in counting one of the parcels, we had counted a 35 for a fifty-five doliar bill-- and that the other parcel was L2. $16 \mathrm{~s}$ more than 200 which it had been countedefor, so that we had recd. no more than 451 3 3. of which I used 11 Dollars to pay Ior the making a hunting Shirt and also pd. Gaspor Mansco his charge of 30 Dollars for Diet at his house while the Horses were hunting. At Gaspar's recd. also L. 45 of Major Bledsoes for other Articles he had sold. recollected afterwards that the -210 was (paid) me by Major Bledsoe for expence which I had paid on the Back Line.

Saturday 15 th Apl. crossed the line lay on the $\mathbb{N}$. fork of the Red. Riv. 
Sunday loth. at $12 \mathrm{~m}$. come to Skeggs Cr. kept down it crossing it sev. times. encamped near the mouth course $\mathrm{N}_{\text {. } 3} 3 \mathrm{~J}$. abt. 27 or $28 \mathrm{~m}$. in the whole.

Wonday 17th: cross'd Skegg's cr. and big barren Riv. this morning then to rocky Spring course N.E. Abt. 13 or $14 \mathrm{~m}$. then N. 10 E. (1eft Trace) $4 \mathrm{~m}$. and encamp' $\mathrm{d}$ on N. Side Green Riv. 72

72. Now on his way north to falls present rouisvilie.

Tuesday 18th. Moved about $10 \mathrm{~m}$. on a course about $\mathbb{N}$. 10 E. encamp' $d$ on a cr. We called Raccoon Cr.

Wednesday 19th. down Raccoon Cr. $2 \frac{1}{2} \mathrm{~m}$. across a hill $1 \mathrm{~m}$. to a large Cr. supposed to be the rolling fork of salt River held on our course and in about $4 \mathrm{~m}$. more came to the sd. cr. again it ran so crooked encamp' $d$ on the E. Side. Course about N. 30 E. $7 \frac{1}{2} \mathrm{~m}$. today in the whole. Thursday 20th. to-day cross'd riv. up a cr. N. 20 E. $1 \mathrm{~m}$. to fork up W. fork W. N. W. $1 \mathrm{~m}$. alone a valley N, $10 \mathrm{E}, 3 \mathrm{~m}$. to riv. W. $1 \mathrm{~m} . \mathrm{N}$. $20 \mathrm{~W} .20 \mathrm{~m}$--reduced to a straight $\mathrm{N} .10 \mathrm{~W} .0 \frac{1}{2} \mathrm{~m}$ on W. Side. Friday 2lst. cross'd cr. twice today at $5 \mathrm{~m}$. it seen'd to bear so much to E. we expected not to cross it again, in all reduced to straight $N_{\text {. }}$ $8 \mathrm{E} .11 \frac{1}{3} \mathrm{~m}$. lay at a pond, barrens a 11 day. continued to where $\perp$ cut my f oot.

Saturday 22d. N. 3 E. $10 \mathrm{~m}$. ( at $/ \mathrm{m}$ a small cr. running to N.W. at $8 \mathrm{~m}$ a dry one with a spring N. W. ) to a Buffaloe road, along the Buffaloe road N. 55 E. $3 \mathrm{~m}$. lay on a cr. along this Buffaloe road we saw liorse tracks waich is the first marks we had seen of any human being having been in these desarts from the day we left rockey spring.

Sunday 23d. Apl. Cut my foot accidentally this morning, trave 1 led $\mathrm{N}$. 18 E. $12 \mathrm{~m} . \mathbb{N}$. $80 \mathrm{E} \cdot \frac{1}{2} \mathrm{~m} . \mathrm{N}, 1 \mathrm{~m}$ t 1 a Lick. N to E $1 \frac{1}{2} \mathrm{~m}$ thro sone knobs to Salt Riv. on which we encamp'd after beginning a raft. It forks about $\frac{1}{3} \mathrm{~m}$. Above us.--Back Water from the Unio se ms to come here. Sonday 24th. Rafted across the River., then N. (U E. 1.t into a Buffaloe 
25

road at foot of the hill which bore to left, we kept it about $\mathbb{N}$. $\mathbb{E}$.

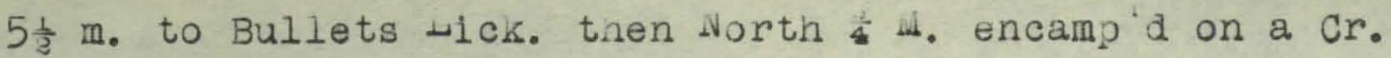

Tuesday 25 th. N. E. abt. $7 \mathrm{~m}$. Into the Trace leading to the Falls along it about North $12 \mathrm{~m}$. to the Falls, where we were told Col. Clarz had left that place 14th Inst. to go to the Iron Banks, 73 One Capt. Hiler of his corps offer'd to carry us down to him as he was just going there and with him we agreed to go. Rain , Thunder \& Lightning this Afternoon-we got very wet, found Smith Hansborough here.

73 Abandoned French Fort $5 \mathrm{~m}$ below Mouth Ohio on wiss. River.

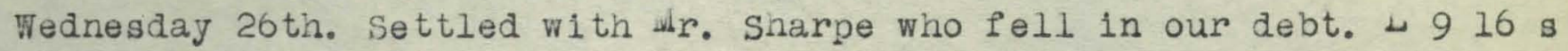
which we paid--he had a bag af terwards. Pd Edwin Garnet his acct. L 25 4 s--Also Jeremiah sears the Same. Also $\mathbb{W}$ I West. the same also Lewis Riland the same. Also let Jno. Jenkins have 35 Dollars and Hugh Hays 6u Dollars. pd for my own use 10 Dollars to Mr. Sharpe for a Knife and 142 Dollars to Smith Hansborough in exchange of Guns. then embarked. Cloudy \& Misty.

If Baper was plenty I would attempt a discription of our uncomfortable situation--with a Xoutippe of a Landlady, something petruchio of Shakespear or Mabal for a Landlord their Dirty chlldren, leaky boat Drunkenness \&c. but I am by no means equal to the task. 74 74. Clark's

Thursday 27 th at day I suppose we were about $15 \mathrm{~m}$. below the mouth of Salt River. To day I recollected the excess of the $200 \mathrm{~L}$ parcel, was owing to Hajor Bledsoe's having paid me 9 Dollars for expense I had pald on the back line. drifted all night, we thought we discover'd an Indian fire on their shore to-night.

Thursday $27 \mathrm{th}$. Nothing nemarkable, drifted chiefly or rowed but little saw several fires on shore to night which we suppose must be caused either by the woods being on fire or by the Indian drifted all night. Friday 28th. rowed d drifted nothing remarizable but searicity of provision, foot painful. 
Saturday 29th. this afternoon passed the mouth of Green River wrote a note to Col. Henderson. Sunday 30th. Strong wind agt. us till afternoon lay still till wind abated, then started. we lay at lellow Banks last night.

Londay 1st. Hay-wind agt. us--hunting parties detained us on an Island opposite to the mouth of Wabash Riv. till near sun down, then started down i row'd all night.

Tuesday 2d iay. Very sick, come by the mouth of Cum: abt $80^{\prime} \mathrm{clock}$ this evening.

Wednesday 3d. This morning at break of day opposite to the old fort dassoe 75 this afternoon at $50^{\prime} \mathrm{clock}$ got to the mouth of the Ohio. tinen down the dississippi about $5 \mathrm{~m}$. to col. Clarkes encampment, who we saw this evening and had some conversation with respecting our business.

75. on Ohio below mouth of Tenn. Thursday 4 th \& Friday 5th. Staid at the Intended Town 76.

76. F.T.Jefferson, Clark and Todd agreed on occupation post begun Apr. 1780 evacinated June 81781 . 1ack of supplies Saturday 6th. Went down to the Iron Bank, encamp'd on the Spawsh shore a little below--rather hazy. Sunday 7 th. Cloudy, rain last night. Londay $8 \mathrm{th}$, clear in the morning but cloudy at noon, run some lines to enable us to know the width of riv.

Tuesday 9th May. cloudy, but being convinced we were north of the line moved to the $\mathrm{S}$. end of the Island--abt $5 \mathrm{~m}$. Wednesday 10th observed. Thursday 1.1th agreed w1th Yesterdays observ. we were $3^{\prime} 19^{\prime \prime}$ in Virginia--from this point of the Island we ran east to the main land where I marked a buckeye elm \& sugar tree tien south 3 m. 265 po. thence West 106 po. to riv. 96 po of which we mark'd. new land is forming here, nothing to mark but cotton trees.--moved up the riv. till abt. $1 \mathrm{~m}$. below wt. clift. - a cr. abt $\frac{1}{6} \mathrm{~m}$, above wt. clift. 
lay in the wet without fire.

Friday 12th. got up to Col. Clarke.

Saturday 13 th embark'd again for hoskoskios ${ }^{27}$.

Kosizosia.

Thursday 18 th arrived at Koskoskios and renained there (which place we made Lat. $37^{\circ} 39^{\prime}$ N. ) till

Londay 5 th June, not well night of 5 th June. left this place to 80 hornewards, arrived at camp Jefferson

Wednesday 7 th June a few minutes after the Indians had murdered 3 men near the town. 2 others were missing supposed to be made prisioners and it appeared that had killed another last honday from his bloody clothes being found in the Indian canoes. people much distressed for want of provisions and in confusion.

Saturday 10th. June. Col. Clark with 2 men sat off to go by land to the falls of Ohio.

Wednesday 14 th June. embarked to go to the falls of Ohio with no more provision than one quart of unsound corn per day for ten days. Tuesday 4th July arrived at the falls.

Thursday 6th. Ssnt for our horses and went as far as Col. Floyds, who lent us $195+15$ of which Jenkins used in Swap of guns and is to be charged with--

Londay 10 th July. got to Horrodsburg ${ }^{78}$ continued on by that place to Willisan's station.

Tuesday 1.1th July got up to Lagan's--overtook Col. Henderson on the rad 12th staid all Day at Lagan's

Thursday 13 th July. left Logan's and got 2 m. S. E. of Chas. English's Friday night 14th: July lay on the most easterly waters of Skegg's cr: before we came to rock castle.

Saturday night 13 th July. lay on Laurel Riv. Waters. Sunday night loth July lay on Richland cr. 
Monday night 17 th July lay cross'd Cumberland lay on Clear Cr. Tuesday 18th July cross'd Cum: mounthin \& lay abt $2 \mathrm{~m}$. east of the Gap. to night the Indians stole 7 of our horses.

Wednesday 19th July followed after our horses and retook them. Thursday 2Jth July got to Trading or.

Friday 2lst. to Crismans Spring--Settled and pd. Hugh Hays $830 \& 270$ Dollars.

Saturday 22d July--parted with Hr. Walker--lay between the stock cr. \& the Rye Cave ${ }^{79}$.

79 on Clinch near Smiths home.

Sunday 23d lay at David Guess Jld place. Monday 24 th. lay at Chas. Hays's

Tuesday 25th. got home. 7 th Auzt. Nonday in the morning early. (Here the Jo irnal breaks off).

Append1x 8

Sumner County, Dec. $81 \$ 15$

Sir--You have asked me all the information I can give you respecting the line run in 1779 and 1780, by Dr. Walker and myself, between the state of Virginia and North Carolina: I have no unwillingness to communi cate the same. We began at or very near the place where Messrs. Fry and Jefferson left off theirs in the year 1748 or 1749 on steep rock creek a branch of dolston river; I say at or very near the place because close to the creek, whatever marks they made had become obliterated by the encamping of hunters or other persons at the place--I did myself, follow their old line from the top of the next mountain east of the creek, distant I think, 8 or 10 miles, to within a mile and a half of the creek. The comisioners from North Carolina were Col. Richard Henderson, Col. John Williams and Major William Baily Smith, We were all agreed that the place of beginning was right and that we set out on the proper course and as far as 1 know continued of that opinion 
until we arrived in Carter's Valiey, on the west side of the North Fork of Holston. Then the North Carolina gentlemen expressed a belief that we were in an error. And shortly after (from what cause I cannot be positive) left us and run another line as I suppose, some what more than two miles north of ours, and which they first assented to.

As much the greater part of the expense of marking this line had, accrued, and as it appeared to us very material that the southern boundary of the Virginia military donation land should be ascertained, because the country on the Cumberland river about the place called the French Lick, was rapidly filling up with settlers, we concluded to continue the line as we thought right. When we had extended it to the clear fork of Cumberland river, the winter sat in so cold, \& the country we had to pass through was mountaineous and barcen, that we believed subsistance could not be procured for ourselves andpack horses. We therefore left the tract of country and traveled down the cumberland River to a place, a little below the mouth of Fishing creek, where we built canoes in the very had weather to transport our baggage; af ter the winter moderated a little we descended the river to the proper latitude, a little above the mouth of obed's river. From this place, while Dr. Walker went down the river with the baggage; accompanied by our surveyor, 1 continued on the line, and after giving the surveyor proper directions at the trace leading from sentucky to the French Lick, I parted with him to meet Dr. Walker as we had appointed at the said. lick. Then we proceeded down the river and met the surveyor on its banks about two miles south of the true line, owing as we believed to a change in the varlation of the needle, caused by large quantities of iron ore in the neighborhood. We went into the proper latitude, and continued west to the Tennesse river, then returned back to Cumberland where we had left it, and continued the line east, intending to pursue 
that course until it should touch the line run by our surveyor at the place $\perp$ parted with him. But finding the country one vast extent of open barren, not furnishing trees to mark, we relinquished the line and corninenced our journey home.

Un our arrival at French Hick we recelved a letter from the Governor Galvez was then conquering the Natchez country and the adjacent parts Prom the British, to 80 to the Falls of Ohio to Col. Clari, and apply to him for a guard; descend the unio and lississippl rivers to the proper latitude and there maze marks and give all the publicity we could to the claims of Virginia that far south. This duty we performed and then returned home. Un our way, we fell in with col. Henderson, who told us more than once that North Carolina would sanction what we had done, - Whether he made report to that state, and to what purport, we have not been informed. Jur report, Dr. Walker handed to the legislature of Virginia, which $\perp$ understand was properly received and deemed quite satisfacory. This was in the height of the revolutionary war Great Britain, when business of this kind was deemed of far less consequence than, by every exertion to repel the enemy from the country. This enemy came aftemards to Richmond and as $\perp$ have understood destroyed many of the public papers and records.

1 cannot but observe, that through Holston part of the country, it has been supposed by many, we had run the line to far to the southward, and from a magnanimous spirit of accomodation, Virginia relinquish ed her claim to about a mile of Territory. Through the cumberland couritry we have been suspected of running the line to far to the northward. Why such suspicions should arise, $\perp$ know not. un only desire I well know was to run the line in the proper latitude. I am sir,

With great respect, $c$.

Daniel Smith

A copy of General Daniel Smith's letter appeared in the Nashville 
Gazette, Harch 11820.

Tenn. the Vol. State.

\section{Appendix 9}

1790 Report

Uf the Comnittee of the Legislature of North Carolina, on

Walker's Line at their Session at Fayetteville, Which Began on the $2 d$ of November and Ended on $22 d$ of December, 1789.

Mr. Ierson, from the comnittee to whom was referred the letter from his Exce llency, the Governor of Virginia, on the subject of establishing the boundaries between this State and Virginia, reported that $1 \mathrm{t}$ is proposed on the part of Virginia that the line be established as the boundary between us. Should this proposed not be acceptable to this state, they will appoint commissioners to meet any persons who may be appointed on the part of North Carolina empowered to confer on the propriety of establishing Walker's or Henderson's line, and to report to the Legislatures of their respective states their proceedings. Un examining the manner in which those lines were run by the comissioners in the year 1780, they find that the commissioners began and extended the line together about forty miles, when some difference to place, and the commisioners on the part of this state run a parallel line two miles north of the other line, for about half the distance, and extended the line no farther. Wr. Walker and the other comissioners from Virginia extended the line to the Tennessee River, marked its termination on the Missippi by observations, leaving the line from the Tennessee to that place unsurveyed. As the difference between said line would only be two miles. running most of the distance through a mountainous, barren country, and as they have great reason to believe, from the information of General Smith, that the comnonly called Walker's Iine is the true line, your cominitee are of the opinion that the object is not worth the expense of sending commissioners to confer on the propriety of establishing Henderson's line in preference to that of any 
other, and do recominend that a law be passed confirming and establishing the line usually called Walker's line as the boundary between this State and the State of Virginia, with a reservation in favor of the oldest grants irom either state in deciding the rights of individual claimants in the tract of country between the two lines commonly called Henderson's and Walker's lines. Haywood 497.

Report

State of North Carolina

In the House of Commons, December 111790

The committee to whom the letter from the Governor of Virginia on the boundary line between this and the state of Virginia was referred report that it is the opinion of your committee that the boundary line between the states of North Carolina and Virginia be confirmed agreeable to report of a committee, concurred with by both liouses last session of Assembly, and that a law be passed confirming the line commonly called Walker's line as the boundary between the States of North Carolina and Virginia, reserving the right of the oldest patents, grants, or entries nade in either of the States.
All of which is submitted.
Thomas Person, Chairman

In House of Commons, 11 December 1790. Read and concurred with,
S. Cabarrus S.H. C.

In Senate, 11th December, 1790

Read and concurred with, William Lenoir, S.S.

Haywood 498

Appendix 10

1792

Richmond, Jctober 24 1/92

Sir:

For many sessions past has the General Assembly of this Commonwealth turned their attention toward the establishnent of the boundary line between North Carolina and this State. 
In the course of last year the Executive received from the Governor of North Carolina the enclosed proceedings of the Legistature of that State, and communicated the same to the General Assembly.

In consequence whereof an act was passed, entitled, "An act concernIng the southern boundary of this state," and duly promulgated, a copy of which I herewith forward.

This Commonwealth was governed, on this occasion, solely by a proper solicitule to prevent the possibility of subsequent difficulties which might arise fron the want of an acknowledged boundary between the two States.

The acquisition in territory or people was too small an object to engage the attention of a cummunity whose conduct, as a member of the American confederacy, has been signally narked by her gifts and her cessions.

We could never conceive, on the present occasion opposition from any quarter to the complete execution of a law deemed essential to the peace and quiet of two states.

But a copy of Governor Blount's letter, herewith transmitted shows that he considered himself bound, by his duty as an officer of the United States, to disregard the law establishing Walker's line as the southern boundary of this Commonwealth.

Thus, sir, not only is the object of the General Assembly defeated, but the cltize ns living between the real line and the pretended line are subjected to unmerited sufferings, of which they justly complain.

You will find among the papers a copy of a letter from Mr. Martin, whose information on this subject I believe to be worthy of full credit, and which goes to do away the ground of the opini n entertained by Governor Blount.

I would enter more particularly into the explanation of this business, but really i concelve it by no means necessary, as the transaction 
speaiss for itself, and the accompaning papers declare the sense of Virginia and North Carolina, and manifest the oposition made to the law of this Commonwealth, as well as the reasons for such oposition. Let me entreat you to lay the same before the President of the United States, and to favor me with the Presidents decision as soon as may be convenient.

I have the honor to be sir, with sentiments of the highest respect, your obedient, humble servant,

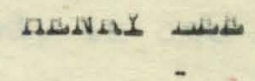

The Secretary of State, Philadelphia

American State Papers, Vol 37 pp 54

\section{Appendix 11}

An act concerning the Southern Boundary of this State passed December 71791

Whereas official information hath been received by the General Assembly the Legislature of the State of North Carolina have resolved to establish the line commonly called Walker's line as the boundary between North Crolina and this Commonwealth, and it is judzed expedent to confirm and establish the Sald line on the part of this State.

Be it therefore enacted by the General Assembiy, That the line commonly called and known called and known by the name of Walker's line shall be, and the same is hereby declared to be, the boundary Ine of this state.

Sec. 2. And be it furtiner enaited, That in all courts of law and equity within this commonwealth, the claim for lands lying between the line commonly called Walker's line and the linecommonly called Henderson's line, shall be decided in favor of the oldest title, whether derived from this Conmonwealth or the State of North Carolina. American State Papers, vol 37 pp 56 
Sir:

\section{Appendix 12}

Agreeably to your request I have made every inquiry respecting the lines called Walizer's and Henderson's, which are the subject of dispute between this State and North Carolina, but my knowledge of that country might not be sufficient to lead to accurate information; but I can find no person that can render me any assistance. As far as my knowledge serves, I can inform you that from steep rock to Cumberland mountain, where Henderson stopped, is one hundred miles. Walker proceeded as far as the Hississipul. Tre widin between the two lines, as far as Henderson proceeded, is between two and three miles. I think there are about one hundred families living between the lines, the greater part of whom are desirous of continuing in Virginia. About onefourth are content to remain in statu quo, as they are exempt from paying tax.

The lower station in Powell's Valley, is between the two lines; they consider themselves under the protection of Virginia. The Virginia law is adhered to there; and all titles to lands are from the Government of Virginia.

You will find that when the cesgion was made from North Carolina to Congress, reference was had to General Smith, without nentioning who General Smith was. At the time the line was run, he was esteened the best mathmetician, and therefore appointed to assist in the extension of the line. At the passage of the bill in North Carolina for the cession he was a member of Assembly, and called on for information. I was also a member at that time. The decision respecting the lines, as I understood the matter being one of the comnittee, took place at the passage, or rising of the Assembly.

The cession to Congress was on certain stipulations, which could not take place before the pleasure of Congress was known, which was 
some months after.

I have business in Fowell's Valley, which will call me there in February next,if necessary, after that time I can give you a full account of the families, their names, militia, \&c.

I have the honor to be, your excellency's obedient servant

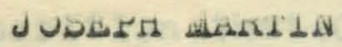

His Excellency Henry Lee, Esquire, Governor of Virginia. American State Papers. Vol $37 \mathrm{pp} 54$.

\section{Appendix 13}

Dear Sir:

I have received a few lines from you, wherein you request a copy of Governor 's orders to me, respecting the jurisdiction and claims we have to the lands and people between the lines.

Some time ago I write you, in full, ny sentiments on the subject, agreeable to the cession act; at which time I had no special order respecting the people between the 11 nes, and I wrote to the Governor to know how I should act. He sent me orders in these words: "That I was to pay no respect to the claims or to the jurisdiction that virginia had to the land between the lines, but to punish offenders against our laws, so residing as elsewhere".

From jour friend

To Colonel Arthur Campbell

American State Papers

Vol. 37 pp 54

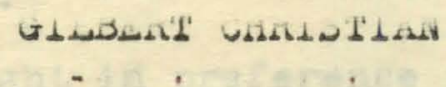

\section{Appendix 14}

On June 181792 Gilbert Christian, Justice of the Peace for Sullivan County issued warrants for the arrest of the following can Baily, 
Charles Wolf, James Anderson, and James Campbell all members of Captain Bosherses Company. They had been absent from muster in Sullivan county on June 15 1792, and these warrants were issued on the proceedings of Courts Nartial of June 161792.

September 61792 Charles Wolf came before Robert Preston J.P6 of Washington County Va. and made a deposition that Constable Edward Devise of Sullivan county N. C. served this warrant on him Aug. 4 1792 and that he paid four shillings covering costs and fine for which he received a fine.

On same date James Campbell made deposition that Devise had served a warrant on him $18 \mathrm{July}$ last and that he had paid fine and costa amounting to twenty-four shillings, for which he received a receipt which he handed over to Colonel Artinur Campbell, the county Hieut. for Washington County, Va.

Appendix 15

A.S.P. Vol 37 pp 55

Extract from Governor Blount's letter to the Governor of Virsinia. September 21792

I have also to acknowledge the recelpt of your letter on the subject of the boundary line between the Commonwealth of Virginia and this Territory, enclosing an act concerning the same, and your proclamation for the promulgation thereof.

Whether Aenderson's line is right in preference to Walker's, or the contrary, or whether either is right, I concelve is jet to be determined; but North Carolina having exercised jurisdiction to Henderson's line from the time it was run, without any objection on the part of the State of Virginia, to the time the state of North Carolina passed the act of cession, and after, to the dissolution of the Government of North Carolina, as to the part ceded, and the 
organization of the territorial Government thereon (a term of more than ten years, ) I conceived my duty as Governor also to extend the Jurisdiction of the territorial Government to Henderson's 1ine: and still believing it to be my duty the law of virginia and your proclamation notwithstanding. I shall continue to exercise jurisaiction to that line until I shall receive instructions to the contrary from the federal Government.

It is observable that the act of Virginia, declaring Walker's line to be the southern boundaey, is founded upon a resolution of the Legislature of North Carolina, establishing that line as the boundary between Virginia and that state and not upon the principle that that line is precisely where it ought to be; and no doubt that resolution and your act effectually fix that as the line between North Carolina and Virginia; but it is equally clear that, on no resolution or act of North Carolina, passed after Congress accepted the cession of that S tate, which is unquestionably the case with the resolution on which your act is founded, can be so construed as to bind the united states to consider that line as the boundary between Virginia and this Territory.

Appendix 16

$1792--N_{\text {OV }} .9$

\section{2nd Congress 2nd session.}

Boundary between Virginia and the Territory south of the Ohio. Communicated to Congress November 91792.

Gentlemen of the Senate and of the House of Representatives;

I now lay before you a letter from the secretary of state, covering the copy of one from the Governor of Virginia, with the several papers therein referred to, on the subject of the boundary between that state and the territory of the United States south of the Uhio. It will remai $n$ with the Legislature to take such measures as it shall think best for settling the said boundary with that state, and, at the same time, if 
It thiniss proper, for extending the settlement to the state of Sentucky, between which and the same territory the boundary is as yet unde termined.

Geo. Washington

American State Papers, vol 37 pp 54

\section{Append1x 17}

1794 Dec 8.

\section{3 rd Congress and Session}

Boundary between Virginia and the Territory South of the River Unio. Cummunicated to the House of Representatives, December 81794.

Mr. Preston, from the cominittee to whom was referred the petition of sundry cltizeng of the United States residing between the lines comonly called Walker's and Henderson's lines, praying the former may be established as the dividing line between the state of Virginia and the territory south of the river, Ohio reported the following resolution;

Resolved, That a law should pass establishing Walker's line as the southern boundary betwe on the State of Virginia and the territory of the United States south of the river Ohio, reserving to the said inhabitants their claims to lands lying between said lines, acoroding to the laws of the state under which they claim. American State Papers vol 37 pp 113

\section{Appendix 18}

1801

An Act concerning the boundary line of this state and the state of Tenneśsee. Approved December 141801.

Whereas doubts have arisen with respect to the position of the boundary line, or some part there of between this state and the State of Tennessee, therefore

Be it enacted by the General Assembly, That the Governor of this State be authorised and requested, as soon as he is informed that 
comnissioners are appointed on the part of the state of Tennessee, to appoint two commissioners to meot such commissioners, and with them to settle and remove all doubts upon the subject aforesaid, by running and marking the said line, or as nuch thereof as may not extend within the lands reserved by congress to any Indian tribe, agreeable to the chartered linits of the S tate of Virginia and North Carolina; and the commissioners so appointed shall have power to employ a surveyor, and as many hands as may be necessary to carry the same into effect, at the joint expense of both states. The commissioners so apjointed on behalf of this state shall receive for their services and expenses three dollars per day for every day they may be actually employed in going to, continuing, and returning from said; and shall make report to the Governor of their proceedings as soon as the same is completed; and also certify how many hands were employed, and for what purpose, and what is due to said hands from this State; which report and certificate the Governor shall lay before the next Assembly. And if the proceedings of the said Commissioners shall be approved by this state and the state of Tennessee, the line so run and marsed shall be the line forever between the said states, unless altered by mutual consent. If any lanls claimed under titles derived from the state of Tennessee shall be found on running the said line as before mentioned, to be within the limits of this commonwealth, all such claims shall, as soon as a reciprocal law shall be passed by the Legislature of the state of Tennessee, on behalf of persons claiming lands lying in the said $s$ tate, unler titles derived from this state be as valid as if they were derived from this cominonwealth. And the Auditor, on the order of the Governor, shall issue a warrent to the said commissioners for any sum not exceeding one hundred and $\mathrm{fifty}$ doliars, to enable them to provide for the execution of the businesg: assigned them by this act, and the Treasurer the same accordingly, 
out of any money in the treasury. The Governor of this State shall transmit a copy of this act to the Governor of the state of Tennessee as soon as possible, who is requested to lay the sane before the next Legislature which shall be held for said state. American State Papers vol 38 page 492.

1802

\section{Appendix 19}

An Act to repeal an act entitled "An Act concerning the boundary line between this State and the State of Tennessee, Ap. Dec. 221802.

Where as it appears to this present General Assembly that the act passed at the last session entitled, "An Act concerning the boundary line between this $S$ tate and the state of Tennessee is defective, in as much as it provided that the boundary line between the said states shall be run agreeably to the chartered limits of the states of Virginia and North Carolina, and it does not appear to us that any charter ever was granted describin 8 the limits of the last mentioned States, respectively: therefore,

Sec. I Be it enacted by the General Assembly, That the said reeited act shall be and the sane is hereby, repealed.

Sec. 2 An be 1 t further enacted, That the Executive of this state shali, as soon as, possible, send a copy of this act to the Governor of the State of Tennessee. American States Papers, Vol 38 pp. 492

Appendix 20

1803

Acts of Tennessee

An sct to ascertain and establish the true boundary line between this state and the state of sentucky. November 3. Whereas doubts exist relative to the position of the boundary line between this state and 
and the state of Eentucky--Therefore it is expedient that the line between the states aforesaid should be ascertained and established:

Section 1. Be it enacted by the General Asgembly of the state of Tennessee, That the governor of this state be authorized and required, as soon as he is inforned that a commissioner or commissioners are appointed on the part of the state of Kentucky, to appoint one commissioner, who shall also be a matmmetician, to meet such comnissioner or commisioners, and with him or them to settle and remove all doubts upon the subject aforesald, by running and marking the line between the states aforesaid, agreeable the chartered linits of the state of Virginia and North Carolina; and the commissioner so appointed shall have power to employ a surveyor and two markers to extend and indentify the aforesald line.

Sec. 2. Be it enacted, That the comnissioner, so appointed shall recelve the sum of four dollars, per. day, for every day necessarily engaged in running said line, and the lize sum for every twenty-five miles travelins to the place where the line is to cominence and returning from the place where the line terminates. And the survejor shall receive the sum of two dollars and fifty cents for each and every day he shall attend in running said line, and the like sum for every twentyfivefmiles in traveling to and from the same. And each narker emplojed as aforesaid, shall receive the sum of one dollar and twenty-five cents for each and every days attendence and the like sum for every twentyfive miles traveling to and from the line aforesaid.-And it shall be the duty of the commissioner aforesaid, to nake report of the proceeding to the governor as goun as gald line is comjleted, and cerblly to the governor the number of days they shall have been employed in running said line, and the miles they shall have travelled in going to and returning from the same, and also the attendence and traveling of the surveyor so employed as aforesaid, and likewise the attendence and 
and travelling of the makers emplojed as aforesaid, which certificate shall be sworn to and subscribed before some judge or justice of the peace and certify by him, which report and certificate the governor shall lay before the next general assembly; and if the proceedings aforesaid shall be approved by this state, and also by the state of sentucky, the line so run and marked shall be the line forever between the said states, unless altered by mutual consent.

Sec.3. Be it enacted, That if any lands clained under title derived from the state of sentucky shall be found, on running the said. line, to lie within the limits of this state, all such claims shall, so soon as a similar and reciprocal law shall be passed by the legislature of the state of Aentucky on behalf of persons claining lands lying within the said state, under titles derived from this state or the state of No. Carolina since the jear one thousand seven hundred and seventy-geven, be as valid as if it derived from this or the state of North Carolina since the year one thousand seven hundred and seventy-seven.

sec. 4. Be it enacted, That the sum of three hundred dollars is hereby appropiated for the purpose of carrying into effect the extension of the aforesald line, which shall be paid into the hands of the commissioner appointed as aforesaid, upon a warrant drawn by the governor on the treasury.

Sec.5. Be it enacted, That the governor as soon as ray be shall transmit a copy of this act to the executive of the state of Rentucky, with a request that he lay the same before the general assembly of state at their next netting.

James Stuart, Speaker Hous representatives James White, Speaker Senate. 
1812

Appendix 21

An Act to provide for the ascertainment of the boundary line between this State and the State of Tennessee. Ap.Feb. 41812.

Whereas it is desirable to have the boundary line between this state and the state of Te nnessee run and marked according to its true position and whereas the General Assembly of the state of Tennessee have passed a resolution at their last session authorizing the Executive thereof to appoint two commissioners to cause to be run and marized the boundary line between this state and tae state of Tennessee; wherefore,

Sec. I Be it enacted by the General Assembly of the Commonwealth of Lentucky, That the Governor of this state be, and he is hereby, authorized to appoint two fit jersons as commissioners, who shall be, and they are hereby, authorized to meet the commissioners to be appointed on the part of the state of Tennessee under the resolution aforesaid, and then proceed to run and mark said line according to its true position, as it is established by the charter of iling charles II, and recognised by the twenty-fifth section of the declaration of rights in the constitutuon of the State ff North Carolina and also recognised by the thirty-second section of the declaration of rights in the constitution of Tennessee, beginning on the top of Cumberland mountain, at thirty-six desrees and thirty minutes north latitude, when accurately taken, and from thence to run west a right line in thirty-six degrees and thirty minutes north latitude, so far as not to run into the lands claimed by the Indians.

Sec.2. Be it further enacted, That the said commissioners empowered to employ a surveyor at three dollars and fifty cents per day, and chain carriers and inarkers at one dollar per day each, and cause the said line to be run and marked between this state and the state of Tennessee, agreeably to the provisions of this act.

Sec. 3 Be it further enacted, That the comnissioners so bo be appointed on behalf of this state are authorized to confer with the com- 
missioners on behalf of the State of Tennessee as to the most advisable plan for quieting the titles to land which nay be claimed by the citizens of either state between the boundary line and the line commonly called "Walker's line".

Sec. 4 Be it further enacted, That if the commissioners on the part of the state of Tennessee shall fail or refuse to act and proceod with the commissioners to be appointed on the part of this state, or if the Executive of said state of Tennessee should not appoint such commissioners, nevertheless the commissioners so to be appointed on the part of this state may proceed (uniess forbidlen by the Executive of the State of Tennessee, ) upon proper observations of the true point and direction of thirty-six degrees and thirty minutes north latitude, to cause the sald boundary line to be run and marked so far as not to run into lands at present claimed by the Indians.

Sec. 5 And be it further enacted, That said cominisioners shall, for the time they shall be necessarily employed in said service, each recelve the sum of five and a half dollars per day, and that upon the Governor's certificate if their appointments as commissioners, and of their being ready to proceed to the discharge of these duties herein prescribed, they shall be entitled to draw a sum from the treasury of this state, (for which the auditor is hereby required to issue his warrant on the treasurer, ) not exceding six hundred doliars, for the payment in part for a surveyor, chain-carriers, markers, and furnishing the requslte provisions; which latter shall be furnished at the expense of the state.

Sec. 6 And be it $f$ urther enacted, That it shall be the duty of the commissioners to report their proceedings together with an account of the necessary expenses of said services, to the next session of the Legislature. 


\section{Appendix 22}

1812

Acts Tennessee, Chap. 58.

An Act to confirm and establish Walier's line as the boundary this State and the state of rentucisy. Uctober 21.

Sec. 1 Be it enacted by the General Assembly of the state of Tennessee, That the line commonly called and known by the name of Walker's line shall be and the same is hereby declared to be the boundary line of this state so far as the same has been run and marked under the direction of Walker, and where it has not been run and marked the governor of this state is hereby authorized to appoint two persor. commissioners on the part of this state, to act with commissioners to be apointed by the authority of the state of sentucky, finaliy to adjust and establish such part on said line as has not been run and marked, paying due regard in running thereof to those established, and notorious points in said lines at which the latitude has been taken and places marked by said Walker.

Sec. 2. Be it enacted, That said conmissioners shall appoint one or more surveyors and markers who shall plainly mark the line at all places where the same has not been done. Each commissioner shall be allowed the sum of four dollars per day, and each surveyor three dollars, and each marker the sum of one dollar for each day he shall be engaged in said service to be paid out of any monies in the treasury not otherwise appropriated, to be drawn on the warrant of the governor who is hereby authorized to draw warrants for the sane. Said commissioners shall make report of their proceedings to the executive of this state so soon as they shall have accomplished the same.

Sec. 3. Be it enacted, That the governor of this state shall be requested to transmitt a copy of this act to the executive of the state of Sentucky.

Speaker of the House of Representatives. Thomas Henderson 
$1812-13$

An Act concerning the boundary between this state and the state of Tennessee. Approved, February 31813.

Whereas it appears from the communications made by the governor to this legislature, at the commencement of this session, that the legislature of the state of Tennessee, by an act of their last session, have indicated a disposition to depart from the proposition formerly nade by their government to this, of proce eding by the agency of comnissioners, mutually appointed on the part of each and acting in concert together, to ascertain by correct and scientific observation the true line of separation between the respective states, agreeably to their chartered linits. And whereas, it is deemed by this legislature, that the true interests, and sound policy of this state, as well as that of Tennessee require an explicit declaration of the views and ulterior determination of each other on this point, so important to the cultivation of harmony, and a proper understanding between the governments, as well as citizens of two contiguous and friendly states. Wherefore,

Sec. I Be it enacted by the General Assembly, That the governor of this commonwealth be requested to communicate to the executive and legislature of said state, the final determination of the government of this commonwealth, in relation to the ascertainment of the said boundary line, to be in conformity with that evinced by the government of Tennessee, in their proposition to ascertain the true boundary line between the sald states agreeably to their chartered limits, as first alluded to in the preamble of this act; and to sollcit in the most respectiul terms from the said Jovernment, a recognition of this principle, and a correspondent determination on their part, with the adoption of the necessary measures for carrying the same into complete operation, and further expressing to the said government, in case of their final rejection of this overture, the disagree able necessity imposed upon the government of Kentucky, of having the long contested question 
finally settled by a resort to the means pointed out by the constitution of tie United States, for the decision of such controversies. Acts of $1812-13$ pp 93

Chapter LXXIV.

\section{Appendix 24}

1815.

Acts Tennessee, Chap. 191.

An Act to establish \& confirm the boundary line between the state of Lentuciky and this state. November 17.

Whereas some difficulty nas existed between the state of Kentucky and this state respecting the boundary between them, and whereas it is essential to the harmony \& interest of both states, that the line commonly called Walker's line here tofore considered, and acted on, as the boundary between them, should be established as the boundary between the two states, therefore

Sec. 1. Be it enacted by the General Assembly of the state of Tennessee, That the line commonly called Walker's line be, and the same is hereby established and confirmed as the true boundary between the state of Kentucky and this state.

Sec. 2. Be it enacted, That all entries \& grants which may have been made or issued for land on the south side of sald line, at any time before the first day of November one thousand eight hundred and fifteen, either under the authority of the state of nentuciry or of this state be, and the same are hereby establishod \& confirined to the claimants under such entries \& grants, and where entries nay have been made under the authroity of the state of Lentucky, grants may be issued thereon by said state in the same manner as if the land lay within said state of Kentucky, provided such entries and grants would have been valid by the laws of the state under which they were made or obtained. sec. 3. Be it enacted, That the governor shall, and he is hereby 
empowered to appoint some suitable person a commissioner to attend the general assembly of the said state of nentucky, at their next session, and present to them a certified copy of tilis act, and request them to pass an act confirming the said line, and confirming the titles obtained under the authority of this state or sentucky, for land on the North side of said line, according to the priority of their dates, as provided for by this act, and to appoint a commissione on the part of said state to act with the commissioner on the part of this state, in running and marking said line. And if the legislature of said state shall, pass such an act, tien the commissioner on the part of this state shall have power to act with the comissioner on the part of Kentucky, in running and marking said line, or such part there of as they may deem necessary to run and mark, and sha 11 have power to appolnt one surveyor and as many chain carriers and markers as may be necessary.

Sec 4. Be it enacted, That the comnlssioner on the part of this state shall be allowed five dollars per day, the surveyor four dollars per day, and each chain carrier and maker one dollar per day for each day they may respectively be engaged in the business prescribed by this act, to be paid by either of the treasurers of this state, the commissioner on the certificate of the governor of his appointment, and the number of days he may have been engased, and the survejor, chain carriers and markers, on the certiflcate of the connissioner of their employment and the number of days they nay have been respectively enmaged in said business.

Sec. 5. Be it enacted, That if the legislature of Lentuciry shall refuse to pass such an act as above stated, this act shall cease to be in force from and after the time of such refusal, except so much thereof as provides for the payment of sald commissioner. 


\section{Edward Ward}

Speaker of the senate

\section{Appendix 25}

1815-10

An Act to settle the Boundary Line between this State and the State of Tennessee. Ap oroved, February 101810.

Whereas, a dispute exists as to the true position of the boundary line, between this state and the state of Tennessee, which has produced many attenpts at accomodation hitherto unsuccessful; and the state of Tennessee, by an act of its legislature, passed on the seventeenth day of November, in the year one thousand eight hundred and fifteen, has appointed a commissioner to wait on the constituted authorities of this state, and adopt the principles for adjusting the said boundary line; and although this state cannot meet every proposition contained in the said recited act, and pass one on the part of this state in all respects similar: because, first, the establishment of Walker's line (as it is usually called) would not determine the whole extent of boundary between the two states; and secondly, because this legislature is forbidden by our own constitution, to form any compact with a sister state, or do anything within the perview legislative authority, which might take from individuals a right of property in lands near the contemplated line, without previously paying the claimants a compensation therefor. Yet, the legislature of this state, being willing to zeep open the door of accomodation and adjustment, and feeling desirous that mutual harmony between the two states should not be molested by a territorial controversy, do propose the following terms;

Sec. 1. Be it enacted by the General Assembly of the Comnonwealth of Kentucky, That the line usually called Walker's line, so far as it was origionally run and marked, to wit; From a point near the mouth of Obed's river, to the Tennessee River, be the true jurisdictional 
Iine between this state and the state of Tennessee. And as to the residue of the line between the two states, the following shall be adopted as the true position thereof: At the eastern extremity of Walker's line, near the mouth of Obed's river aforesaid, a line shall be at right angles elther north or south, as the case may require, till it reaches the true chartered limits of the two states, in the latitude of thirty-six degrees and thirty minutes north, and from that point the line shall be extended to the east, still keeping the sane latitude, till reaches the eastern boundary of this state. And at the west exteemity of Walker's line, to wit: At the Tennessee river, a line shall be extended up or down said river, (as the case may require) till it reaches the true chartered latitude of thirty-six degrees and thirty minutes north; and from that point, the line shall be extended due west, still keeping the same latitude, till it reaches the river Missigsippl. And the line so pointed out by this act, shall be, and remain the true jurisdictional line, between this state and the state of Tennessee; provided the following articles, conditions and stipulations hereby adopted on behalf of this state, are acceded to on the part of the state of Tennessee, to wit;

FIRST. The line so pointed out shall be marked or remarked and well cleared, at the joint expence of each state by two commissioners, attended with proper survejors, chain-men, makers and laborers. And one of sald comissioners shall be appointed by each state. And in running that part of the line (called Walker's line) the commissioners shall be governed by the old nariers, if they can be found, or the most notorious places of the line, as now acknowledged, still making the line as straight as can be practicable, if the old line shall be found to be crooked.

SECUND. The true chartered limits between the two states, shall be run on that part now supplied by Walker's line and marked in numerous 
places, so that hereafter, it may be found with ease and convenience, and may furnish evidence of the situation of claims when they shall be adjusted as hereafter directed.

1Hent. If the true chartered limits in that part of the line supplied by Walker's line, shall turn out to be north of Walker's line and encroach on what is now under the jurisdiction of Kentucky, and any fair connected titles to land derived under the laws of the states of North Carolina or Tennessee, conpleted by patent from the proper authority, shall appear between $W_{a} l k e r ' s$ line and the true chartered line, and shall interfere with any title or cover any occupant, holding title under the laws of this state or the state of Virginia, the claimants, at their option, may relinquish such claim, and be entitled to compensation for the value thereor, from the state of sentucky, ascertained in a manner pointed out by this act; or such claimants nay take any remedy to recover the land, which may be most proper for their case. And if, on the contrary, the true ch rtered limits shall be gouth of Walker's line, and include a portion of the land now under the jurisdiction of the state of Tennessee, and any fair connected titles to land derlved under the laws of the states of Virginia or Nentucky, completed by patent from the proper authority shall appear between Walker's line and the true chartered line, and shall interiere with any title, or cover any occupant holdins title under the laws of the states of North Carolina or Tennessee, the claimants at their option, nay relinquish such claim, and be entitled to compensation for the value thereof, from the state of Tennessee, ascertained in a manner pointed out by a stipulation between the two states; or such claimants may take any remedy to recuver the land which may be most proper for their case.

Fourth. If any claimant holding title under one state, shall not elect to take compensation for the land, accroding to the next preceding 
article, and shall by any suit in law or equity, recover the land from any occupant holding title under tine laws of the otier state, he shall be compelled, in a mode pointed out by the laws governing such court, where the recovery may be had, to compensate the occupant for his improvements on the land, according to tueir intrinsic viaue, without any deduction for rents or waste: and for such compensation the occupant shall have a lien on the land so recovered; and shall not be disturbed in the possession thereof, till the compensation legally ascertained, shall be paid to such occupant.

FIFTH. If any claim for land shall fall between Walker's line and the true charteced limits and shall come under the jurisdiction by arrangement of the state from which title did not originate, and shall not be patented when the line is thus settled, and shall interpere with a title derived Irom the state to whom the jurisdiction shall be assigned by this compact, no pacent shall ever 1 ssue therefor; and all patents issued contrary to this article shall be vold.

sLXIB. If in the territory ceded by this compact, there shall exist any claim between Walker's line and the true chartered limits, which claim shall be regularly derived, under the laws of either state, or the parent states, and shall not interfere with any other claimant, but shall be on land vacant as to other claims; the same sha 11 be, and is hereby ratified, and if not completed by patent, provision shall be made by the state into whose jurisdiction it may fall, to complete the titie by the emanation of the grant.

SEVENTH. And whereas it is believed that many clains granted for actual settlement under the Laws adopted by the state of sentucky since its separation from Virginia, were granted contrary to the true intent and meaning of said laws, without any actual bona fide settlement; and some of them are laid out south of what is actually Walker's line; and It is also believed that many removed certificates under the laws of 
the Commonwealth of rentucky, origionally granted for actual settlement, have been removed and located for speculative purposes, south of Walcer's line: Now it is hereby declared, that such claims, where they interfere with any claims derived under the laws of North Carolina and Tennessee, south of Walker's line, are not aided by the provisions of this act; and that the owners of such clains shall not be entitled to any compensation under this compact, provided the fall within the ceded territory; nor shall the state of Tennessee be bound to allow patents to eminate for such claims, unless they are entered on land entirely vacant.

Eighth. If any claimant between walker's line and the true chartered limits, shall choose to relinquish his claim, according to the first article of this compact, he may produce authenticated copies of his titie papers to court of general jurisdiction of matters of law and equity in the state of Kentucky, which may hold its sessions nearest the lands so to be relinquished; and also to some court of the state of Tennessee, which may posess general jurisdiction of matters of law and equity, and which may hold its sessions nearest the lands so to be relinquished; and said courts shall appoint some discreet person to act as commissioner to value said lands, so to be relinquished, if the claim shall come within this act: and said commisioners shall proceed to appoint and associate with them, one other commissioner; and the three being duly sworn before some judge or justice of the peace will and truly to value the land so relinquished, accurding to the best of their skill and judgment, without partiality or favor touither partj, and without regard to any improvements which may have been made thereon, shall proceed to value said lands, and certify the same un er their hands and seals, and are producing said valuation to the court appointing the commissioner, in the state where the land 11es; and also producing a certified copy of the relinquishment of sald land, according to 
the laws of that state where the land may then be; the court shall order the value thereof, so ascertained by commissioners, to be certified, and the same shall be paid out of the public treasury of the treasury of the state, in which the land may be situated.

Sec.2. Be it furtier enacted, That if the state of Tennessee shall pass a law at or before the next stated session of their legislature, similar in all respects to this act, the governor of this state shall proced to appoint a fit person as commissioner, to run and ascertain the position of the lines directed to be run by this act; who shall receive for his services five doliars per day, during the time he shall necessarily employed in running the lines aforesaid, and five dollars per day, for every twenty-five miles he may necessarily travel in going to and returning from the lines aforesaid. The surveyor or surveyors, if any are employed on the part of this state, shall each recelve for his or their services, five dollars for each day, he or they may be employed in running the lines aforesaid: And saidcommissioner shall take an oath, well and truly to execute all the duties assigned him by this act, to the best of his skill and judgment, and to render a true account thereof; and his services certified by the Governor, shall be paid out of the public treasury, by virtue of a warrant from the Auditor of Yublic Accounts. Each lajorer and chain carrier, employed on behlaf of this state, shall receive as a compensation for his services, three dollars per day, to be paid by the commissioner, out of any funds which nay be placed in his hands by the governor of this state, for that purpose: And the governor of this state shall have at his disposal, to be drawn from the treasury at his order, two thousand dollars, to be paid in contingent expences, for the purpose aforesaid. Each chain carrier shall be sworn by the or one of well and truly to carry the chain, and render a true account of the distance. But if the state of Tennessee shall refuse to pass an act, 
similar in its provisions, this act shall cease to operate, and have no force and efiect: nor shall any fact or concession therein be binding or obligatory upon the state of Kentucky, in any future discussion of the said boundary line, whether that discussion be legislative or juaicial.

Acts $1815-16$ pp 624

\section{Appendix 26}

1817

An Act for adjusting the boundary line between this state and the State of Rentucky. rassed November 241817.

Whereas great injury may happen, as well to the citizens of the State of rentucky, as to the citizens of this state, from sufiering any part of the boundary line between the two states to remain unascertained and marked: therefore,

Sec. I Be it enacted by the General Assembly of the state of Tennessee, That the line commonly called Walker's line, so far as the same has been run and marked, shall be considered and taken to be the true line between said states.

Sec. 2. Be it enected, That so soon as the state of rentucky shall pass a law agreeing thereto, a direct line from the eastern extremety of the line called Walker's line as marked at Cumberland river to Walker's line at a place called Cumberland Gap, shall be taken and considered the true line between the two states.

Sec. 3 Be it enacted, That this state will provided the state of Kentucky agree thereto, apply to the Executive of the United States to appoint a commissioner to ascertain the true point where the boundary line between this state and the state of Kentucky will strike the Tennessee river on the western bank thereof, and that from said point a line shall be run directly west to the west boundary line of the state of Tennessee, which shall be the line between the two states. 
Sec. 4. Be it enacted, That the Governor of this state shall have full power and authority, whenever he shall receive information that the state of Kentucky has agreed to the appointment of Commissioners on behalf of this state, to superintend the running and marking the said lines.

Sec. 5. Be it enacted, That, when said lines shall have been run and marked, every grant which may have been issued by the state of Kentucky, and which may cover lands lying south of said line, shall be considered as good and valid as if such grants had been issued under the authority of the State of Tennessee: Provided, always, That this section shall not have any affect until the State of Kentucky shall have passed a law containing a similar provision to such grants as may have been issued by the state of Tennessee, and may cover lands lying north of the line.

Sec. 6 Be it enacted, That this state shall stand pledged to pay one-half of the expense of the commissioner who may be appointed by the Executive of the United States.

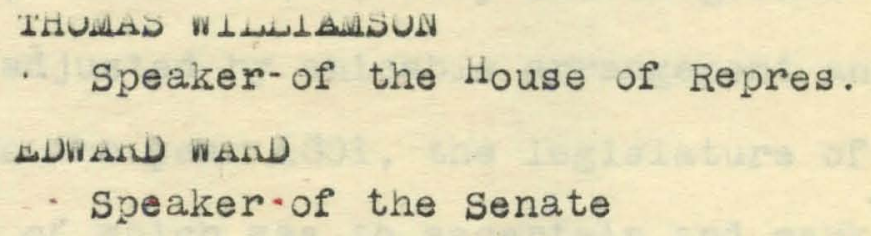

An Act to repeal all laws passed by this state relative to the Southern Boundary Line. Approved Jan. 301818.

1 Be it enacted by the General Assembly of the Commonwealth of Kentucky, That all laws heretofore passed by the general assembly of this commonwealth relative to the boundary line between this state and the state of Tennessee, shall be and the same are hereby repealed, 
2 Be it further enacted, That the southern boundary line of this state shall be and remain on a line running west from the top of Cumberland mountain to the lississippi river, in thirty-six degrees and thrity minutes north latitude, any thing in any former law passed by this state to the contrary notwithstanding.

\section{Appendix 28}

1818 Passed liouse $J$ an 31. 1818 Hailed Congressmen in:

Resolutions relative to the Boundary ine betweun this state and the state of Tennessee.

To the Congress of the United States of America.

The memorial of the general assembly of the commonwealth of Kentucky, respectfully represents, that for many years past an unpleasant controversy has existed between this state and the state of Tennessee, relative to the boundary line between them. Lany attempts have been made to settle the difference to the mutual satisfaction of both states, but hitherto all these attempts have been unavailing; and judging from the past, there remains very little ground of hope that the dispute will be adjusted by amicable arrangement and mutual concession. As far back as the jear 1801, the legislature of sentucky passed an act, the object of which was to ascertain and mark the true position of the boundary line between the two states, according to their chartered limits. This act was repealed at the next session of the general assembly of this commonwealti. In the year 1812 the subject was. again taken up by the legislature of Kentucky, and an act passed authorising the appointment of commissioners, to co-operate with commissioners to be appointed on the part of the state of $\mathrm{T}_{e}$ nnessee, for the purpose of running and marising the boundary line between the two states according to its true position. This act was predicated on a resolution passed by the general assembly of the state of Tennessee, the provisions of which were promptly acceded to by this state. It 
was at this period that the people of Kentucky contemplated a speedy termination of the difierence between the two states. Both parties had assented to the same proposition, and public faith seemed to stand pledged to carry into effect the mutual agreement. But tais fair prospect was soon darkened by the conduct of the state of Tennessee. The state of sentucky saw with regret, that the state of Tennessee would not abide by the terms which she had at first proposed. She abandoned her own propositions, and by the departure defeated the adjustment of the existing difference. The consequence of this conduct on the part of the state of Tennessee, was the passage of an act by the general assembly of Sentucky, in the year 1813, requesting the governor of this state to communicate to the executive and legislature of the state of tennessee the ultimate determination of our government on the subject of the boundary between the two states. By this act of 1813 our executive was requested to sulicit from the government of the state of Tennessee, a recognition of the principles contained in the resolutions adopted by the state of Tennessee, in pursuance of which our act of assembly in 1812 had been passed, and the adoption of the necessary neasures for carrying the same into complete operation; and further, to express to the government of Tennessee, in case of their final rejection of the overdue made by the act of 1813 that the disagreeable necessity of having the contested question of boundary settled by a resort to the means pointed out by the constitution of the United states for the decision of such controversies, would be imposed upon the goernment of Kentucky. The government of the state of Tennessee gave no official answer to the communications made in pursuance of the act of 1813. Her fallure produced a memorial by the legislature of sentucky to your body, asking the interference of congress as the last resort for settling the controversy, all other means having apparently failed, approved by the executive of this state February 1st 1814. During the 
session of the general asgembly of this state in the winter of 1815-16, the state of Tennessee sent a cominsioner to our government authorised to renew the negotiations between the two states on the subject of boundary. He was heard at the bar of the house of representatives. The result was the passage of a law on our part, approved February 10th 1816, the provisions of which in the opinion of this legislature, are liberal, as it relates to the state of Tennessee. The people of this state waited with much anxiety for the meeting of the legislature of the state of Tennessee, after the passage of the act of 1816. It was hoped that the government of Tennessee would not hesitate to accede to all the propositions contained in ouract of 1816; but in this we have been greatly dissappointed. It is true that the legislature of Tennessee took up the subject at their last session, and passed an act concerning it, but its provisions fall very short of those contained in our act of 1816, and are such as cannot meet with the approbation of this legislature. This assembly is constrained to regard the failure on the part of the state of Tennessee, to reciprocate the provisions of the act of 1816, an evincing a disposition to delay the settle ment of the controversy, unless done upon terms degratory to the inteests and rights of Kentucky. It therefore becomes the imperious duty of this assembly to appeal to you $r$ body as the arbiter, under the authority of the constitution of the United States, to point out the mode by which the contest unhappily existing shall be decided. The laws which the legislature of Kentucky has passed on the subject, and to which your is referred for more particular inforination, will prove that our state has not been wanting in exertions to have the difference amicably adjusted. It is conceded on all sides that the true line should run on a parallel of $36^{\circ} 30^{\prime}$ north latitude. The constitutions of the statesof North Carolina and Tennessee both recognize thet latitude as limiting their northern boundary; and in this they coinclde with the charter of King 
Charles II. It is presumed that no objection can be made to the establis ment of the true line, unless it be on account of the effect it will probably have on individual rights to land lying between the said latitude and what is now called Walker's line, to which at present both states exercise jurisdiction. To obviate this objection, the legislation, of sentucky will be governed by the most liberal principles. If the establishment of the true line should operate so as to give more territory to this state, whereby many persons now citizens of Tennessee, living on lands, titles to whlch they have derived by grant from the states of North Carolina or Tennessee, this legislature doth pledge the faith and character of kentucky to ratify all such claims, whereever they do not interfere with claims founded on the land laws of the state of Virginia, or of this state; and where they do interfere, the occupant in all cases shall have the benefit of the laws in force in this state for tine time being, made for the protection of occupying dlaimant, the statute of limitations excepted. The unsettled state of tie line is calculate to have an effect in the formation of new counties which bind on 1t. To particularize all the evils to the state and especialiy to those individuals who have claims to land founded on the laws of Virginia and this state, lying within our chartered limits, and who are zept from the enjoyment of thise rights by the present exercise of jurisdiction over their lands by the state of Tennessee would be unnecessary. Nothing short of the establisnment of the line between this state and the state of Tennessee according to its true latitude, will now compart with the wishes of this legislature; and as it is a right appertaining to our state, which can only be enforced by the supreme court of the United States, acting under the wise provisions of the constitution of the United States, we ask of your body the passage of a law directing the procedings in the supreme court by which one state having a subject of diflerence with another, may have the same 
loyally decided. To efectuate this desirable object, this general assembly ooncur in the following resolutions, to wit;

Resolved by the General Assembly of the Cominonwealth of Kentucky, That the foregoing memorial to congress be adopted as the earnest prayer of this legislature.

Resolved, That the acting governor of this state be, and be it hereby requested to transmit a copy of this memorial and resolutions and coples of all laws passed by the legislature of Kentucky, and all laws and resolutions passed by the legislature of Tennessee aluded to in the foregoing memorial, to each of our senators and representatives in congress, to be by them laid before that body.

Resolved, That our senators in congress are hereby instructed, and our representatives requested to use their exertions to effectuate the object of this nemorial.

Resolved, That the acting governor be, and he is hereby also requested to transmit copies of this memorial and resolutions, and copies of all laws and resolutions passed by the legislatures of this state and Tennessee, to each of the senators and representatives of the state of Tennessee in the congress of the United States.

Resolved, That our senators and representatives in congress be, and they are hereby requested to report to the governor of this state the steps which they may take to effectuate the object of the foregoing memorial, and the result to be by the governor laid before the next general assembly. Acts $1817-18$ pp 576 . State of Kentucky Secretary's Jefice

The foregoing nemorial and resolutions, and the several laws annexed thereto, are copies of all the proceedings and laws passed by the Legislature of this state, and of the last law passed by the regislature 
of the State of Tennessee, on the subject of the boundary line between those states.

Attest: Juin rusa, secretary.

American State Yapers

Vo1. 38 pp 459

Appendix 29

1819

An Act to run the Boundary Line between this State and the state of Tennessee, west of the Tennesse River. Approved Feb. 81819.

Whereas by the ratification of the treaty entered into by faac Shelby and Andrew Jackson, on the part of the United States, and the Chickasaw Indians, the Commonwealth of Sentucky has gained an 1mportant addition to her territory, adjoining the south boundary line below the Tennessee river; and whereas the line, between said river and the Missippi river, has never been run and marked, and it is deemed highly important to have the said line run and marked between said rivers: Therefore

Sec. I Be ic enacted by the General Assembly of the comnonwealth of Kentuciry, That the governor of this comnonwealth, be, and he is hereby authorized and required to appoint two commissioners who shall run and mark the south boundary line of thls state, between the Tennessee and Mississippi rivers, upon a parallel of thirty-six degrees and thirty minutes of north latitude.

sec.2. Be it further enacted, That said commissioners be, and they are hereby authorized to employ such surveyors, chain carriers and markers as they deem proper and necessary, to aid in running and marking said line, to whom the said commissioners shall maxe such compensation as may be agreed upon at the tine they are enployed.

Sec 3. Be it further enacted, That said commissioners shall severally 
receive for t leir services six dollars for each day they may be engaged in the service of the commonwealth, in discharging the duties imposed on them by this act; and they shall make out their accounts ajainst the commonwealth, verified by their own oaths; which accounts, when so made out, shall be paid by the auditor, by a warcant on the treasurer as in other cases.

Sec. 4 Be it furtier enacted, That the commissioners appointed under this act shall be, and they are hereby authorized to draw from the treasury two thousand dollars in advance to enable them with the more facility to discharge the duties imposed on them by this act; for whio h sum the auditor is hereby directed to give a warrant on the treasurer in favor of the commissioners upon being by the governor of their appointment.

Sec. 5 Be it further enacted, That the governor of this comnonwealth be, and he is hereby requested to transmit a copy of this act to the executive of the sta e of Tennessee, and to request the executive of said state to appoint a like number of commissioners, to co-operate with those appointed by the governor of this state, in running the said line as aforesaid.

Sec. 6 Be it further enacted, That if the executive of the state of Tennessee should within two months notify the executive of this stale, that the commissioners are appointed on the part of the state of Tennesse to co-operate with those appointed in virtue of this act, to run said line as aforesaid, it shall be the duty of the executive of this state to inform the commissioners appointed under this act, the names and places of residence of the commissioners appointed by the executive of Tennessee; which infornation, the governor of Tennessee is respectfully requested to give; and the commissioners appointed under this act shall correspond with the commissioners appointed by the executive of Tennessee, and shall $\mathrm{fix}$ on some conve nient time and place, within four inonths froil the passage of this act, for a meeting of the conmissioners of both 
sides; at which meeting such regulations shall be adapted as the commissioners may think proper, for effecting the object of running and marking said line as aforesaid.

Sec. ' $\mathrm{Be}$ it Purtier E nacted, That if' the execut ve of Tennessee should refuse or fall to appoint commissioners to co-operate with those appointed unier this act, or if the commissioners appointed by the executive of the state of Tennessee should refuse or fail to co-operate with those appointed under this act, in either case it shal $\perp$ be the duty of the commissioners appointed under this act to proceed and run and mark the said line as aforesald, and shall report their proceedings to the executive of this state, to be by him laid before the next general assembly of this commonwealth. Acts $1818-19$ pp 119

Appendix 30

To his Excellency Joseph M 'Minn, Governor of the state of Tennessee. Frankfort, Apri1 141819

Sir: Un the 12 th day of February last, 1 addressed a letter to you by mall in compliance with an act of the Legislature of Lentucay, passed at their last session; but not having recelved any answer to that communication, and being desirous to know your views on the subject, so far as they were requested, I take the liberty of addressing you again, presuming that ray former comnunication has miscarried. I have the honor to enclose to jour excellency a copy of the act whicn is entitled,"an act to run the boundary line between this state and the state of Tennesseg and west of the Tennesse river," and also to inform you that pursuant to the said act, I have appointed Robert Alexander of this place, and general John Adair of Mercer county in this state, commissioners on the part of this commonwealth to run the sald line according to the directions of said act.

I have in further compliance with the said act, to request jour ex- 
cellency to appoint two commissioners on the part of Tennesse to co-operate with those I have appointed on the part of this commonwealth in running the sald line.

Your excellency will please to notify meas early as is convenient of the appointment of comissioners on your part, with their names and places of residence, if the authority vested in you, and opinion of your excellency, should accord with the views of the legislature of kentucky.

I have the honor to be,

With high respect, your most obedient

(signed)

Gabl. Slaughter

\section{Executive Office}

Murf reesburough, Tennessee, 3d Way 1819

Sir--By the mail this morning I had the honor to recelve your excellency's communication of the 14th ultimo, covering a copy of a act of the general assembly of the cominonwealth of kentucty, on the subject of running the boundary line between that atate and the state of Tennessee, west of the Tennessee river.

The objects had in view by the legislature in passing the acts are highly and equally interesting to the citizens of either state and had a session of the general assembly of the state of Tennessee intervened since it became necessary to act upon the suject, ample provision would doubtless have been made for an amicable and full adjustment of boundary, (at a time suited to the convenience of all concerned) at least to the extent now proposed by the commonwealth. But the general assembly not anticipating the event, I am left in a situation which compels me to protest for the present agalnst all further progress in any measure which is connected with the gettlement of linits on the line proposed. Should the comrissioners appointed by you, now go into the execution of the duties required of them, the interests of Tennessee may be materially affected in a transaction, where, from pecullar clrcumstances, 
She has not had an opportunity of being heard. To obviate, therefore, any difficulty which might hereafter arise, to disturb the good understanding of the sister states, I would suggest to your excellency, that the delay of a little more than four months will put it in the power of Tennessee to say how far she will go in the execution of a measure, the design of which, must be, the prevention of all plausable pretext for mutual recrimination or complaint. The legislature of this state will be in session on the third Londay in september next, the subject can be immediately brought before them, and I persuade myself that they will, without delay, give an earnest of their sincere desire to do whatever may be reasonable and right.

It appears that towards the close of the last session of congress, an attempt was made to direct the president of the united States, to appoint an artist to ascertain and run the line now proposed to be run by the two states. The measure, I an authorized to believe, failed of success, more from the pressure of business of a general nature, than before congress, than from any opposition arising from prineiple or expediency; and it may be, that although an express legislative direction is wanting, the president of the United States might still on one joint application, appoint some artist to act alone, or in aid of such persons as might attend on the part of the respective states.

You will if you please, advise me of the determination of your excellency on the subject of postponement and application to the president.

I have the honor to be, very respecifuly, your excellency's ob't. humble serv't, Jos. L'Linn

Appendix 31 
An Act to adjust the boundary line between this state and the state of Kentucky, November 23.

Whereas doubts have arisen as to the true line of boundary between this state and the state of Kentucky; for remedy whereof, and to preserve those friendly relations that ought to subsist between said states.

Sec. I Be it enacted by the General Assembly of the State of Tennessee, That two persons be appointed by joint ballot of both branches of this Legislature to attend the next ensuing wegislature of the state of Ientucky, as commissioners on the part of this state, for the purpose aforesald, and the said persons are hereby authorized and empowered, to confer, and agree with the Legislature of kentucky, or with such persons as they may appoint, as to what shall hereafter be considered the line of boundary and separation between the said states.

Sec2. Be it enacted, That whatever may be agreed on by the persons hereby empowered on the part of this state, shall be as valid and binding, as the sane had been agreed to by the General Assembly of this State, and shall upon the ratification of the same by the Legislature of Kentucky, forever thereafter, be considered and held the true line of boundary and separation between the states of Tennessee and sentucky. sec. 3. Be it enacted, That if said persons so as aporesaid empowered cannot arive at any certain positive agreement, in relation to said line, and at an adjustment of every doubt and difficulty incident thereto, they are hereby authorized and empowered to any mode of adjustment which to them may appear right and proper.

sec. 4. Be it enacted, That the state of Tennessee will not, unt11 an adjustment can be had, permit any location or entries to be made north of a line run during the present year by commissionerson the part of Nentucky west of Tennessee River, nor in any manner perfect titles thereto; provided always, that the state of Kentucky, will by law enact, that no location or entry, shall be made south of where Walker's line 
would run, if extended west of said river Tennessee to the Hississippi where the latitude was marked by the commissioners formerly appointed by the state of Virginia, and that she will in no wise perfect any title or titles south of said line.

Sec. 5. Be it enacted, That the fourth section of this act shall take effect and be in force, so sson as the Governor of this state shall be advised by the Governor of Kentucky, that by said state, a similiar law has been enacted.

Sec. 6. Be it enacted, That each of the commissioners by this act directed to be appointed, shall be entitled to receive the sum of seven dollars for each day he may be necessarily engaged in the duties of his appointment, and the same sum for every twenty-five miles he shall travel, to be paid by either of the Treasurie of this state, upon a statement of his account.

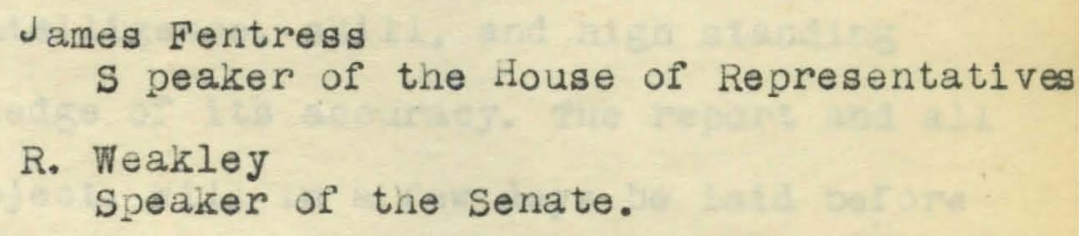

1819

Acts Tennesse Chapter 55

November 27

Sec. 6. Be it enacted, That it shall be the duty of the commissioner, to be appointed under the provisions of an act passed at this General Assembly, entitled, "An act to adjust tie boundary line between this state and the S tate of kentucjy", to apprise the Governor of this State of the result of their mission, and if it shall appear, that they have falled in arriving at an adjustment of the difference in any manner in that act recited, that it shall be the duty of the Governor forthwith to cause the northern boundary line of this state to run out and plainly marked, from the east bank of the Cumberland River on Walker's line, to the corner made by sald walizer on the east bank of the river Mississippi; which line so run and marked, shall be the northern 
bounlary of the Twelfth and Thirteenth Districts of the surveyors west of the river Tennessee.

\section{Appendix 32}

Extract from Gov. Slaughter's Wessage Dec. 01819

rursuant to a law of the last session, I invited the governor of the state of Tennessee, to appoint comissoners on the part of that state, to, co-operate with those appointed on the part of this commonwealth, to run and mariz the boundary line between the two states, west of the Tennessee river.--This he declined, sugbesting a want of authority, and requested a postponement until the legislature of Tennessee could act on the subject. The law being imperative, I deemed it my duty to proceed, and appointed Robert Alexander and Luke Lunsell commissioners, who, with the aid of Col. William Steele and Richard Fox, surveyorg, have performed the work-- and the intelligence, skill, and high standing of these gentlemen furnish a pledge of its accuracy. The report and all the papers relating to this subject, will in a lew days be laid before you.

wessage of the Governor, Journal of House of Representatives The Commisioners appointed by virtue of an act of the last session of the general assembly entitled "an act to run the boundary line between this state ani the state of Tennessee, west of the Tennessee river," Report that believing from the tenor of the above inentioned act, it was the wish of the legislature that the contemplated line should be run and marked as early as possible, they proceeded without delaj to take the measures necessary for accomplishing it. A boat was hired for the conveyance of the instruments, a contract made for the subsistance of the persons to be engaged, and an agreement entered into with the surveyors for themselves and the chain carriers and markers, that were supposed necessary. For the purport of these the commissioners beg leave to refer to the acjount and vouchers which have been filed with 
the auditor of public accounts, and which contain a statement of the monies disbursed in conformity with the agreement in question.

The boat set out from Frankfort on the bth of $J$ une and arrived at the mouth of the Tennessee on the 19th. It was thought desirable to procure for the information of the legislature and yourself, a correct survey of as great a portion of the outline of the late purchase within the limits of this state, as the speady performance of the principal duty of the commissioners would jermit. The surveyors were therefore employed while the boat ascended the Tennessee, in meandering the river from tts mouth. At the distance of 52 miles and 132 poles from the mouth, the comnissioners landed for the purpose of determining the position of the line; the observations taken at this station are annexed to this report. The distance was found to be more consderable than had been supposed, and as the cominissioners were desirous of procuring a more steady support for the instruments than this station afforded, another was sought for and found $53 \mathrm{~J}$ poles above it. The observations taken at this second station accompany those taken at the first; and from the result of the two sets, the commencement of the line to be run was marked on the west banz of the Tennessee river 2'55"4 or 1075 poles above the second station, as specified in the report of the surveyors which is inclosed. Observations were also made at these stations for determining the variation of the needle, which was found to be $7 \frac{4}{4}$ east of the meridian. The surveyors were instructed to neasure and mark a line due west from this point to the Mississippi river. They procoded according with their assistants to the performance of this duty, while the commissioners descended the Tennessee, the Unio and Mississippi, to ascertain the point upon the latter at which the line should terminate. After some observations for determining nearly the situation of this spot, they finally landed their instruments on the east banis of the river about two miles above the island commonly called No. 10. The 
observations taken at this last station, are annexed to this report. Other observations were also made here for deternining the variation of the needle, which was found to be the same as on the Tennessce. After they were completed, the commissioners were joined by the surveyors and their assistants. The obstacles and privations encountered by these gentlenen in their progress had been such as to delay their arrival beyond the time expected, and to exercise their patience, and fortitude pretty severely-their direct course had been intercepted by ponds and lakes, which after many fruitless trials were found impassable; a line was therefore marked back from this station to the point at which these ponds and lakes again met them, in the manner specified in their report. They then proceeded on a due west direction, crossing the Hississippi river, a point of the dissouri territory and the dississippi a second time, to the plantation of Charles Hamilton, on the neck of land opposite to New Madrid, and from thence the line was cont nued to the opposite side of the said neck of land as specified in the report of the surveyors above men ioned.

On the 26 th of July the comnissioners completed their business and the party returned home.

From the account before nen loned, it will be seen that the total expense incurred by the state froin this undertaking ammounts to $\$ 4,023.25$, whether the sum exceeds or not what has been considered the probable expenditure on the occasion, the commissioners are not able to say. They believe however, if it were found necessary to jerf orm the same duty a second time with the same hands, it could not now be done for a much larger sum.

The foregoing is respectfully subritted by,

Robt. Alexander)

L. Wunsel1, Comn'rs.

Journal House of $R^{e}$ presentatives, pp $46 \quad 1819-20$ 
Appendix 33

Correspondence I

The Tennessee Commissioners propose an adjustinent on the following terms.

Walker's line as understood and acted upon by the two states, and their respective officers and citizens, to be the line between the states, east of the Tennessee river. Alexander's line from the Tennessee to the place where Alexander's line first strikes the Mississippi; the centre of the Tennessee river to be the jurisdictional line, from Walner's up to Alexander's line. The Islands (if any) to be with the state of Tennessee. All North Carolina grants north of Alexander's line to be valid, if not interfered with by a Virginia claim. The North Carolina grants must be prior to the cession act, or the claim must have originated before that time; and no grant shall be valid unless the same would be so by the laws of Tennessee; A similar provision for Virginia clains east of the $T_{e}$ nnessee river,

$$
\begin{aligned}
& \text { F. Grundy } \\
& \text { W. ๖. Brown }
\end{aligned}
$$

\section{Append1x 34}

Correspondence 1 I

Madison House, January 8 th 1820

Gentlemen,

Your note handed to us this morning containing the only written propositions in relation to the boundary line between our respective States, which we have had the honor to receive from you, is before us. We have had reason to expect from the various conversations of the free and easy sort which have taken place between us upon this subject, and particulariy froin that of this morning, that the propositions which you contemplated naking in writing, were predicated upon the final rejection by you, of the several propositions made by us in those conversations, 
and that your $\mathrm{n}$ te would import in substance jour ultimatum.

As the note is without any such written indication, we have to request, that you will in answer to this, inform us, whether these propositions, or any of them are to be considered as still open to discussion, or as finally rejected by you,-- and whether your note contains in substance your uttimatum. We are particularly solicitous to know, if the following of the propositions which we had the honor to make to you verball, is to be considered as finally rejected by you, viz; That though consclous that the parallel $36^{\circ} 30^{\prime}$ north latitude was and is the true and only legitimate boundary line between the two states; we would, (influenced by a spirit of conciliation) agree that the line run by Walker should be the dividing line between the two states as far as it was run in a western direction, viz: To the Tennessee river, and that the state of Tennessee should posess the soll and exercise its jurisdiction between the line and the chartered line aforesaid-if(influenced by the same spirit) jou would asree to a line to be run as far south of the line lately run by Alexander, \&c. and parallel thereto, comencing on the west bank of the Tennessee river, running thence west to the lississippl river, as would give to Kentucky, either according to the criterion of value or of quantity, an equivalent for the land lying between Walker's line and the true chartered line -or that influenced by the same spirit, we would afree that a line run from a point due south or due north from the mouth of Oby's river, to the parallel north lat. $36^{\circ} 30^{\prime}$ and thence due east, should be the dividing line from that point eastwardly; and that the line lately run by Alexander, \&c. should be the dividing line between the two state west of the Tennessee river; and that the line run by Walker should be the dividing line between the point where it strikes Tennessee river, and the point where it must be connected, by a line at right angles therewith, with the chartered line nortin or south of 
Oby's river as before stated.

Your explicit answer to the foregoing matters will enable us to act more dispatchfully upon the contents of your note.

We have the nonor to be, Lost respectfully,

Your obt. servants

John J. crittenden

John Rowan.

Appendix 35

No. III

Gentlemen:

Mansion House, January 8th 1820

In answer to your note of this day, we take the liberty of stating that we wished you explicitly to understand, that in the proposition we handed this morning, the Tennessee comnisioners had determined to cede no territory south of Alexander's line; much less could it be agreed to admit an extension of the jurisdiction of sentucky into wh t is now considered the settled parts of Tennessee, east of the mouth of Uby's river. That territory is all granted where it is of value, and Kentucky by such session would only acquire the government of an unwilling people, which cannot we presume, be desired by any free government. We now say tnat our note of this morning contains substantially our ultimate proposition.

We have the honor to be,

With great respect,

Your humble servants

Felix Grundy

WII L. Brown

Appendix 36

No IV

Gentlemen,

Hansion House January 81820

lour note in answer to ours of same date has been received 
and considered. The propositions made by us beins explicitly rejected, we have only to inform you of our determination in relation to those submitted by you, in your note. On this subject the sentucky conmissioners differ: one of them would accede to your propositions with some modifications-the other cannot. The concur rence of both being necessary to make any compact, and we differing in opinion, as to your ultimate propositions, there remains no hope of concuring in any terms of adjustment; but as we are extremely desirous of seeing all disputes and controversies between our respective states amicably terminated, and as to effect that object, we are disposed to use all means with which we are invested by law, we propose that all natters of dispute and controversy about the boundary of our respective states, be referred to the final decission of Arbitrators of distinguished character and talents, and who shall not be citizens of either Virginia, Carolina, Tennessee, or Lentucky, or of any state forned out of Territory origionally chatered to Virginia or carolina, If you would accede to this proposition we shall be prepared at any tine to proceed with you to the election of any number of Arbitrators that we may agree upon, and to nake other necessary arrangements.

$$
\begin{aligned}
& \text { We have the honor to be } \\
& \text { Very respecteully, } \\
& \text { Your obt. servants } \\
& \text { John J. Crittenden } \\
& \text { John Rowan }
\end{aligned}
$$

Appendix 37

No. $\mathrm{V}$

Gentlemen,

$$
\text { Mansion House, January } 811820 .
$$

$$
\text { your second note of this day has been received, and we are }
$$
sorry to learn that our proposition has not met with your united approbation. It would have afforded us much pleasure to have adjusted 
the controversy between the two states, and to have affected that desirable object with you, who were selected yo jour state to act with us, would have increased our satisfaction had you boun ooncurred in acceding to the leading points in our proposition. Modification in minor points would have been expected, as the result of the joint suggestions and efforts of both parties, and we have no reason to believe that any difficulty would have occured.

You wish us to state whether we are disposed to refer the final decision of the question to Arbitrators, \&c. We answer, that although we have entire confidence in the claims of Tennessee, we foresee much difficulty, expense and delay attendent on tre cause sug,ested. We therefore decline to act at present under that portion of our powers which contemplates a decision by Arbitrators.

$$
\begin{aligned}
& \text { We have the nonor to be } \\
& \text { Respectfully } \\
& \text { Your humble servants } \\
& \text { Felix Grundy }
\end{aligned}
$$$$
\text { Wm. }
$$

Appendix 38

No. V1

$$
\text { Wansion. House January } 9 \text { th } 1820
$$

Gentlemen,

Your note of the 8 th instant has just been received. To that part of it which expresses the regret felt by the Tennessee comisisioners, that their ultimate proposition as not met our united approbation, we answer, that their regret is most sincerely reciprocated on our part, not of a less affecting character. We reelprocate also the sentiments of pleasure whlch the Tennessee commissioners are pleased to signify, the final adjustment of the unhappy dispute between the two states would nave aftorded to them; and we feel flattered by, and most cordially reciprocate the sentiment, that the pleasure would have been 
enhanced by considerations of a personal sort in reference to the commissioners. In relation to that part of your note which purports to be in direct answer to so much of our note as proposed a reference of all matters in dispute between the two states in relation to the bound ary Line, to Arbitrators, we.,-permit us to express our regret, that you decline to act at present under that portion of your powers which contemplates a decision by Arbitrators, and to assure jou that at any future time when you may judge it expedient to exercise that portion of your powers, you shall find us zealous and prompt to promote by our concurrence, that very desirable mode of adjustment. We feel authorized to say, that the delay, expense and trouble to which you refer as incident to thiat mode, will form no obstacle to its adoption by the state of Kentucky, as it forms none with her commissioners, such is the zeal of amity felt by them and their state towards the state of Tennessee and her commissioners. Indeed the state of Kentucky has displayed the zeal of amicable feeling above alluded to by binding herself in the ac which confers the power we are now exerclsing ( in the event that every other mode of adjustment falled) to abide by the decision of Arbitrators to be chosen by us. That event has happened, unless some node as yet annoticed, and to us unknown, may have occured to the Tennessee commissioners, and by which they are influenced to decline at present to act under that portion of their powers which contemplates a decision by Arbitrators, Should such be the fact, we will hasten to examine it with them and make the experiment at the moment they shall please to suggest or disclose it.

We have the honor to be,

With great respect gentlemen,

Your most obedient servants, John J. Crittenden 


\section{No. VIf January 9 th 1820 .}

Gentlemen,

Your note of this day is before us, We sed no reason to change our opinion in relation to a reference to Arbitrators; we therefore decline that mode of adjustment at this time. No terms of adjustment unknown to you have occureed to the Tennesse commissioners, nor should we feel Justif ed in offering a proposition more likely substantially, to produce an amicable arrangement heretofore presented

We have the honor to be

respectrully

Your humble servants,

Felix Grundy

Wm. ᄂ. Brdwn

Appendix 40

No VIII

Lansion House January 10 th 1820

Gentlemen,

In your note of last evening in answer to the one addressed by us to you on yesterday, we note the following paragraph, viz: "We see no reason to change our opinion in relation to a reference to arbitrators; we therefore decline that mode of adjustment at this time" We were authorized by our state to propose, in the event which has happened, a reference of the dispute between the states in relation to the boundary line, to Arbitrators. We made you a direct proposition to that effect; your answer purports as we understand its phraseology, not a rejection of the proposition, but a declension of it at this time. We feel it our duty therefore to inform you, that our powers are unlimited as to time, and that whenever you shall have deterained to embrace or reject the proposition definitely we will be ready to receiv e your determination, and in the event of your acceding to it, happy 
to confer tith you, as to the adoption and arrangement of the means best calculated to bring it to a dispatcheul and effectual issue.

$$
\begin{aligned}
& \text { We have the honor to be } \\
& \text { Gentlemen most respectfully } \\
& \text { Your most obedient servants } \\
& \text { John J. Crittenden } \\
& \text { John Rowan }
\end{aligned}
$$

Appendix 41

No IX

$$
\text { Lansion House, January loth } 1820
$$

Gentlemen,

We have received your note of this morning, and in ieply state, that we know of no arrangement other than that already proposed on the part of Tennessee, which we are prepared to offer or adopt. In answer to the proposition already made by us, we are informed the Nentucky commissioners do not agree; and we are induced to hope from the nature of the adjustment submitted by the Tennessee commissigners, that when the same shall come under the consideration of the legislature of Kentucky, it may be adopted as the basis of a settlement of this unhappy difference- A speedy determinati $n$ of this difference we know to be the earnest desire of all the cominissioners, as well on the part of Kentucky as Tennessee. And we fel confidentially assured from the earnest wishes for such a consumnation expressed by both the Lentucky commissioners, that an accomodation offered in this manner, will give them much pleasure. We must again express our deep regret, that the commissioners on the part of the two states, have not been able to settle this difference between sister states so intimately and necessari 1y connected by every tie of situation and interest: And this regret is greatly increased by the high personal regard entertained for the gentlemen engaged in this negotiation on the part of sentucky. 
Accept gentlemen,

Jur most sincere assurance of respect

W. ᄂ. Brown

F. Grundy

P.S. We shall lose no time in giving to the executive of rentucky information of the fallure of this negotiation, which we consider as closed, between the Kentucky and Tennessee commissioners.

Your most obedient,

Wm. -. Brown

Fellx Grundy

Appendix 42

To the honorable Senate and House of $R^{e} p r e s e n t a t i v e s$ of the General Assembly of the Commonwealth of sentucky.

John $J$. Crittenden one of the cormissioners appointed by your honorable body, to meet and cunfer with the commissioners appointed on the part of the state of Tennessee, and with them to "agree upon settle, and determine the boundary line between said states, "\&c. respectfully reports:

That your comissioners proceeded to the task assigned them with a deep sense of its responsiblity, and an earnest zeal to accomplish the purposes of their appointment; and it is with great and mutual regret, that they have now to communicate the result of their unsuccessful negotiations. -A regret which is increased by the consideration, that this unfortunate issue is owing to a disagreement in opinion between ourselves. As the correspondence which has taken place between your commissioners and those of Tennessee contains the propositions made by both, and as that correspondence will be herewith communicated to the legislature, it is unnecessary nere to repeat its contents.

The comissioners of Tennessee rejected, or declined, all the propositions for a settlement which were made by us.-Those submitted 
by them, ( and which will be found in the correspondence mentioned above, contemplated two objects: The establishnent of a boundary between the two states-and arrangements concerning the titles of individuals to lands, that might be thereby affected. In relution to the firgt, and most important object, theyproposed that "Walker's line as understood, and acted on, by the two states and their respective officers and cltizens, be the line between the states, east of the Tennessee river, Alexander's line from the Tennessee to the place where that line first strikes the Mississippi-the centre of, the Tennessee river to be the jurisdictional line from Walker's up to Alexander's line, the Islands, (if any) to be in the state of Tennessee."

In relation to the second object, they proposed that," all North Carolina grants north of Alexander's line, should be valid, if not interferred with by a Virginia claim. The North Caoolina grants must be prior to the cession act, or the claim must have originated before that time, and no grant shall be valid unless the same would be so by the laws of Tennessee; a similar provision for Virginia clalms, east of the Tennessee river."

These were stated by the Tennessee commissioners to be tineir ultinate propositions, and in substance, the only terms upon which they could come to an agreement and settlement of the matters in controversy between the two states-and on these propositions your commissioners were divided in opinion. Mr. Rowan objected decisively to the proposed boundary. The undersigned was willing to have acceded to it. Disagreeing upon this principal, and most material points, the incidental propositions which related to the claims of individuals, were not discuseed, or much considep ed by your commissioners. The undersigned entertained some doubts about their power to nake stipulations concerning those clains.-But if such were to be made, he thought that those proposed by the commissioners of Tennessee ought to be modified. These conslderations were, however, 
unimportant, as your commissioners were divided upon the main point, upon which their ooncurrence was necessary, to the making of any compact or settlement. The Tennesse comnissioners were notified of the result of their propositions, andas the only remaining alternative in which they could concur, your commissioners proposed to them, that tiee controversy between the two states, should be referred to the arbitration and final decision of any number of distinguished citizens of the United States, to be mutually chosen, and to be selected from states that could have no interest or bias in the present contest. This proposition was also declined by the $\mathrm{T}_{e}$ nnessee commissioners-and here our negotiations with them terminated. In order, however, that the legislature may have amples infornation on this subject, it may be proper to add, that in subsequent conversations with the commissioners of Tennesse, they expressed themselves perfectly willing to accede to any modification of their propositions that would render them more satisfactory, without essentially changing them; and particularly that they would agree that the Tennessee river, from the point at which it is intersected by Walker's line to the point at which it is intersected by Alexander's should be subject to the common, and concurrent jurisdiction of both states, and they would make any alterations in their propositions which related to private claims, which we nore satisfactory and reciprocal: Or that if it was preferred by Kentucky, they would walve all stipulations and engagements about private claims, and leave individuals, without prejudice, to assert and pursue their rights in any lawful way they might think proper. From the concilitary temper displayed on this part of the subject, no doubt can be entertained, that all natters might hate been satisfactorily adjusted, if your commissioners could have agreed upon the boundary of the two states, as proposed by the comnissioners of Tennessee.

In differing with his more able and enlightened colleague, tne 
undersigned has experienced the deepest and most sincere regret.- And he feels so sensibly how much the burthen of his responsiblity has been thereby increased, that he hojes, without being obtrusive, he may be allowed to suggest very briefly, some of those views and considerations, which have influenced his conduct. He will not at empt any elaborate argumentation upon a subject with which your honorable body is so well acquainted; nor will he attempt to trace minutely the history of the controversy between sentucky and Tennessee.

The territories which from those states origionally belonged to, and composed parts of, the states of Virginia and North Carolina, and by the charters of these latter states, they were divided throughout their whole western extent, by a line to be run upon the parallel of $36^{9} 30^{\prime}$ north latitude. In the year 1779 and 1780 Walker and Smith, acting under the authority of and by the direction of the state of Virginia, ascertained this latitude, as they supposed correctly, and run a line upon it, from a point east of the Cumberland uountain as far westward as to the Tennessee river, marking it at intervals. Tnis line has ever since been notorious by the name of Walker's line. And it is now discovered beyond any reasonable doubt, that Walker was mistaken in his observations, and that his line is some miles north of the proper latitude. The territory lying between that line and the latitude of $36^{\circ} 3 \mathrm{~J}^{\prime}$ north, is the subject of controversy; and the question is, whether that line, or that latitude, forms the proper and legitimate boundary between the two states. Kentucky has insisted upon the latitudinal boundary, and Tennessee contends that walier's line has been so far recognised and confirmed, that it cannot now be questioned or disturbed.

Years of controversy have probably had no other effect than that of confirming both parties in their opinions and pretensions-and the controversy of years to come would have no better effect sovereigns 
are rarely convinced against their interest.

Un this subject, therefore, the undersigned has not so much oonsidered what was the abstract or wrong of the present controversy. He considered what was the best that could probably be done under esisting circumstances, and what was the wisest, the most politic, and magnanimous course that Kentucky could jursue. Upon the mere question of abstract right, if the opinion of the undersigned was matter of any importance, he would say that in strictness that right was with sentucky. But he will not disguise that it appears to him, tiere are many circumstances that mitigate this right, that plead against its rigorous assertion, and address themselves strongly to our justice and our generosity. Walker's was a line of demarkation made by those under whom we claim, made by our parent state of Virginia, who in the next year after its completion, recognised in it the most emphatic manner as the limit of her territory (see act of 1781 lst Litt.432.) Since that period, as far about the space of forty years, it has been observed and respected by all, as the line of division both of territory and soverignty. North Carolina held and governed, according to that boundary So also did the United States after the cession of Carolina. And Tennessee when forned into a state in the year 1796, only succeeded to the same possession. She has been gulity of no encroachment that can irritate our pride, or excite our resentment. Virginia in effect ylelded the possession when she caused Walker's line to be marked as the limit of her jurisdiction. The contested territory has been long ago peopled and organized and incorporated with the state of Tennessee. Walker's line is the basis upon which her counties have been formed and laid off. Towns have been established with reference to it; and with few exceptions it has guided and regulated individuals in both states, in their locations and appropiations of land. The effect of a change of this boundary for only a few miles further south, would be 
to confound and endanger individual rignts-to dismember counties, disturb munlcipal regulations-and coerce a reluctant people, indentifled in feeling with the state of Tennessee and familiar with her laws into a sort of vassalage, or unwlling submission to our government. Jught all these considerations to be sacrified to the acquisition of a strip of territory, of a few miles in breadth along our southern border? To the undersigned they appear powerful and persuasive to induce us to forbear our right, and to confirm the old and long respected boundary. The little acquisition of territory which might be obtained, is not necessary to the dignity and consequence of Kentucky. What then are the great advantages to be derived from 1t? Are there any vacant lands there, the sales of which might replenish the public treasury? No, all that were fit for cultivation, or of any value, have been long since granted out to individuals. And if the territory was on this day transferred to Kentucky, her justice and her honor, would compel her to ratify the claims of its inhabitants, derived from North Carolina and Tennessee. Would she commence her government there, by selzing and confiscating, as it were, the lands of individuals? Surely she would not. All golden dreams then, on this subject vanish 1 into nothing. We should acquice nothing more than the mere right to Jurisdiction over the disputed territory and its reluctent and unwilling inhabitants, who would long feel themselves as vassals or alien s. Republican sentucky could not take much pleasure in such acquisition.Why then should we contend perteniciously, for it, through all evils and inconveniences? Are we stimulated to the contest only by the cold and unfriendly pride of power and sovereignty? This dark and unsocial spirit, that stands to high for question, or for compromise, is wholly uncongenial with the principles of our government, and the relations which bind together the states of this union. Confidence, friendship, concession and compromis, laid and cemented the foundations of our 
general government, and by them alone can that government be preserved. What $f$ ine and illustrious examples on this subject have been set before us by Virginia and Carolina! What vast and valuable territories were ceded by both to the general government.' To the magnanimous policy and bounty of Virginia, Nentucky is indebted for all her fine territory, and for her existence as an indipendent state. And Tennessee is in like manner indebted to North Carolina. All these vast concessions were made in the pure and disinterested spirit of patriotism, and for the purposes of peace, friendship, conciliation, and the good of the whole republic. And does it now become the descendents of these noble states, to wrangle for years about the little subject of this present controversy?To talk in high sounding terms of sovereignty and of sovereign rights, while the "still small voice" of peace and concilliz tion, is unheard or unheaded?

But suppose that all the considerations which have been ofiered above, are insufficient and unavaling, to induce kentucky to forbear or yleld her, claims-is it in her power to enforce that right? Tennessee is in full possession, and believing it to be rightrul, will not surrender 1t. How will you disposess her? By arns you would not do it, and by law you cannot. Kentucky has, for about ten years past, repeatedly appealed to congress to pass a law prescribing a mode for the trial and adjudication of such controversies, by the supre me court of the United States.-Congress has refused to do so. It will not mark out the lists in which contending states are to engage. To your urgent applications, Congress has constantly answered,"compromise your disputes and beat peace, "The undersigned is convinced that no ho je is to be entertained of the interposition of the general government. If then we refuse to compromise, where is our remedy? We have none. What is the value of our naked abstract right? A right without a remedy. There is nothing in 1t. Nothing that can even gratify the idlest pride of 
sovereignty. There may, however, be some magnanimity displajed in making a voluntary sacrifice of it to the peace and harmony of the two states. By acceding to the terms proposed by the comissioners of Tennessee, we should have obtained quiet and undisputed possession of all the territory which we claim west of the Tennessee river, and which it is much to be apprehended, will otherwise become the scene of active controversy, and dangerous collission, between the two states. We should have removed every cause for and occasion for future discord, and restored to perfect tranquility and harmony, two states intimately united by political ties, by local situation, by sympathy and congeniality of character. These surely deserve to be regarded as important and influential considerations. If the present opportunity of settling all their difference $s$ is allowed to pass away, where it may be asked is to be the end, and what the result, of future controversy? Upon what grounds are we to expect hereafter greater advantages than those now offered to us? Experience and the history of the past, refuse such expectations; and it seems unwise to permit faint and uncertain hopes tourge us on to the certain evils of further contention.

Upon the whole the undersigned has not been able to perceive any advantage likely toresult to Kentucky, from a protraction of this disagreeably controversy. He considered it as worse than useless to hold up in terrorem, our barren right, to be brandished for a few years longer in vexatious contest, and then to sink into thet oblivion to which time will eventually consign every right that is not accompanie by 1 ts proper remedy.

Influenced by these considerations, the undersigned was willing to agree upon the boundary proposed by the commissioners of Tennessee. He could not doubt the power of the states to compromise their conflicting claims, and he believed that your act of assembly was intended to invest your comissioners with that power. He was anxious to see all 
matters of difference amicably settled, and he would have felt much pride in being instrumental, in the humblest degree, to the accomplishment of such an object. He trusts, however, that these personal feelings have been held in proper subordination to that superior duty and attachment which binds him to his native state of Sentucky; and that in acceding to the terns proposed, he did not commit either her real interest or honor. The undersigned begs leave to tender to your honorable body his sincers acknowledgements for the honor conferred on him. by placing him on this important commission. And although he and his colleague have been successful, he jet hopes that the superior wisdom of your honorable body may be able to accomplish all the concilitary purposedfor which they were appointed.

He has the honor to be,

Wi th great respect,

Your obedient servant

$$
\text { John J. Crittenden }
$$

Appendix 43

To the honorable, the Senate, and House of Representative of the Cominonwealth of Kentucky.

John Rowan, who was honored by the Legislature with the appointment of comissioner, in conjunction with John J. Crettenden, Esq. to confer with Felix Grundy and William $\sqcup$. Brown, Esqs. commissioners appointed by the state of Tennessee, and settle and adjust with them, the boundary line between the two states, would most respectfully state to your honorable body, that immediately upon being notified of his appointment, he hastened to the performance of the duties resulting therefrom; and in that view arrived at Frankfort early on the morning of the 5 th instant. And according to an arrangenent with wr. Crittenden to that effect, they had on that evening, at the Mansion House an inter- 
view with the commissioners on the part of the state of Tennessee, in which, after the enter-change of credentials, and the appropiate civilities, occurances were made by the Kentucky commissioners, and reciprocated by those of Tennessee, of the zeal which they felt, that the unhappy difference which existed between the two states in relation to their common boundary line, should be brought to a speedy, just, and amicable ternination. The comissioners from Tennessee were informed, in the course of a free and easy conversation which occurred in relation to the topies of their aission, and in answer to an interrogation by them, as to the made in which tile negociation was to be conducted, that in relation to such facts or arguments as might, in the contemplation of either side he thought important as the basis of stipulation, on the ground, either of conclilation or right, a written correspondence would be preferred. A preference to colloquclal conferrence was indicated and pressed on their part; but John Rowan insisted, that the nature of importance of the subject matter, the consideration that two sovereign states were conceived, and the responsibility of the commissioners all pointed to the written, as the preferable mode. Mr. Crittenden annowned his determination to be governed by his colieague in that particular; whereupon it was agreed, that the written mode should be adopted and pursued throushout by the parties re spectfully, in relation to all the matters which they might think essentially material to their case, placed as they might choose, either upon the ground of rigid right, in relation to the legitimate position of the boundary line, or in the view to adjustinent upon the ground of conciliation and mutual concession. Lt was further agreed that before thej enterred upon the written discussion of the subject, they should, by mutual, free, and easy conversations, mitigate as far as it was practicable there by to do it, the rigor of the facts of the case, and so render them more tractable in written discussion. 
Sundry interviews and various conversations which need not be detailed, were afterwards had, throughout all of which it was understood, that discussion, according to the mode agreed upon, was to comnence on their part; that claiming as we did, for the southern boundary of our state, the chartered line of $30^{\circ} \mathrm{s} 0^{\prime}$ north latitude, it behoved them, if they chose to assert any other as the obligatory line, to exhibit it with the proofs of its legitimacy. Early in the conversations above alluded to, they gave us to understand that the line commonly called Walker's line, would be urged as obligatory upon both the states as their comnon boundary, and detailed to us the facts upon which they predicted its obligatory effect. Those facts consisted of several acts of the legislature of Virginia and of North Carolina of a japer purporting to be a copy of the report of Thomas Walker and Daniel Smith to the Virginia legislature, in relation to the manner in which they ran, and the circumstances which attended their running that line. They alledged and seemed to rely upon 1t, as an aditional fact, that walker, after he had run the line aforesaid to the Tennessee river, went from the falls of the Ohio river to the west bank of the fississippi river, and at a point on that bank, at which tie line run by him would have terminated, if it had been continued in the same direction, marked as its western abuttal certain trees. All the facts alledged by them in support, of the legitimacy and obligatory effect of Walker's line, were examined by us, together with the facts and documents in support of the chartered, as the legitimate common boundary line of the two states. This examination was made in the view, not only to ascertain the true state of facts, and the law in relation to those lines, that we might be prepared to discuss, (if the Tennessee commissioners should choose to subject it to discussion) the question of boundary, in that spirit of candor and conciliation which the nature of the subject, respect for ourselves, and above all, a just regard for the character of our state, so emphatically required; 
but that we might in the event of a conviction that the question of boundary was against us frankly concede 1 , and pass on from the ground of right to that of compromise, and occupy it under the influence, and in the spirit in which we had explored the ground of right. The result was a most thorough conviction on our part, that the line of north latitude of $30^{\circ} 3 \mathrm{~J}^{\prime}$ is the ture, legitimate, and only obligatory dividing line between the two states. But the Tennessee comnissioners whether unwiling to express their pretensions, as they related to Walker's line, to the ordeal of written discussion from an apprehension that it could not sustain it or influenced by other views and prospects from which they had more to hope, did not choose to maire them the subject of written currespondence, as will be seen by reference to their first and consequent notes. But before any reference is had to, or comment in ide upon the notes which were interchanjed betwe on the cominissioners John Rowan soliclts the patience of the legislature, while he takes a short, hasty, and he fears immethodical view of the facts and law upon which he preduates nainly the conviction above stated in relation to the legltimate and obligatory line between the two states.

The three charters under which Virginia was clained by the proprietorg there of, were vacated in a proceeding by quo warranta, anterior to the 13 th day of July 1624, on which day the proprietory government of that province ceased, and the regal government thereof commenced; but in the vacation of the charters, the abolition of the proprietory, and the institution of the regal government of that province, the second of the three aforesaid charters remained unaltered and obligatory as to the delineation until it was varied by grants subsequently made to the neighborring provinces, formed the limits of the regal jurisdiction in the government thereof. That chapter bears date on the $23 d$ day of Lay 1609, and purparts to have been made by James 1 . in the 7 th year of his reign, and is so far as relates to boundary, in 
the following words 6. "And we do also of our special grace, give, dec. all those lands, contries and territories,situate lying and being in that part of America called Virginia, from the point of land called Cape, or Point Comport, all along the sea coast to the northward two hundred miles; and from the said point or Cape Comfort all along the sea coast to the southward, two hundred miles, and all along the space and circuit of land lying from the sea coast of the precinct aforesaid, up unto land throughout from sea to se a, west and north west. \&c" The southern boundary of Virginia according to its above receted charter was afterwards on the 30th day of June 1677 by the second charter of Carolina granted by Charles II, to Clorenden \&c. reduced to the paraliel of $36^{\circ} 30^{\prime}$ north latitude; of which charter so much as relates to the northern boundary, there of, which is the southern boundary of Virginia, in in the following words, viz: Know ye, \&c. we are graclously pleased to enlarge our said grant according to the bounds and limits herein after specified, \&c, all that province, territory or tract of land situated, lying and being within our dominions of America extending north and eastward as far as Currituck river, or inlet upon a strait eastwardy into Wyomacis creek, which lies within, or about the degree of thirty-six and thirty minutes of north latitude, and so west in a direct line as far as the south seas, \&c" In the Constitution of Virginia which was formed on the 5 th day of July 1776 , whereby she renounced the regal, and asserted the right of self-government in the character of an independent state, she ceded in the last clause of that instrument, to Carolina, all the territory, jurisdiction and government, to which according to the limits of her above receted charter from Charles, she was entitled, and thereby established and confirmed as the northern boundary of North Carolina and southern boundary of Virginia, the above receited parallel of latitude $36^{\circ} 30^{\prime}$ as the division line, and common boundary between those two states, 
The terms of cession and confermation so far as they relate to this subject, are the following, Viz; "The territories contained within the charters erecting the colonies of Laryland, Pennsylvania, North and south carolina are hereby ceded, released, and forever confirmed, to the people of those Colonies respectively, with all the right of property, Jurisdiction, \&c" When North Carolina renounced the colonies, and by the formation of her constitution, erected herself into a state government, which was on the 18 th day of December 1776 , she recognized and affirmed, in the 25 th article of her bill of rights, the line of latitude aforesaid, as her northern boundary. So much of that article as relates to this subject is in the following words, viz: The property of the soll in a free government being one of the essential rights of the collective body of the people, it is necessary in order to avoid future dificulties, that the limits of the state should be ascertained with with precision, \&c--Therefore, all the territory, seas, waters and harbours, with then appurtenonces, lying between the line above described, and the southern line of Virginia, which begins on the sea shore in thirty-six degrees thrity minutes north latitude, and from thence runs west agreeable to the said charter of King Charles the II., are the right and property of the people of this state, to be held by them in sovereignty, any partia line without the consent of the legislature of this state at any time thereafter directed or laid out, in any wise notwithstanding \&c." Whence it a ppears evident and clear, whether we consult the charter of Charles the II above recited, or tine constitution of the state of Virginia, or that of the state of North Carolina, that the line of latitude North $36^{\circ} 30^{\prime}$ was not only by ordination, but by the consent of all concerned, expressed in the most deliberate and solem form, up to the 18th day of December 1776, the common dividing boundary line between the states of Virginia and North Carolina; and as the states of Tennessee and Kentucky were during that time, the 
former a part of North Carolina, and the latter a part of Virginia, it must at this time be considered as the common dividing boundary line between them, unless it can be shewn that it has been altered by the deliberate consent of the two latter states bef re the erection of the former, or of the former since their erection into gtales; or in other words by the consent of the sovereigns of the territory now embraced in the states of Tennessee and Nentucky. The Tennessee comissioners alledge that the line run by walker and commonly called Walker's line, is of that character, and imports an alteration of the line of latitude, by the consent of the states of Virginia and North Carolina; and of course it is binding upon the states of Kentucky and Tennessee. As evidence of its binding effect, they alledged, that it had been run and marked under the concurrent authority of the states of Virginia and North Carolina, by the joint ageney of commissioners appointed by the states respectively, for that purpose; Thomas Walker and Daniel Smith on the part of the former, and Richard Henderson B. Smith \&c. on the part of the latter; and that it was moreover afterwards affirmed, as run, by those states respectively. It appears that thestate of Virginia in 1778 passed an act the title of which only has been seen by us, which is "An act for extending the boundary line between Virginia and North Carolina", opposite to which it in the margin of the Chancelior's revesal, page 37. where it is found, is the word executed; and that in the year 1779, the state of North Carolina passed an act the title of which is," An act for extending tire boundary line between this (H.C.) state, and the commonwealth of Virginia, by which it is enacted that Richard Henderson, W. B. Smith, \&c. are appointed comissioners with full power and authority to meet with other commissioners from the commonwealth of Virginia, and to proceed to extend and mark the line between the two states; beginnins where Joshua Fry and Peter Jefferson ended their work, and if that be found to be truly in the latitude of 
thirty-six degrees thirty minutes north to run from thence due west to Tennessee or Uhio river; or if it be found not truly in the said latitude, then to run from the said place due north or due south into the said latitude, and thence due west to the said Tennessee or unio river, correcting the sald course at due intervals by astronomical observations; and to report their proceedings to the General Assembly" The Tennessee commissioners connect with the above recited title of the Virginia act, and above quoted provisions of the North Carolina act the copy of the report above alluded to, as one made by Thomas Walker and Daniel Smith to the Virginia legislature, and attempt to deduce therefrom the binding effect of Walker's line upon the state of sentucky. The paper produced by them purporting to be a copy of Sinith's and Walker's report, is in the hand writing of Naj. William Croghan of Jefferson county, Ky. A copy of it marked N. is hereto annexed. From the tenor and lmport of that paper it is evident, that the line claimed on the part of Tennessee, as Walker's line, was not only not run by the concurrent agency of the North Carolina commissioners, or with the consent or approbation of them or any of them, but against their consent, in their absence and under the demunciation of their solemn written protest; that they met Walker and Smith, united with them in ascertaining a point, from which to commence running the line, and run a line from that point, distinct and difierent from that run by Walker, as for west as the top of the Cumberland Mountain, and then desisted and withdrew protesting as aforesald.

It is to be regretted that the act of the Virginia legislature under which Walker acted, is inaccessible. The presumption is, that it provided that the doings of the commissioners, under its authority, were to be reported to the legislature, and approved or negatived as they should be found to have corresponded with, or departed fron, its object and provisions. It is most obvious that the state of Virginia, could 
by no law, which she might enact, in relation to this subject, bind the state of North Carolina without her concurrent or subsequent consent thereto. It is equaliy obvious that the state of North Carolina could not hold the state of Virginia bound by any act of hers to which the legislature of North Carolina had not jielded its concurrent, or subsequent assent. And it is not less obvious that the line run by Walker, if it were not binding when run, upon North Carolina, could not be binding on Vireinia. And if it had been run as far south of $36^{\circ} 30^{\prime}$. north latitude, as 1 t is found to be north of that parallel, the state of Tennessee would be the last to urge its obligatory effect. From the phraseology of the North Carolina act above quoted, it appears to have been the evident intention of that legislature, that the line between the two states should be run and marked, according to its chartered direction. The duty of pursuing the direction is most explicitly enjoined on the commissioners, and zealously enforced by the terms of that act.

Virginia may be supposed in her act, to have displayed the same intention, and to have enjoined its effectuation upon her commissioners in a style not less explicit, and in terms not less urgent than those employed in the North Carolina act. Had the commissioners then, thus empowered and instructed by the legislative acts of their respective states, concurred in the performance of their duties, and run the line from the proper beginning point forty-five degrees south of west until it had struck the Tennessee river-- would the state of Te nnessee have urged its obligatory effect, and consented to abide by 1 t? It is believed not. Ur suppose the line to have been run by the nutual and concurrent agency of the commissioners of the two states in the direction of $45^{\circ}$ north of west, until it had reached the Ohio river.-- would sentucky have acknowledsed $1 \mathrm{ts}$ binding effect? And if she did not, would Tennessee have urged it upon her?--But suppose the comissioners to have 
united in the discharge of their duties under the laws investing them with their powers, and to habe begun by mistake at a point in a degree of north latitude, higner or lower than the chartered parallel, and to have run due west, the same or a less distance than Walker ran.would the line so run and marked have been binding on the states? If it would not in the case last put, it would not in the last or either of the former; still less can the erroneous line of walker be binding on the states. A line run and marked according to either of the cases put, would be inaffectual and unobligatory, on the grounds of mistake and error in the commissioners who had concurrently made it. The line run by walker must be aline inefiectual upon the same principle, and upon the additional ground that it was run without the concurrence of the North Carolina comissioners, not assented to, but reprobated by them; and upon the further ground, that it was never recognized by Virginia or Kentucky, North Carolina or Tennessee, nor affirned by them or eitier of them, as correct. It must be forgotien that the comissioners for the states of Virginia and North Carolina were not empowered by the acts of their respective states, to unite in running, marking and fixing the boundary line between thetwo states.

The boundary line had been fixed in the celenial charters and in the respective constitutions of the states. Taey were appointed to extend and mark, not a line, which they might fix upon, but the line which existed in a state of unerring fixture; for the duration of which, in its unerring and fixed position, the Heavens in which it was not less legible, than in the charters and constitutions aforesaid, stood pledged.

It is the privilege of sovereignty to denark its boundary on the Heavens, and it only reduses them to a visible and sensible position upon the surface of the earth in subservience to its purposes of detalied jurigdiction. A line marked, not ac ording to the known and setuled 
direction of the fixed line, had it been done by the concurrence of the commissioners of both states, would not have been binding on either, because the states had not intended to alter the boundary line, and had not delegated the power to alter it; and because the alteration, whether produced by ignorance or accident, was in transcension of the power and the instructions connected therowith, in the acts delegatins it. But the line marked by walker, so far as it relates ts the authority under which it was done, was a matter exclusively between lim and the state of Virginia, unobligatory upon North Carolina, for the want of concurcence and assent, and on account of her express dissent, and obligatory or not upon Virginia, as she might choose. It ran through her territory, was run by her own agent, and she had a right upon the most obvious princidies of proprietorship, to consider it in relation, as well to its origin as to its effect, in what light she choose. As proprietor and sovereign, she had an unquestionable risht to run and mark whatever lines she pleased upon her own territory.

The chartered line was the obligatory line upon the two states, and mast remain so until altered by their mutual consent. No consent of that nature is perceived in the line run by walker, whether reference is had to the facts and circumstances under which it was run and marked, or to the legislative acts of the two states, or of either of them in relation to the running or marking thereof. But if the line of Walker were to be considered as sbligatory, it could only be so considered (if it had every other obligatory requisite) on the ground that what was thesry had thereby become fact; that the ldeal line had thereby been made real and accessible to the senses of the comnunity. But that 1 ine, if we are to onfide in the paper purposting to be the report of $\mathrm{Walker}_{\mathrm{i}}$ and Smith in relation thereto, was not run, throughout from the point of beginning to the Tennessee river. From the clear Fork, to a point at, or near the mouth of Jby's river, a distance of 109 miles, was neither 
run nor marked by Walker; for that distance, and the distance between the Tennessee river and the ulssissippl river, there is not even the shadow of pretence for a departure from the chartered line. The legislative acts of the states of Virginia and North Carolina, upon which the Tennessee gentlemen rely, as having an affirming effect upon Walker's line, are principally those by which new counties at different time, posterior to the runnins of that line, were erected in, and by the states respectively. In those acts, the dividing line between the two states is eferred to by each, as the occasion sugsested, as some portion of the boundary of the county about to be erected, not by the name of Walker's line, or the line run by Walker, but as the boundary line between the two states, or as the North Carolina line or Virginia line, without any reference to the line NL 395,407 414,438 450,473 598,599 395,372 C. H. 589, 87,111 146,399 199,392 표. 276 run by Walker. Those acts are not thought to possess suficient relevency to the subject to entitle them to written comment, or discussion in this report or discussin in this report; but they are referred to in the margin hereof, cogether with all the legislative acts upon which the gentlemen gave verbal indications of reliance. The 411,445 466,365 letters C. H. point to the Chancellor's revisal of the Virginia laws. I to LiHell's volumes of the Kentucky laws, and $N_{\text {. }}-$ to Iredel's revisal of the North Carolina laws.

The act of the Virginia legislature concerning the southern boundary of that state, passed at the October session of that legislature in the year 1791, is spelcally exce,ted from the acts refered to in the margin, as entitled to consideration, because of its reference in terms to Walker's line. That act is in the words following, viz:- Whereas official infornation both buen received by the seneral assembly, that the legislature of the state of North Carolina have resolved to establish the line, commonly called Walier's line as the boundary between North Carolina and 
this commonwealth, and it is judged expedient to confirm and establish the sald line on the part of this gtate. Be it therefore enacted by the general assembly, That the line commonly called and known by the name of Walker's line, shall be, and the same is hereby declared to be the boundary line of this state, 2d. and be it further enacted, That in all the courts of equity and law within this commonwealth, the claims for lands lying between the line commonly called waliser's line, and the line commonly called Henderson's line, shall be decided in favor of the eldest title, whether derived from this comnonwealth, or from the state of North Carolina". Before any comnent be made upon this law it should be remarked, that the county of Rentucky hadbeen erected by the legislture of Virginia, embracing the territory now embraced within the state of Kentucky, that the legislature in the erection of that county, had called for the North Carolina line as its southern boundary; that af terwards when they erected the three counties of Fayette, Jefferson and Lincoln, out of that county, they called for the North Carolina line as the southern boundary of Lincoln, the most soutinerly of those three counties; and afterward in the year 1782, when those three counties were erected into the Kentucky district they were incorporated into that district by their existing boundaries; and that afterwards again in the year 1789, the same legislature by the enaction denominated the compact, under, and by virtue of which the district of Kentucky was erected into a state, stipulated for that event, recognizing the district, by its existing boundaries. viz; "Un tie south by the Carolina line". The conpact aforesaid was af terwards, viz; on the 4 th dajof February, 1791 , approved by the congress, with an expressionof their assent, that the said district might, pursuant thereto, go into a state and be admitted into the union according to its actual boundaries on the 18 th day of December 1789, as a new and entire member thereof, by the name and style of the state of Kentuciry; that the district of Kentucry did, on 
the 19th day of April 1792, by the formation and adoption of a constitution, in which was incorporated tre compact aforesaid, erect itself into a state, pursuant therto, and to the act of congress aforesaid. It should be further renarked bef sre any comment be made upon, or any exposition given of the Virginia act of 1791 above recited, that the state of North Carolina, in November 1789, did by solemn legislative act, cede to the United States all the right, title and claim, which she had to the sovereignty and territory of tre lands situate within her chartered limits west of a line on the extreme height of stone mountain at a place where the Virginia line intersects it. running thence, sc., and did thereby authorize he senators in congress from that state, to make a conveyance thereof to the United States of America; and that Samuel Johnston and Benjamin Hawkins senators in congress from that state, did by their deed of conveyance on the 20 th day of February 1790, convey to the United States the soil of North Carolina, according to the boundaries contained and recited in the act of that state above alluded to; and that the congress did by an act approved on the 2d day of April 1790, accept from the state of North Carolina by the deed of conveyance made by her senators as aforesaid, the territory and sovereignty of the western lands aforegald, within and according to the chartered limits of that state. From the foregoing facts must be evident, that in October 1791, neither Virginia nor North Carolina could exercise any jurisdiction in relation to the boundary line now in question. Virginia had preclud d herself by her compact with the district of Kentucky; and North Carolina had precluded herself by her surrender to the United states of the territory which is within the now state of Tennessee and of all pretension to sovereignty and Jurisdiction over it. Of this cession of soil and sovereignty made by the state of North Carolina to the United States in Novenber 1789, and of the acceptance thereof by the United States in April 1799, Virginia 
cannot be supposed to have been ignorant; nor can she be supposed to have been ignorant of her compact of cession to the district of sentucky made in 1789, and ratified by congress in February 1790: And knowing these facts she must have known in Jctober 1791 when she passed the act above united, that $\mathbb{W}_{2} 1 k e r^{\prime}$ s line so far as it passes through what is now the state of Sentucky, was alike without the reach of the jurisdiction of North carolina, and of her own, and shemust alike have known, and from the same source, that North Carolina had by her act of cession and conveyance to the United States, renounced all pretensions to walker's line, and ceded and convejed by the chartered line, she could not be unconscious, that she had by solemn compact, ratifled by congress, surrendered to the state of kentucky ffor it was then an inchoate state) all the territory North of the said chartered line, and by reference to it in that character, and that she was thereby estopped from legislating in relation to that boundary, or any other as s substitute for it, When the, it may be asked, did she pass the law? The facts defailed in Walker's report, taken into connection with the 2nd section of the law itself, and the other facts recited, furnish the answer. Walker and Ienderson had each run different lines for more than a hundred miles westward from the point of beginning, either of which lines, had it corresponded with the line of latitude, would at the time it was run, have been uncessarily binding upon their respective states, because it would have been a designation upon the surface of their chartered boundary. Those states after they had respectively made the cessions of territory and jurisdiction, the one lentucky, and the other to the United states, as above stated, would still have been bound by so much of its as remained their common boundary; but disagreeing as to the correctness of both lines, it was competent for them to unite in the substitution and establishment, of either for the line of latitude, so far as it could be thereby made (from their relative possession to 
each other.) a common boundary. To that extent only had they power to act upon it concursently. - Carolina could not act upon it, west of the line of cession to congress. But it was upon the receipt of afficial infornation, (as Virginia declares in the act) that the legislature of North Carolina had resolved to establish the line commonly called Walker's line as the boundary between North Carolina and herself; that she judzed it expedient to confirm and establish that line on her part; North Carolina could establish it west only to the eastern line of the territory, which she had ceded to the united States, and which is now the eastern boundary of the state of Tennessee. Virginia, by reason of the compact which she had made with Kentucky, could exercise no jurisdiction in relation to that line furtier west thou the eastern limits of Kentucky; she could by no concurrent act with the state of North Carolina, go farther west upon that line than what is now the eastern boundary of the state of Tennessee. It is but reasonbble, as that act purports a concurcence with the state of North Carolina, in relation to its object; viz; Walker's line, to confine its effect to so much only of that line as North Carolina could concurrently with Virginia, act upon. How far the line run commenced east of the eastern limits of what is now the stace of Tennessee, we are not informed, nor have we any immediate means of certain information; but we are bound to suppose from the above recited act, that the line of $\mathrm{w}_{\mathrm{a}}$ liker was to some considerable extent, in the autumn of the yearl791 contemplated by the two states as their common boundary. The provision in the $2 d$ section of that act that the lands lying between that line and the line run by Henderson, shall be decided to belong to the persons holding the elder grants therfor, is strongly corroborative of this construction. From the report of Walker we learn that Henderson ran from the poin of beginning as far west as the Cumberland mountain; from that point eastward Virginia had the power to confirm that line, because it was east of the territory 
ceded by compact as af oresaid to sentucky. The reference in the aforesaid second section of the act to Henderson's line, shows tilat not only the legislature in the enaction of the law intended to confine and limit its effects to so much of Walker's line as was within the jurisdiction of Virginia, but to that jart of it which was in relation to that object, within the concurrent jurisdiction of virginia and North Carolina. But the act aforesaid could not be obligatory upon North Carolina without her assent, and she could not jield her assent beyond the limitg of her jurisdiction; that limit on the west was the extreme height of stone mountain. But there is no evidence tiat she ever did assent.

The act aforesaid is predicated upon her promise to assent; if that assent was with held or refused, there is no doubt that tine act aforesaid would not be obligatory upon Virginia; and that the chartered boundary would not be thereby altered as between even those states.-It can not amount (without the consent of North Carolina) to a cession by Virginia to her of all the territory and sovereignty between Walker's line and her northern boundary; still less would it, predicated as it was upon the promise of North Carolina to conflrm Walker's line, vacate the compact with Kentucky, and transfer to the United s tates the territory and sovereignty west to the Tennessee river, between that line and the line of latitude north $36^{\circ} 30^{\prime}$ and that too without the assent either of the United States or North Carolina. The law therefore, it is repeated, can have no obligatory effect upon sentucky, and none upon Virginia in re lation to any portion of that line, that was not at the time of its enaction, a common boundary between Virginia and North Carolina, But as a conclusive proof that the law aforesaid, neither had, nor was intended to have, an effect upon that line west of the western linits of North Carolina, The state of Tennesseee in the month of Februray 1796, when she formed her constitution, ordained in the $32 d$ article 
of the bill of rights, in that constitution, by express recital of her limits therein, that her northern boundary was as discribed in the act of cession of North Carolina to the United States, which has been shown to be the latitude of $36^{\circ} 30^{\prime}$ north. The words of that article, so far as thej relate to this subject, are as follows, viz:"That the limits and boundaries of this state be ascertained, it is declared that they are as hereafter mentioned, that is to say: Beginning on the extreme height of $\mathrm{S}$ tone mountain, at a place where the Virginia line intersects 1 , inlatitude $30^{\circ} 30^{\prime}$ north running thence, scdccc thence along the main edge of sald mountain to the southern boundary of this state as described in the act of cession of North Carolina to the united States of America; and all the territory, lands and waters, lying west of the said line as before mentioned, and contained within the chartered limits of the state of North Carolina, are within the bound arjes and limits of this state, over which the people have the right of exclusive sovereignty and soil. Bc" What is now the state of Tennessee existed, when the Virginia law af oresaid was enacted, in the altitude of a territorial zovernment, bounded on the north by tine line of latitude aforesaid: $S$ he was not in that altitude, or any other, as it has been shown she could not be, either noticed in, or affected by thatlaw. wore than five years afterwards, when she passed from the territorial to a state government, she not only did not assent to the alledged effect of that law upon her northern boundary; but most solemnly renounced 1 and adhered to the chartered boundary of North Carolina as her northern boundary. The allegation that $W_{a}$ liker's had been acquienced in and affirmed by the states of North Carolina and Virginia, in and by their various legislature acts, above refered to in the margin of this report, is abundantly peputed by all in their solemn acts in relation to that boundary, from the time that line was run and marked and not less by the Virginia act of 1791 above recited, which was her last, upon that subject, thou by her act erecting sentucky into a district, and her act of 
compact with that district. Why, if she had affirmed Walker's line previously to the passage of that act, should she then think it expedient to confirm it, and then enact its confirmation? and why, if North Carolina had previously affirmed it did she then(as the act recetes she did) officially inform Virginia, that she would confirm it? and why, if she had confirmed it previously to her act of cession to the United $S$ tates did she in that act cede according, not to that, but her chartered line? and why, if Walker's line had ever been confirued by the state of North Carolina and Virginia, did the state of Tennessee reject it in her constitution, and recognize as her only legitimate northernboundary, the line of latitude according to the charter of North Carolina? and why have the states of Tennessee and Kentucky, if Walker's line had been their legitimate dividing boundary cautiously avoided in all their enactments in relation thereto, its recognition in that character? and $w$ have they refered uniformly to the chartered line as their common boundary? And quere--can the state of Tennessee lawfully exert jurisdiction north of the line established in her constitution as the boundary the of? And to what jurisdiction would a felony, comritted between walker's line and the line of latitude attach? It should still be remembered that all the legislative acts, to which reference is made in the margin, (herein above) as those relied upon by the commissioners from Tennessee, to evence the confirmation of Walker's line, were passed anterior to the passage of the act of compact by the state of Virginia, above referred to, and the act of Jctober, 1/91, above recited, and to the act of cession by North Carolina, and of course to the formation of its constitution by the state of Tennessee. And as further evidence that Walker's line had not been affirmed by any of those legislative acts, to which reference is made in the margin, the following resolutions adopted by the legislature of Virginia, at the November session of $1 / 89$, may be referred to with 
much confidence, viz:"Resolved, That the Executive be requested to report to the state of North Carolina, the great anxiety of this commonwealth for the establishment of a boundary line between them; to propuse the establishment of the line commonly called walker's line, and to report to the general assembly at their next session, the answer that may be recelved. "Resolved, That if the proposal for the establishment of Walker's line be accepted, the Executive be empowered to execute a deed confirming the same, upon recelving a lise deed from the state of North Carolina. "Resolved, That if the said proposal be not accepted, the Executive be empowered to appoint any number of commissioners, not exceeding three, to meet any other commissioners who may be appointed on the sut of North Carolina to confer on the propriety of establishing Walker's on Henderson's 1in, and to report to the legislature of each state their proceedings in the premises."

The resolutions not only indicate that Walker's line had not been estabilished, but that Virginia had nade unavailing efiorts with North Carolina to establish that or some other visible boundary between the two states. The resolutions authroize the Executive to report to that state, the anxiety which was felt on that subject. These resolution if other evidence were wanting, would be sufficient to prove, that Walker's line had not, anterior to hovember, 1789, been established; and it has been shown, that after that period, there existed no power in those two states to establish it further than it was or might be made their common boundary. Being convinced, thefefore by the foregoing and other views, of which the subject is susceptible, (but for which there is neitiner time nor room here, ) that the line commonly called Walker's line, never was confirmed by either the state of Virginia or of North Carolina, anterior to the 13 th day of December, 1/91; and that it was then confirmed as far west only from the point at which it 
was commenced, as the western boundary of North Carolina which was the extreme height of stone mountain, and the utmost extent to which those states possessed at that time, the power concurrently to confirm it; and of course, that it had not as to the balance of its extent westward any more binding effect upon either the state of sentucky or of Tennessee thou at our other line run and marked through that region of country by the savages of its forest, or the citizen hunter of any of the states pp 33.

I, Rowan could not find, in all that was alledged on the part of Tennessee, in relation to the confirmation and obligatory effect of Walker's line, an apology for a doubt as to the legitimate boundary line between the two states. That the line of latitude $30^{\circ} 30^{\prime}$ north, was, and is the true legitinate, and only obligatory boundary line between the two states, he had the most thorough conviction. When, therefore the firgt note was received from the Tennessee comalssioners, he could not find, in any doubt (for he had not) which he entertained in relation to the right of his state to the territory and sovereignty between Walker's line and the line of latitude, a native to surrender to the state of Tennessee that territory and sovereignty, or any part thereof. It was, in his most delibera e opinion, not less clearly the property of this state, than any portion of the interior thereof.-even that embracing its Capital. That the state of Tennessee had usurped the possession and jurisdiction of that territory, formed with him no native to surrender it to her without an equivalent; and he culd not se in her declaration made in that note, that she would forbear to extend her usurption to our territory and jurisdiction west of the Tennessee river, an equivalent for the surrender of what she had usurped east of that river; and he could construe that note into nothing more nor less, than such a promise of forbearance on the part of the stateof Tennessee. To this interpretation of that note, he was led, not only 
by the import of its words, but by the information received from the Tennessee commissioners, that the legislative of that state, had, at their last se ssion, passed an act directing the surveyors tnereof, upon the fallure of this negociation,immediately to ocupy and survey all the land west of the Tennessee river, between the line run by Alexander and walker's line extneded from the Tennessee to the Hississippi river. The circumstance too, that note, although their first, should have been declared ( as it was verbally), to contain their ultimation, their sive qua now, was not in his mind of a concllator nature. That the state of Tennessee, after having in violation of her own constitutuon, and of the just and constitutional right of the state of Kentucky, usurped near two milion acres of the land of the latter, should propose a compromise and offer as the only terms of that compromise, at the very threshold, and in the shape of a sive qua now, that she would forbear to usurp another million of acres, as the only equivalent for the million she had already usurped, was not, in his opinion, very flollering (to speak the best of it) to tire just pride of this state. He was constrained to suppose that the proposition was predicated upon the belief, that the state of Kentucky locked either the wisdom to discern, or the firmness to asset her just right; and, therefore, he could not ac ede to it. Argument drawn from the proximity of the two states, and the necessity of their confraternal intercourse to their mutual comfort and interests, were not without weight to which they were entitled, in the consideration, by him, of this matter; and he was prepared to be influenced by them, so far as their influence might be reciprocated-and furtier, he could not be, consistently with that respect which he entertains and is proud to cherish, for his state. That the state of ientucky should cultivate/ with the state of Tennessee and her other sister states of the Union, from the sarae motives that they should cultivate amity with her, he is prompt to acknowledge; but that she can have any motive that 
that is not common to the proudest of them, he denies unhesitatingly. The argument that the assertion of its right by sentucky, to the territory north of the line of latitude, would eventuate in the disruption from the state of Tennessee of a large mass of its people, and the location of them within the Jurisdiction and under the laws of the forier, from which they are in all their sentinents and habits abhorant was, though not of a flatering character, not with out its weight with him; for though he cannot think that the government and laws of sentucky are less friendly to civil liberty and to all the tenurs which connect themselves with the human heart, thou those of the state of Tennessee; yet, he regards with great indulgence even prejudices of that sort; and he was willing and proposed to take in exchange for that mass of pop= ulation and the territory to which it was fastened, and equivalent in the Wilderness, west of the Tennessee river and south of Alexander's line, according to the enterior elther of quantity or value. Indeed, he even consented (reluctontly he acknowledges) and proposed to leave to the state of Tennessee, the territory and jurisdiction south of Walker's line, from the Tennessee river east to Jby's river, upon the condition, that here should be no obstruction on the part of the state of Tennessee, to the exercise of its jurisdiction by sentucxy, to the line of latitude along the balance of its southern boundary. This proposition was not approved of entirely by his judgment; but he was extreme ly unwilling to be thought to possess none of that spirit of concillation which seemed to influence his colleague to concede all; besides, he was encouraged to go thus for by the consideration, that the legislature of his state had displayed the game temper, in one of 1 ts enactments upon this subject a a former session, and by this other consating reflection, that the legislature had, in the law investing him with the authority unler which he acted, reserved to itself the power of affirming or disafirming his acts. He was disposed to go as far in 
displaying the zeal of his state to cultivate amiciable relations with the state of Tennessee, as that zeal could in his opinion be displayed, compatibly with its honor, for he holds it to be a truigm in politics, that the amity of that state or nation that does not respect itself, is not worth cultivating. If the state of Tennessee would come out and Prankly acknowledge our rights and renounce her wrongs in relation to them, and appeal to the senerosity of sentucky for the land in question, he feels a pride in believing, that his state would evince upon such an appeal, that her disposition to be liberal, was not less than her capacitj to discern and vincicate her rights, when they were attempted to be obtained from her, either by force or address. But he could not believe, that he had been appointed to give for the state of rentucky to the state of Tennessee, a slip of territory lying alons its southern boundary, large enough for some three, four or five counties; and if he could have so though, he would not have agreed, that the generosity displayed in the gift, should have been obscured by its exaction on the part of the donee through the medium of a compronise. The argument that though our right is clear, we have no remedy; that the Congress have refused to erect a tribunal to investigate and decide it; and that therefore we ought to give it up, had no influence upon him. He has a confidence that the national government, when it sees that this matter cannot be settled upon any equitable terms, will furnish the competent tribunal for the porific and energetic enforcement of the rights of sentucky; but if this tribunal should not be furnished, it will never be to late for Sentucky to surrender her rights. The present occasion did not, in its manner, seem to him to invite to haste in making the surrender. It can be done, it is believed, at least as gracefully at any future period and under any other circumstances as present. But it is said, we are about to lay off and bring into market our western lands and that the 
state of Tennegsee, unless we agree to this sive qua non proposition; will taire all of our lands that lie west of the Tennessee river, betwe an extension of Walker's line and the line run by Alexander. That alone if there were no other objection to the proposition, would compell him to disagree to it. He could draw no motive from the late act of the Tennessee legislature, providing for the selzure and appropiation of our territory in that quarter, to accede to the propositions of her comissioners. While he considered that act as brandishing the threats of that state, he considered it also as a proclamation of its impatency to inforce it; but a state cannot be influenced by such notives-- she must dare to use her rights to their just extent-- she cannot purchase the privelese of exercising her legitimate rights; the cannot be supposed to depend upon any extraneous matter-- they are inherent and must be . exercised according to her will; they cannot depend upon the will of the state of Tennesgee. The shadowy pretext of Walker's line cannot, by the utmost hordihood of conjecture, be made to apply to our territory west of the river Tennessee. That line was neither run or marked, nor authorized to be run west of that river. The circumstance that Walker marked reees on the west bank of the river Mississippi, for an abbttal to the line run by him, is (whether the fact be according to their allegation of it, or not) too obviously ircelevent and immaterial for either comnent here, or consideration by the legislature. He regrets, that a fact so utterly indifferent to, and foreisn from the merits of the subject should have been attempted to be connected with it, in its submission to the consideration of his state; he regrets it, because its effect would seem o have been inferred by those who urged it, rather fron what they supposed to be the timidity and weakness, than the discemment and intelligence of the state of sentucky, The sentiment that our claim, if not barfed by lap of time, is, to speak the best of it, state and antequated, would seem to be predicated upon the same unflattering hypothesis. 
Nentucky is to intelligent toot to know, that her forbearance (during the period in which she has been anxiously, but unavailing endeavoring to obtain an amicable acknowledgement of her rishts) cannot be cunstrued into an abandonment or dereliction by her, of those rights; nor can she feel herself plattered by this, or any other argument predicated so monifestly upon her ignorance of the attributes of her own sovereign character. That lapse of time, can neither abate nor bar the right or claim of a sovereign, is a principle without which sovereign states could not exist, even in contemplation; and one which has a place so conspicuous in the very alphabet of polltics, that everbody is supposed to know and understand it. He begs leave further to state, that he endeavoured most scrupulanty throughout this business to ascertain and conform to the will of his state. And he felt himself admonished by the varlous legislative acts upon this subject, and more particularty by the report made thereon, during the present session, by the committee for courts of justice, to adhere most pertinaciously in any adjustment which might be made, to the rights of his state, in relation as well to the territory, \&s to the sovereignty thereof. Upon the strong view tairen in that report, by the most distinguished law characters in the legislature of this country, he could not but place much reliance. Its tenor and lmpart evinced forcibly, not only the right of the state, to the territory and jurisdiction in question, but indicated most distinctly its determination not to abandon but to asgert perseveringly that right. Indeed the consideration that the repart was convicted with, and made the basis of the law investing him with authority to act in this natter, constrained him to regard it with special heed.

He subjoins a copy of the report of $W_{a}$ lker and Sinith herein before referred to, with either admitting or denying its authority; and he annexes hereto, the correspondence between the commissioners in the order in which it took place; he will nake no comment upon it. It will be 
readily perceived, that the agreement of his colleague to the first and anly written propositions of the Tennessee commissioners determined them to make the appeal indicated in their last note, and that he, in the intermediate correspondence, occupied to speak the least of it a delicate and embarrasing posture. By the protraction of the correspondence however, the legislature are enabled to discover, that the commissioners from Tennessee (in the event of the fallure of their proposition with the legislature ) are empowered, and as it nay inferred, disposed to submit the matter in dispute between the two states to arbitration. It cannot escape observation, that Walker's line in their propositions, is defined a line understood and acted upon by the two states, to be the line between them, east of the Tennessee river, fe., This it is hoped has be n shown not to be the Pact; for all the counties erected by the state of sentucay upon her southern barder, as well as those erected by Virginia in the same region, are bounded by the line of latitude, and not by $W_{3} l k e r ' s$ line.

He trusts that the legislature of his country for whose goodness in the unsolicited appointment of him to this task, he feels, and shall always cherish, the most profound gratitude, will have the charity to belleve (what he avers to be the fact) that he was situated throughout this negotiation, not less by a strong solicitude to settle the unhappy difference between the two states in relation to their common bouniary, than by an earnest zeal to maintain the honor and just rights of his state in any adjustment that night be nade thereof. He regrets that his efforts have been unavailing, and will be happy to see an adjustment of it upon principles of reciprocal justice. He cannot think that principles of charity can have any application to sovereign states in relation to each other, and therefore could find no motive drawn from that source togive to the state of Tennessee, territory to the value of at least three mililions of dollars, togetier with the jurisdiction over it. lie 
would rather if it is to be given, have agreed to give it to the poor of his own state, or to denote it to the education of their childred, or to any other of the many useful purposes, to which it misht be applied by his state.

He begs specially, hat his report may be considered as a hasty and humble attempt to indicate his views, rendered as he thinks necessary from the unpleasant circumstance of their being different from those of his worthy colleague; and he protests most emphatically against any inferrence from it or any part of it, injurious to his colleague, whose views and motives, he takes pleasure in believing, were not less honest than his own. He offers as an apology for the many defects of this report the haste under which it has been nade out; and begs that this apolosy may be applied also, to the correspondence on the side of the Mentucky commissioners, for during that correspondence, they were led to believe by the repeated declarations of the commissioners on the part of Tennessee, that one of then was c nstrained to set out for his stant on the lith instant at forthest.

I. Rowan begs leave in conclusion, to present to the legislature, the homage of his gratitude and reverence, and to subscribe himself most respectfully, their obe't serv't.

January $18 \operatorname{th} 1820$. John Rowan

ry. Sen. Jour. \& H. Jour. 1819-1820

$$
\text { A pendix } 44
$$

Report of the Acting Governor to the House of Representatives, on the boundary subject.

Gentlemen of the House of Re presentatives,

The commissioners appointed on the part of this state to confer with the comnissioners from Tennessee on the subject of the boundary line between the two states, nave transmitted to me their separate reports, together with the correspondence had in relation to tnat subject; which 
are herewith laid before you. Also a letter from the commissioners on the part of the state of Tennessee, adressed to me and which they desired should eccompany said reports. The length of the reports preclude the possibility of having them copied in a reasonable time for the other branch of the legislature. It is therefore hoped, that the houge of pepresentatives w111 lose no time in laying them before the other branch, so soon as the occasion may render it proper to do so. Gabl. Slaughter

January 18 th 1820.

Feb. 2.

To the honorable, the Gen. Assembly of the commonwealth of Ay. The undersis ed have the honor to report, that they have, with the Tennessee commissioners, agreed upon and executed certain articles of compact and settlement in relation to the line of boundary and separation between the states of Kentucky and Tennessee; which articles are herewith communicated to the house of representatives, and a copy thereof to the senate.

$$
\begin{aligned}
& \text { We have the honor to be } \\
& \text { With profound respect } \\
& \text { Lour obedient servants. } \\
& \text { John J. Chittenden } \\
& \text { Robt. Timble }
\end{aligned}
$$

Sen Journal

1820.pp 230

Resolution No 5

Resolution giving the consent of Congress to a compact concluded between the States of Kentucky and Tennessee, for the settlement of their boundary Line.--- Approved May 12

Resolved by the senate and louse of Representatives of the United States of America, in Conjress assembled, That the consent of congress 
be, and the same is hereby given to a compact or agreement made and concluded, by and between the states of sentucky and $\mathrm{T}_{\mathbf{e}} \mathrm{nnessee,}$ at Frankfort, in Aentucky, on the second day of February, on thousand eight hundred and twenty, to adjust and establish the boundary line between them and for other purposes. Land Laws Tennessee pp 646.

An act to ratify and confirm the adjustment of the boundary line between this State and the State of Tennessee, according to the articles of stipulation entered into by the Conmissioners appointed by both States, Approved, February 111820.

188 Whereas, Commissioners appointed by the State of Tennessee, with full powers to settle and adjust the boundary line between said state and this Comonwealth, have enterred into an agreement with commissioners appointed on the part of this state to confer with said cominisioners appointed by the State of Tennessee, which agreement, reduced to writing, bearing date the second day of February, one thousand eight hundred and twenty, and signed with the names and under the seals of the commissioners of both states, in the words and figures following, to w1t:

The States of lentucky and Tennessee, desirous of terminating the controversy which has no long subsisted between said states in relation to their comnon boundary, and of restoring the most perfect good understanding and harmony between them, have, for that purpose, appoint ed their respective comissioners, that is to say; The state of Kentucky on her part has appointed John J. Crittenden and Robert Trimble, and the

state of Tennessee on her part has appointed Felix Grundy and William - Brown, who, after a reciprocal communication of their respective powers, have agreed upon the following articles and stipulations: 
Article 1

189 The line of boundary and separation between the States of Lentucky and Tennessee shall be as follows, towlt: The line run by the virginia comisisioners in the year seventeen hundred and seventy-nine and seventeen hundred and eighty, commonly called Walker's line as the same is reputed, understood and acted upon by the said States, their respective officers and citizens, from the southeastern corner of Sentucky to the Tennessee river; thence with and up sald river to the point where the line of Alexander and Lunsell, run by them in the last year under the authority of an act of the wegislature of ientucky, entitled," An act to run the boundary line between this state and the State of Tennessee, west of the Tennessee river, approved February 8 1819." would cross sald river, and thence with the sald line of Alexander and Lunsell to the termination thereof on the Mississippi river below New Madrid.

$$
\text { Article } 2
$$

190 It is agreed and undergtood that from a point where Walker's line strikes the Tennessee river to the point where the line of Alexander and Lunsell would cross the same, the sald Tennessee river shall be common boundary of said states, and subject to their common use and concurrent jurisdiction. Any island or islands in that part of the river Tennessee which forms the common boundary between the two states shall be within the exclusive Jurisdiction of Kentucky; but any appropriations thereof by individuals, heretofore made under the laws of North Carolina or Tennessee, shall be valid.

$$
\text { Article } 3
$$

191 When ever the Governor of either state shall deem it expedient to have the boundary between the two states which is east of the Tennessee river, or any part thereof, run and plainly marked, he shall cause a notification thereof to be comnunicated to the Governor of the other 
State; and there upon, with all convenient dispatch, two surveyors shall be appointed for the purpose, one by the Governor of each state; and the surveyors so apjointed shall have power to employ a conpetent number of chain-cariers, and assistants, and they shall ascertain, surv ey and mark said line plainly and durably, having due respect to the provisions of the first article hereof; and it shall be the duty of said surveyors to make out and sign duplicate plats and reports of their surverys and proceedings, to be communicated by eachlsurveyor to the Governor of his respective state, to be deposited and preserved in the office of the secretary of state, for a testimony and memorial of the boundary between said states. And all cost and expense that nay be incurred under the provisions of this article, and in surveying and marking said boundary line, shall be paid by said states jointly and equally. Article 4

192 The claims to lands lying west of the $\mathrm{T}_{e}$ nnessee river, and north of Alexander's and Hunsell's line derived from North Carolina or Tennessee,shall be considered null and vold; and claims to Lands lying south of said line and west of Tennessee river, derived from Virginia or Lentucky, shalli in like nanner be considered null and void.

$$
\text { Article } 5
$$

193 All lands now vacant and unaporopriated by any person or persons claiming to hold under the states of North Carolina or Tennessee east of the Tennessee river and north of the paraliel of latitude $36030^{\prime}$ north, shall be the property of and subject to the disposition of the State of rentucky, which state may make a 11 laws necessary and proper for disposing of and grantins said lands, or any part thereof, and may by her self or officers, do any acts necessary and proper for carrying the foregoing provisions of thisarticle into effect; and any grant o. grants she may maze therefor, or any part thereof, shall be received in evide nce in all the courts of law and equity in the state of 
Tennessee, and be available to the party derivins title under the same; and the land referred to in this article shall not be subject to taxation by the state of Tennessee for five jears, except so for as the same nay, in the meantime, be appropriated by individuals.

\section{Article 6}

194 Claims to lands east of the Tennessee river, between Walker's line and the latitude of $36^{\circ} 30^{\prime}$ north, derived from the state of Virginia in consideration of nilitary services, shall not be prejudiced in any respect by the establishnent of Walker's line; but such claims shall be considered as rig.tfully entered or granted and the claimants may enter upon said lands or assent their rights in the courts of justice without prejudice by lapse of time, or from any statute of limitations for any period to the settlenent of the boundary between the two states; saving however, to the holders and occupants of conflicting clains, if any there be, the right of showing such entries or grants to be invalid and of no effect, or that they have parament or superior titles to the land covered by such Virginia claims.

\section{Article 7}

195 All private rights and interests of lands between Walker's line, from the Cumberland river, near the mouth of obey's river to the southeastern corner of Lentucky, at the point where the boundary line between Virginia and Nentucky intersects Walker's line on the Cumberland wountain and the parallel $30^{\circ} 30^{\prime}$ north latitude, hereto fore derived from Virginia North Carolina, sentucky or Tennessee, shall be considered as rightfully eminating from either of those states; and the states of kentucky and Tennessee reserve to themselves, respectively, the power of carrying into grant claims nut jet perfected; and in case of conflicting claims, if any there be, the validity of each claim shall be tested by the laws of the state from which it eminated, and the contest shall be decided as if each state, respectively, had possessed the jurisdiction and soil, 
and full power and right to authroize the location, survey, or grant according to her own rules, and regulations.

$$
\text { Article } 8
$$

196 It is agreed that the foregoing articles shall receive the most liberal construction for the effecting the objects contemplated; and should any disagreement arise as to the interpretation, or in the execution thereof, two citizens of the united states, but residents of neither sentucky nor Tennessee, shall be selected, one by the executive of each state, with power $t$, choose an unpire in case of disagreement, whose decisions shall be final on all points to them submitted.

$$
\text { Article } 9
$$

197. Should any further legislative acts be requisite to effectuate the foregoing articles and stipulations, the faith of the two states is hereby pledged that they will unite in maxing such provisions, and respectively pass such laws as nay be necessary to carry the same into full and complete effect.

\section{Article 10}

198 The foreguing articles and stipulations, if ratified by the Legislature of sentucisy during their present session, shall forever be obligatory and binding on both states, and tare effect from this day.

In faith whereof, we, the respective commissioners, have sioned these articles, and hereunto fixed our seals.

Done in duplicate at Frankfort, the second day of February, one thousand and eight hundred and twenty.

$\begin{array}{ll}\text { John J. Crittenden (Seal) } \\ \text { Robert Trimble } & \text { (Seal) } \\ \text { Felix Grundy } & \text { (Seal) } \\ \text { William Brown } & \text { (Seal) }\end{array}$

Carroll's Statutes pp 249

Revised Statutes of sentucky 152 
We the undersigned William Steele and Absalom Looney being appointed by the stete of rentucky and Tennessee, to run and mark the boundary line between the said atates, from the south eastern boundary of the state of Kentucky, at Cumberland mountain, to the Cumberland river near the mouth of obed's river, agreeable to the articles of treaty between the two states, William Steele on the part of sentucizy, and Absolom wooney on the part of Tennessee, and in pursuance of said appointments, have proceeded to run and mark said boundary, as follows: Beginning at seven pines and two black oaks on the top of cumberland Sountain, on the Tennessee line, where it crosses sald mountain, one mile and a half and twelves poles southwardly of the cumberland Gap: thence with Walker's old marked line south 86 West, by the nagmetic meridian, crossing the left hand fork of lellow creek at one mile, crossing ingo wountain, and then crossing Bennett's Fork of Yellow creek at five miles; then LOB Hountain, crossing Bowman's Fork of the Clear Fork of Cumberland at nine miles; the Trace Fork at twelve miles; Buffalo a t fifteen; the Laurel Fork at eighteen miles; Tom's creek at nineteen miles; and relmary at twenty-one miles; then crossing rine Mountain, and the clear Fork of Cumberland river, in the wot at twenty five miles; then crossing the Hackle snob to the Elk Fork at twerity-eight miles; Indian creek at twenty-nine miles; then Gellico sountain and Gililico creek at thirty-three miles; and the risht hand fork of Gillico at thirty-six miles; Rock creek at forty-one miles; Marsh creek at forty-geven miles; the Roaring ponch at forty-nine miles; Bear creek at fifty-four miles; the Big South Fork of Cumberland at fifty-eight miles; Rock creek at sixty-eight miles; the left hand fork of the Little South Fork at seventy-six miles; passing the Cnimmey or rilot Rock at seventy-eight miles; Crossing the ropular Wountain into stockton's Valley at eighty-seven miles; and rike's turnpike road at ninty miles; then crossing wolf river at six miles; 
then Sulphur wick creek at one hundred and four miles; Nettle creek at one hundred and twelve miles; in all one hundred and fourteen miles to three Hackberry trees on the bank of Cumberland river, oppoilte the point where Walker's old line strikes the west bank of Cumberland river, opposite the point where Walker's old line strikes the west bank of Cumberland river, and about twenty-iour poles above the house occupied by John Kerr in 1821; thence west wlth Walker's old line to the Tennessee river and up sald river to the point where the line run by Alexander and unsell, in 1819, strikes said river; the river being the cominon boundary between the two states, and subject to their common use and concurcent jurigdiction; and thence with the line run by Alexander and Munsell, on the parallel of $36^{\circ} 30^{\prime}$ to the middie of the channel of the Hississippi river, oipposite the point on the Mississipji below New Madrid, fixed marized, and ascertained by them as the point of intersection of said parallel and sald river

John Nerr's house. Began on the twenty-first day of May, and ended on the ninth day of July 1821. Done in duplicate this 9 th day of July 1821, on the line near ubed's river

Wm. Steele Survejor, sentuciky. A. Looney ", Tennessee

58 Berry seauy William Steele, Jr. Assistant.

50 Samuel Lone

52 Daniel G. Miller

$47 \mathrm{Wm}$. Johnson

… Chain Carrier \& markers,

47 George Argenbright

47 Richard steele.

Sugsis tance

Pack horses etc. 239.

Total 597.00

The amount as stated was paid by William S teele, on the part of sentucky and Absolom Looney, on the part of Tenness, Each an equal part. sen. Jour. pp 24-- 1821 
1821 Acts Tennessee chapter 44.

An Act to establish the boundary line between the states of Tennessee and Nentucky. - Novenber 13.

Section 1. Be it enacted, etc; That the line lately run between the States of Tennessee and Lentucky, by William Steel and Absolom Loony so far as it extends, shall be confirmed and established as the boundary line between the said states, in conformity with the report of the sald Wllliam Steel and Absolom Loony, which is as follows, (viz)

\section{Substitute John Reaves for Lerr}

II

20 poles for 24 poles

Sec. 2. That this act shall go into complete operation so soon as the Legislature of rentucry sh all pass a law ratifying and confirming said report of the sald William steel and Absolom Looney. sy. Acts. 1821 Nov 22. Chap. 206. pp 206 An act to establish the Line lately run between the state of Tennessee and key.

Be it enacted by the General Assembly of the Commonwealth of sentucky, That the line, as run and nariked, in the year 1821, by William Steele, the survey or on the part of sentucky, and Absolom Looney, the surveyor on the part of the state of Tennessee, in pursuance of the authority of their respective states, be, and the same is hereby ratifled and declared to be the boundary line between the said states;

$$
\text { See App. }-45-- \text { PP. } 136
$$

Steele \& Looney.

Ran line from the seven pines\& two black oaks southeastern corner of 4y. to first crossing Cumberland river going west. Started on Cumberland At. $36^{\circ} 34^{\prime} 53^{\prime} .5$ more than $5 \frac{1}{2}$ iniles north of latitude line.

They. made it $114-1$. Walker " " " $1199 \frac{1}{2} \& 1243 \mathrm{ft}$. 
1821 April 29

Wm. Steel for Ky., and Absolom Looney for Tenn., run and mark the boundary line between the two states from the southeast corner of the state Westward 114 miles to the Cumberland river, near the mouth of Obey's river. Colling Vol 1-29.

And whereas, This Commonwealth does approve and is willing to ratify and confirm each and every article and stipulation of the said agreement; therefore,

Be it enacted by the General Assembly of the Commonwealth of ientucky That the boundary line between the state of Tennessee and this comionwealth, as described in said agreement, subject to be run and mariked as therein provided, shall be, and the same is hereby, ratified and confirmed.

Be it further enacted, That each and every article and stipulation of said agreement, either relating to the boundary line between the said States, or to the land claims of individuals, or to vacant and unappropia ted lands, or to any other subject-matter in said agreement contained, snall be, and the same are hereby, ratifled and confirmed, and shall be regarded in all courts of justice in this comonwealth as the law of the land.

The boundary of the state of Kentucky is declared to be as follows: Beginning at seven pines and two black oaks on the top of cumberland Lountain, on the Tennessee line where it crosses said mountain, one mile and a half and twelve poles southwardy of the Cumberland Gap ; thence with Walker's old marked line South 86 west, by the magnetic meridian, crossing the left hand fork of lellow creek at one mile, crossing wingo dountain, and then crossing Bennett's Fork of Yellow creek at five miles; then Log Mountain, crossing Bowman's Fork of the Clear Fork of Cumberland at nine miles; the Tract Fork at twelve miles; 
Buffalo at fifteen; the waurel Fork at eighteen miles; Tom's Creek at nineteen miles; and rrimray at twenty-one miles; then crossing Pine Mountain, and the Clear Fork of Cumberland river, in the wot at twenty five miles; then crosing the Hackle wnob to the Elk Fork at twenty-eight miles; Indian creek at twenty-nine miles; then Gellico Mountain and Gillico at thirty-six miles; Rock Creek at forty-one miles; Warsh creek at forty-seven miles; the Roaring Ponch at forty-nine miles; Bear creek at fifty-hour miles; the Big South Fork of Cumberland at fifty-eight miles; Rock creek at sixty-eight miles; the left hand fork of the wittle south Fork at seventy-six miles; passing the Chinmey or Pilot Rock at seventy-eight miles; Crossing the roplar Mountain into stockton's Valley at elghty-seven miles; and Pike's turnpike road at ninty miles then crossing wolf river at six miles; then Sulphur Hick creek at one hundred and four miles; kettle creek at one hund ed and twelve miles; in all one hundred and fourteen miles to three liackberry trees on the bank of cumberland river, opposite the point where Walker's old line strikes the west bank of Cumberland river, and about twenty-four poles above the house occupied by John Kerr in 1821; thence west with Walker's old line to the Tennessee river and up said river to the point where the line run by Alexander and Aunse11, in 1819, strikes said river; the river beins the common boundary between the two states, and subject to their common use and concurrent jurisdiction; and tience with the line run by slexander and Aunsell, on the parallel of $36^{\circ} 30^{\prime}$ to the middle of the channel of the Mississippi river, opposite the point on the Mississippi below New Madrid, fixed, marked, and ascertained by them as the point of intersection of said parallel and said river; thence up said river to the mouth of the Jilo river, including within the boundary of Kentuciry the islands in sald Missisgippi river known by the numbers, One, Two, Three, Five (or Wolf Island), and Eight; thence crossing the Ohio 
river to the Northwest bank, at low water mark; thence up the northwestern bank of said river, at low water mark, to a point opposite the mouth of the Big andy; thence across the Uhio river, and up the sald Sandy river to the mouth of the main western branch of Sandy; thence up the northeastwardly branch to a point on said branch from which a line drawn south 450 west will strike the road over the Gumberland Wountains at Little Polnt Gap, by some called the Hollow Mountain, where it terminates at the west fork of Sandy, commonly called Russell's fork; and thence, continuing on the top or highest point of sald mountain, keeping between the headwaters of the rentucky and Cumberland rivers on the right, and the headwaters of Powell's and Nuests' rivers on the left, to the besinning on the sald Gumberiand Mountain.

The sovereign power and jurisdiction of the Comnonwealth of Nentucky extends to and over the entire soil and waters within the limits described in the preceding section, except so far as she may ceded jurisdiction to the Unlted States for national purposes.

Each county in this Commonwealth, whose boundary is described in part by the Mississippi and Ohio rivers, shall be considered as bound in that particular by the state line; and the islands thereof shall be in the respectibe counties holding the main land opjosite thereto, within this state; and the several counties and tribunals thereof shall hold and exercise jurisdiction accordingly Carroll's statutes Revised statutes of Lentucky, pp 158. Acts of Ky. Gen Assembly 1851-1852, pp 226.

Appendix 46

Thos. Letcalfe Gov. 1829. Amos. Nendall \& Co. for the state.

A Resolution relative to running and larking the boundary line between 
this state and Tennessee.

Approved Jan 29. 1329.

Whereas doubt exist as to the true boundary line between this State and the state of Tennesseee, whereby the citizens of this state experience great difficulty and inconvenience, Therefore;

Resolved by the General Assembly of the Commonwealth of Kentucky, That his excellency, the Governor, be requested to apply to the Executive of the state of Tennessee, to enter into arrangenents to cause to be ascertained and plainly mariked, the dividing line between said States, east of the Tennessee river, agreeably to the compact between the states entered into on the 2nd day of February 1820, concerning said line; and that he select and appoint the necessary surveyors and agent to act on the part of this State, with such person or persons as ahall be appointed on the part of the State of Tennessee; and that in the event the Governor of Tennessee falling to appoint such agent, then, that the Governor cause the said line to be run and ascertained by some skilful surveyor, fron some known point in Walcer's line, near the southeast corner of Trigg county to the Tennessee river; and also that part of the line adjoining simpson and Allen counties, according to sald compact; and to have the same plainly marked, and a plat to be returned to the Secretary's Orfice as soon as the nature of the business will admit; and the Auditor is authorized to issue his warrant on the Treasurer for such sum as the Governor may deem necessary to cover the expenses of running and ascertaining such boundary line.

\section{Appendix 47}

1830

Bright and Lunsell ran a line across the southern barders of Allen Simpson and Trigs counties; 222. Laws of Ky. Vol. VIII. Joseph Desha. By authority, Jacob H. Haleman, Thos. Letcalfe. Gov. 
Resolutions.

Report of the Comittee, appointed to make examination respecting that part of the line, between the states of Kentucky and Tennessee, adjoining the counties of Trigg, Simpson etc.

Approved, January 151831

Your committee will state, that they have carefully and minutely examined the claims of the states of Tennessee and rentucry, respecting those portions of Territory, in the counties of Simpson and Trigs, the boundary line of which seems to be ungettled, and somewhat the subject of dispute. To come to any correct and definite conclusion, it of course became necessary for your committee to have recourse to such testinony, as they could procure, respecting the subject. This testimony consested of the plat and report of lissrs. Bright and unsell, the late commissioners appointed by the executive authority of the respective states above named, to ascertain, run and plainly mark the dividing line, between the states of Tennessee and Kentucky, so far as that line concerns the counties of Trigg, Simpson, etc. In addition to this evidence, we had also the explanatory testimony of several gentlemen whose knowledge of the subject, enable them to give us every necessary information, respecting that part of Walker's line, adjoining the aforesaid counties, as the same is reputed understood and acted upon, by the said states, their respective officers and citizens. It seems that the aforesaid commissioners, in the discharge of the duties assigned them, by their late appointment, to run and mark said line after having found and retracted the sane, from the south east corner of Allen count, to the county of Simpoon, and along said county, till they come to a certain be ch tree, in the line, near Drake's creek, found tiat the said reputed line, here took an offset, south $62 \frac{1}{2}$ west, to a certain black jack, standing in the road leading from Nashvilie to wexington, and from thenco taking another offset, northwardy, to a certain gum tree, standing in 
Walker's original line. It appears that the territory of country, included in this triangular space, between the beech, black jack and gum, contains some ten or fifteen families, and has always been considered as belonging to Lentucky. The remonstrances of those citizens to the Legislature of rentucky, in which they loudly complain of the danger which they conceive themselves to be subjected to of being stricken from the state to which they have heretof re belonged, whose laws and government they know, and have ever recognized and obeyed, and solemnly protested against being expotriated from the country of their choice, has been laid before and examined by us.

Your committee are unamniously of opinion, that the state of Tennessee, ought to recognize the right of kentucky, to retain this portion of territopy; and that it would be equally improper and unjust, for sentucizy to relinquish or Tennessee to claim the same.

The above named triangular line, has ever been reputed, understood and acted upon, as determining the territorial limits of the two states, by the citizens of the country. It nas always been known, as the line separating the jurisdiction of the respective states. The civil rights of those citizens, have always been subject to, and determined by the laws of kentucky. Many of trose are, perhaps, pending and unsettled, consequently, great in convenience, not to say injustice to those people, would be the result of detaching them from sentucky. We trust that this will not be done.

With respect to that part of the line adjoining Trigg county, which also seems to be unsettled, it appears that the aioresaid commissioners found and plainly marked Walkers origional line, from the south east corner of Trigg County till within about one mile of Cumberland river, where it terminated; but the commissioners extended the line, according to its course at the termination, across to the Tennessee river.

It appears that they then run due north, from the point where they 
struck the Tennessee river, until they intersected another line said to have been run by Walker, eastward, by way of correction of his origional. Ine, on the east of umberland river. The citizens west of the Cumberland river, included between those two lines, appear to have always been considered as belonging to the state of Tennessee, and they have even been subject to the jurisdiction of her lawg.

Your committee are of opinion, that this part of the county which includes the great est portion of doubtful territory, ought still to belong to Tennessee, aking the lower or north line, between the rivers Cumberland and Tennessee, the permanent division line, between the States, so far as respects the country between the said rivers. But your connittee are unanimously of opinion, that the origional line of Walker's, traced and marke by the comissioners, till within about one mile of the cumberland river, and by them extended to the river, In Trigg county, ought to be established and recognized, as the division line, between the two states. It appears that most of the citizens north of that line, have heretofore considered themselves as -entuckians, and belonging to Trigs County; it appears also, that those citizens protest ajainst being detached from ientucky.

Your committee are therefore of opinion, that Walker's origional line as narked by said commissioners, to Cumberland river, thence down the middle of said river to the line run by walker, eastwardy from the Tennessee river, by way of coreection, to this line east of to the Cumberland river, and thence with said line, to the Tennessee river ought to be recognized and established by the two states, as the permanent division line of their territory and jurisdiction. And they would recommend that, the proper authorities of the state of Tennessee, be requested to recognize, and requested to co-operate with the proper a dhorities of the state of lentucky in establishing the line, as marked out by the above named commissioners, as apjears from the plat 
and report, and as qualified by this report, to be known and acted upon in future, as the permanent division line, separating the territory, citizenis and civil jurisdietion of the respective states; and your comittee, would further recommend, that provision be made by law (in the event of the concurrence of the states respectively, in the establishment of the said line, as above recommended, ) for the interest and rightg to land adoining said line, to be tried and governed by the laws of Lentucky or Tennessee, as those persons deriving titles to land from those states respectively, may be thrown by location of the permanent line, between the said states; Wherefore,

Re solved by the General Assembly of the Commonwealth of Aentucky That the Governor of this commonwealth, be directed to transmit to the proper, requesting a recognition of the line, which has been ascertained, run and plainly marked by Bright and Lunse11, (the late commissioners appointed by the executive authority, of the respective states, for that purpose) as qualified by this report, as the permanently established line of division, between the states of Tennessee and Lentucky.

Rēsolved further, That the governor of this commonwealth, be directed, in case the state of Tennessee falls, or refuses to accede to such proposal, to cause the said line to be settled and ascertained by the appointment of arbitrators by the executive authroity of the respective states, or otherwise, as he may deem proper.

\section{Appendix 48}

1831 Acts Tennessee chapter 61.

An Act to provide the means by which the existance and locality of Lathews line is to be established. December 20.

Whereas many disputes have arisen and are likely to arise between persons claiming land under grants from the state of sentucky, and persons claiming under grants from this state; and whereas, it may become necessary in the disputes aforesald, to prove the existance and 
locality of the line lately run by Lathews, a mathemetician appointed by the authroities of the state of kentucky to carry into effect the provisions of the compact between the two states; for remedy whereof,

Sec. 1. Be it enacted, etc; That in all suits now pending or that nay hereafter be commenced, in any of the courts of law or equity in this state, It shall be competent to prove the running and locality of said line by paral proof, and in no case shall the production of the appointment on the plat of said survey to required in suits in any of the said courts.

1833

Appendix 49

Resolution no 9. rassed possibly last of November.

A resolution to extend the jurisdiction of the state of Tennessee to Walker's line.

Whereas, by compact between the states of sentucky and Tennessee, Walker's line is established as the true boundary line between said states, which line was surveyed and ascertained in 1830, by commissioners on the part of said states; and whereas, there is a portion of people settled south of Walkers line adjuining the county of Simpson, and attached to the counties of Robertson and Sumner, and between Walker's line and a line commencing on said line and a beech at Drake's creek, running south six y-two degrees west to a black jack on the Lexington road, thence northwardly to a certain gum tree standing on Walker's original line who clalm to be citizens of the State of Kentucisy, when they are within the ascertained limits of the State of Tennessee, the commissioners having disregarded sald of fset, and established Walzer's line to be a direct west course from said beech to the gum, being about six miles and a half long; therefore,

Resolved, etc. That the jurisdiction of this state be extended over the said described country up to sald Walker's line, running a direct course from sald beech to said gum, as marked by said commissioners; 
and all persons living within the limits of the said described country, are cltizens of the stete of Tennessee, and subject to our laws, and are required to obey and observe the same; and the officers of this state are authorized and required to execute process in sald described country, and make return as in other cases Land Laws Tennessee 648

1833

Appendix 50

$$
\text { Acts of Ky. Chap 125- pp } 107
$$

An Act to appropriate a part of the vacant land lying between Walker's line and the latitude $36^{\circ} 30^{\prime}$ in North in the state of Tennessee for the purpose of improving and finishing the road leading from Monticello, Whayne county, to the State line in a direction to Jacks borough and to Barboursville.

Sec. 1. Be it enacted by the General Assembiy of the Commonwealth of Sentucky, That the Register of the Land office be and he is hereby authorized and required to issue a land warrant for six thousand acres, in the name of the county court of Wayne, to be located in not less than fifty acre surveys, on any vacant land lying in the territory between Walker's line and latitude thirty six degrees thrity minutes North, and South and East of Wayne county, or on any vacant land in Wayne county, or in that part of Whitley countie lying south of Gelie creek; and the sald county court is hereby authorized to sell or have located, surveyed and potented, within the bounds above prescribed, the said six thous nd acres of land; and the Register of the Land ufice is hereby required to issue potents therefore, without fee; and the said county court is authorized to lay out the proceeds from the sales of said warrant, on that part of $t$ e road most thinly inhabited between the Tennessee state line and Rock creek, near Jonathon Blevens. Acts completed to $-1841-$ 
1836 Resolution no. 9. February 12

Whereas by compact between the state of Sentucky and Tennessee, Walker's.line is established as the true boundary line between said States, which line was surveyed and ascertained in 1830 , by commissioner on the part of said States; and

Whereas, there is a portion of people settled south of Walker's line adjoining the county of Simpson and attached to tire counties of Roberston and sumner, and between Walker's line and a line commencing on said line on a beech at Drake's creek, running south sixty-tow degrees west to a black jack on the Lexington road, thence northwardy to a certain gum tree standing on Walker's origional line, who clain to be citizeng of tie state of sentucky, notwithstanding they are, in fact within the ascertained limits of the state of Tennessee, the commissioners having disregarded said offset and established walker's line to be a direct west course from sald beech to the gum, being about six miles and a half long; and

Whereas, the Legislature of this state, passed a resolution in 1833 that the jurisdiction of this state be extended over the said described tract of country up to $W_{a} l k e r ' s$ line, running a direct course from said beech to sald gum as marked by said aommissioners, and all persons within said bouniaries were required to obey and observe the laws of this state; and

Whereas the Legislature of the State of Nentucky have failed to ratify the survey or line run by the commissioners on the part of both States in 1830, as was done by the state of Tennessee in 1833.

Resolved that the Governor of this state be requested to communicate with the Governor of the State of Nentucky, requesting him to lay the same bef re the Legislature of that state for tine purpose of having sald line ratifled.

Land Laws Tennessee 049. 
1844 Jan. 2 J Chap. 128 Appendix 52

An Act to adjust the boundary line between this state and the State of sentucky.

Whereas doubts have arisen as to the true line of boundary between this state of lentucky, on that jart of said line which extends from the Reelfoot rilis to the Mississippi River. For renedy whereof,

Sec. 1. Be it enacted etc, That two persons be appointed by the Governor of the state, to meet such commissioners as may be apointed by the state of centucky on said boundary, whose duty it shall be to run and remark said line, where it has been heretof re run and marked by the authority of rentucky, and to run and mark a new line where none has been heretof re run and marked by a thority as af resaid; and the line which nay be so run and narked by said commissioners shall be considered and held the true line of boundary between the states of Tennessee and lentucky, from ant after the running and marking theresf.

Sec. 2. That two persons be appointed by the Governor of Te nnessee, to meet such comissioners as may be appointed by the state of Kentucky on that part of the line which divides the state of sentucky from the State of Tennessee, that passes between the counties of stewart in the State of Tennessee, and Trigg and Cristian Counties in the state of sentucky, whose duty it shall be to commence at a point in said dividing line whe the line between the two states is known to be and to run and remark saidline where it has been heretofore run and marised under the compact between the states of sentucky and Tennessee, and to run and mark a new line where none has been heretof ore run and Inarked from said point, known in the line to the Cumberland River; and the line when run by sald comissioners, shall be considered and held the true boundary line between the states of sentucky and Tennessee, from and after the running and marzing thereof.

Sec. 3. That a copy of this act snall be transmitted by the Governor, 
to the Hegislature of hentucky at their next session with a request that said Legislature will take such action upon it as nay be necessary to effectuate its object.

Sec. 4. That said commissioners shall by joint report, commicate to the Governors of their respective States, wnat they nay do in the premises; and the Governor of Tennessece shall communicate the same to the succeeding -egislature of this state. Land Law Tenn. 649.

\section{Appendix 53}

An Act to run and re-mark a portion of the boundary line between the States of hentucky and Tennessee.

Whereas, Doubtg nave arisen as to the true line of soundary between the states of kentucizy and the State of Tennessee, upon different portions of the line dividing said states; therefore,

Sec. 1. Be it enacted by the General Assembly of the commonwealth of sentuciny, That tie Governor be authorlzed to appoint two comissioner as may be appointed upon the part of the state of Tennessee, whose duty it shall be, to run and re-mark said line, where it has beennoretofore run and narized oy the authroities of tre tho stetes, that is to gij; from the Reel Foot Hills, to the wississippi river, and, also that portion of gaid line that divides the county of stewart, in the state of Tennessee, from the counties of Christion and Triggs in the state of sentucky.

Séc. 2. Be it further enacted, That said comnissioners, shall, by a joint report, communicate to the Governor their proceedings under this Act, who shall communicate the sane to the eext wegislature of this state.

Sec. 3. Thit the Governor shall communicate the passage of this act to the Governor of the state of Tennessee. 
1846- $\mathrm{R}_{e}$ solution No. 28 App. Feb 2.

Resolution to require the Governor of the state of Tennessee to open a correspondence with the Governor of the State of Hentucky.-

Whereas, much inconvenience has heretofore arisen, and is now experienced by citizens residing in the nortiern part of the state of $\mathrm{T}_{\mathrm{e}}$ nnessee, between the lines commonly known as Walker's and Steel's line, in consequen of the difficulty and expense in procuring titles to land under the provisions of the fifth article of the convention entered into between said states on the $2 d$ of February 1820. Said article provides that all lands now vacant and unappropriated by any person or persons clalming to hold under the state of North Carolina or Tennessee, east of the Tennessee River, and north of the parallel of Latitude thrity-six dejees and thirty minutes norti, shall be the property of and subject to the dispositon of the state of sentucry, which state may make all laws necessary and proper for disposing of and granting said land, or any part thereof, etc., Now, therefore, in view of the many difficulties arising out of said article, which requires the citizens of one sovereign state to make application to the officers of anotiner sovereign state for the supveying of lands and granting titles to the same, which requires the citizens of Tennessee to hold evidence of title to land within the acknowledged boundaries, which titles aust emanate from the Governor of sentucky, which requires the Citizens of Tennessee to apply to Lentucisy for surveyors to survey said lands; and in view of the many difficulties resulting to the citizens of Tennessee from this state of things;

Resolved, etc., That the Ixecutive of the State of Tennessee, be, and he is hereby required to open a corcespondence with the Executive of Kentucky during the present session of the Legislature of said last mentioned State, if practicalbe, touching the lands claimed by Lentucky within the limits of the state of Tennessee, with a view of acquiring 
them by purchase and all soverelgnty over them; of ascertaining the estimated value of the same and of the feelings and disposition of our sister state toward adjusting the matter in such way as to give to tine Stateof Tennessee a perfect jurisdiction over all the territory within her boundary line, and make report of the same to the next General Assembly of this state.

Appendix 55.

Resolution directory to the Governor of Tennessee.

By in act of the General Assembly of Tennessee, passed the 20 th of January, 1844, making it the duty of the Governor of Tennessee to a point two commissioners to meet two commissioners on the part of Lentucky, to run and re-mark the state line between Tennessee and Lentucky, said commissioners performed the duty assigned to them, and made their report to the last General Assembly of this State, then. in session, which report was concurred in, but sentucky has taisen no action, there upon; therefore,

Resolved, etc., that the Governor of Tennessee be requested to correspond with the Governor of Kentucky, asking action on the part of Lentucky, upon said report, and the communication tinereof to the Governor of Tennessee, so that the same may be laid before this veneral Assembiy. 1848- Resolution No. 2J. Ado ted Jan 11

\section{Appendix 56.}

Preamble and Resolutions confirming tine report of the comissioners flxing the boundary 11 e between Tennessee and Lentuciry.

Whereas the Legislature of Tennessee, on the 20th January 1844, pagsed an act for the appointment of a joint comnission, consisting of two comissioners from the state of Tennessee, to net two like comissioners upon the part of the state of sentucky, to run and re- 
mark certain portions of the boundary line between said states, and requested the concurrence of the regislature of sentucky in the appointment of such commission; and whereas the General Assembly of Kentucky did, on the 29th day of January 1845 pass an act providing for the appointment of two commissiones on the part of Kentucky, to meet and act with the Commissioners on the part of Tennessee, for tie performance of said duty; and whereas, under the provisions of said acts of the Legislatures of their respective states, the Governor of the state of Tennessee did, on the 19th day of April 1845, appoint Clemònt $W$. Nance and William P. Lctain, Esquires, as commissioners upon the part of the State of Tennessee, and that the Governor of Nentucky did on the 8th of May, 1845, appoint Joseph R. Underwood and Sandford Duncan, Esqrs., Comissioners, upon the part of Kentueny; but the said Joseph R. Underwood, Esqr., having resigned said appointment on the 22d daj of september, 1845, without having acted at all, the Governor of Lentucky, appointed Cons cant A. Wlison, usqr, in his place; and whereas, the said Constant A. Wilson and Sandford Duncan, on the part of Kentucky, and the said Clemont W. Nance and Wm. P. Welain did, on the 18th of Jet., 1845, proceed to discharge the duties assigned to them, and, by their joint report to each of their respective states, bearing date Nov. 8th 1845 , did report that they had performed the duties assigned them, and returned to each of their states fair copies of the maps of their lives as run and narked by them as part of their said reparts; and whereas, the Legislature of Tennessee have concurred in sald report, and has by law recognized the lines run and re-marked by the said joint Commissioners, as the true boundary lines between those portions of the sald states to which they refer; and whereas, the General Assembly of Kentucky on the -.--day of -..- 1846, passed an act to compensate the said Commissioners, on the part of Kentucky, but failed to adost and concur in the said report or to ratify the same 
and recognize the lines so run and narked, by the Commissioners, as the true boundary line between those poart ons of said states, to which the line refers; and whereas, his exeellency, the Governor of this Comnonwealth, called the attention of the General Assembly of this Commonwealth to the uncertainty wilch prevails in relation to those portions of tile boundary lines of the two states; and whereas, it is the ardent wish and desire, of the commonwealth of centucky, as well as her true policy, to cultivate feelings of amity and kindness with all her sister states of this confederacy, and especially with the State of Tennessee, extending along her entire southern boundary, and united to her by a similarity of interests and political institutions. Therefore,

Resolved by the General Assembly of the Commonwealth of sentuc ky, That the boundary line between tine county of Stewart, in the state of Tennessee, and the counties of Christion and Trigg, in the state of fentucky, beginning at the N.E. corner of Stewart county, in the state of Tennessee, at a point designated on the map by the letter $A$, and, running thence to the point designate $d$ on the map by the letter $G$; thence northwardly, two iniles and thrity eight poles, to a point designated on said map by the letter $\mathrm{E}$; thence westwardly to a point on Cumberland river designated on tine map by the letter F. as mun and marked by the said Comissioners be established as the true boundary and dividing line between tre county of stewart, in the state of Tennessee, and the counties of Christian and Trigg, in the S tate of Kentucky.

$R^{e}$ solved further, That the line run and remarked by the said Commissioners, from the foot of the Reel foot hills to the soutnwestern corner of Fulton county, on the uississipji river, below Madrid, as the same is laid down and designated on the naps accoinpanying the said report, by the letters A.B.C. to where it strikes the 
the Nigsissippi river, and from the point designated on said map by the letter D, on the Mississippi river, across New fadrid Bend, to the point on said river designated by the letter $E$. be and the same is hereby recognized, ratified and established, as the true boundary and dividing line between the States of rentucky and Tennessee, so far as the sane extands.

Resolved, That His Excellency, the Governor, be and he is hereby requested to cause a copy of this esolution to be transmitted to the Governor of Tennessee, with a request that the same may be laid before the Legislature of his State. 1849 February 28 No. 14

\section{Appendix 57}

1851 Resolution No. 55. --Adopted Dec. 2.

A cesolution appointins commissioners to negotiate with the Legislature of Lentucky for the cession of a small portion of territory belonging to Kentucky, to the State of Tennessee.

Whereas, there are, according to the manner in which the boundary line between Tennessee and rentucky was run, about twelve sections of land belonging to Kentucky lying between the northwestern boundary line of Tennessee and the Missippi Kiver, isolated from the territory of sentucky, and whereas, the inhabitants of said territyor are desirous an account of their location; of being annexed to Tennessee. And Whereas, it would be an important acquisition to Tennessee georaphically thereiore.

Resolved, ete; That Maj, S. H. Cockran and Col, kobert w. Lewis be a pointed conmissioners, and the Governor of this State is authorized to commission them as such, to attend the present session of the Legislature of rentucky, to negotiate for the cession to Tennessee of the above mentioned territory and that they be authorized to offer a 
fair equivalent in money to the state of sentucay for said territory, and that they report the terms upon which said territory can be acquired, if acqiired at all, to the present session of the Legislature, if practicable, if not, then to the next session of the regislature of this state.

Appendix 58

An act to appoint comissioners to re-mark the state line between Tennessee and Lentucky, east of the Mississipji River,

Section 1. Be it enacted, etc., That two persons be appointed by the uvernor of the state to meet such commissionerg as may be appointed by the state of Nentucky to run and re-mark the line established by the compact between the States of Tennessee and sentucky. Beginning on the east bank of the Hississippi Kiver, running thence to the Eastern boundary of the state of kentucky, putting up a large stone every five miles, provided, when rock or ston cannot be conveniently had, posts of some durable wosd be substituted. That said comissioners shall have full power and authority, and it is hereby made treir duty, to employ a fieild party, to consent of one engineer, one surveyor, one back-sight man and one oxman, and such others as may be necessary. The engineer and survejor to be well qualified to mase said survey upon scientific princlples; said commissioners to superintend tie work.

Sec. 2. That a copy of this ast shall be transmitted by the Governor to the Legislature of sentucky at its present session, with a request that gaid Legislature will take such action upon it as may be necessary to effect its object. And so soon as action thereon shall be taken by the Legislature of the State of Kentuciry and the Governor of this State and of the state of Aentucky shall have appointed commissioners as provided in the first gection of this act. it shall be the duty of said commissioners to proceed as soon as procticale to the perporinance of the duties required of thern. and to have or cause the survey to be 
completed at an early a date as may be practicable.

Sec. 3. That sald commissioner's shall be joint report communicate to the Governor of their respective States, what they may do in the premises, and that the Governor of Tennessee shall comnunicate the same to the succeding Legislature of this state; said comissioners shall accompany their said report with a nap of their survey, showing the re lative position of former lines to the line of survey made by them, and such other information as may be necessary.

Se c. 4. That the domptrolier of the Treasury of this state whenever directed by the Governor, shall issue to the Commissioners appointed by him ais warrant upon the Treasurer of this state for the sum of three thousand dollars to be by them appropriated to the purchase of necessary instruments and the cost of maring s aid survej.

Sec. b. That said Connissioners shall also in their report show the time tat each of them and each of the field pariy was necessarily en aged in the perfor ance of their respective duties in making sald survey, the amount paid for his services and also what future amount, if any, is necessary to pay the costs of the same.

Sec. 6 That said commissioners shall cause to be prepared and filed in the office of the secretary of state a careful and full topographical map of the survey this made, exhibiting the positions of the country and embodying all that geographical information that can be incidentally sbtained in maxing such surveys.

Daniel S. Donelson

Sp. H. R.

John C. Burch

1858 passed Jan. 29. Chap. 26. Sp. Sen.

Appendix 59.

1858 Feb. 17 Acts of Kentucky. pp 82-Chapter 789.

An Act for running the state line between sentucky and Tennessee. 
Whereas, an act passed by the legislture of the state of Tennessee, entitled, an act to appoint Commissioners to re-mark the state lines between Tennessee, and Kentucky, east of the wississippi river, has been presented to the General agsembly of Kentucky, for its consideration; and in order to have the line between the state of sentucky and Tennessee re-marked.

Be it enacted by the General Assembly of the Comnonwealth of Kentucky; Sec. I That two persons be appointed by the Governor of the State to meet such commissioners as may be appointed by the state of Te nnesse to run and re-mark the lines between the states of Tennessee and Kentucky; beginning on the east bank of the wississippi river, running thence to the eastern boundary of the state of sentucky, putting up a large stone every five miles; Provided, when rock or stone cannot be conveniently had, posts of some durable wood be substituted. That said Comissionerg shall have full power and authority, and it is hereby made their duty, to employ a field party, to consist of one engineer, one surveyor, one back-sight-man and one oxman, and such others as may be necessary.

The engineer and survejor to be well qualifled to nake said survey upon scientific principles, Said commissioners to superintend the work.

Sec. 2. That a copy of this act shall be transmitted by the Governor of Lentucky to the Governor of Tennessee; and as soon as the Governor of this state shall have appointed Commissioners, as provided in the lst section of this act, it shall be the duty of said commissioners to proced, as soon as practicable, to the performance of the duties required of them, and to have or cause the survey to be completed at as early a date as nay be practicalbe.

Sec. 3. That sald Commissioners shall, by a joint report, Communicate to the Governor of their respective states, what they may do in the 
premises;and that tine Governor of Kentucky shall communicate the same to the succeding legislature of this state; said Commissioners shall accompany their said reprot with a map of their survey, showing the relative positions of former lines to the line of survey made by them, and such other information as may be necessary.

Sec. 4. That the Auditor of this state, when ever directed by the Governor, shall issue to the Commissioners appointed by him, his warrant upon the Treasurer of this state for the sum of three thousand dollars, to be by them appropriated to the purchase of necessary instruments, and the costs of making said surve.

Sec. 5. That said Comissioners shall, also, in their report, show the time that each of them, and each of tie field party, was necessarily engaged in the performance of their respective duties in inaking said survey, the amount paid to each for his services, and also what future amount, if any, is necessary to pay the costs of the same.

Sec. O That said Comissioners shall cause to be prepared and filed in the office of the secretary of state, a careful and full topozraphica map of the survey thus made, exhibiting the features of the country, and embodying all the geographical information that can be incedentally obtained in making such survey.

Sec. 7 This act to take effect from its passage.

\section{Appendix 60}
1859 Dec. 14 No. 3

Resolution referring the Governor's message, so far as it relates to the poundary line between sentucky and Tennessee to a joint committee. Resolved by the General Assembly of the Commonwealth of sentucky. That so much of the Governors message as refers to the running of the boundary line between the states of sentucky and Tennessee, togetner with the report of the commissioners appointed to accomplish that work, be referred to a joint select committee of the House and senate, 
consisting of five members from the House and three from the Senate.

Appendix 61

An Act relative to the dividing line between the States of wentucky and Tennessee, and allowing compensation to the persons engaged in running the same.

Be it enacted by the General Asgembly of the vommonealth of sentucizy;

Sec. 1. That the boundary line recently run and made between the States of sentucky and Tennessee, by comissioners respectively appointed by said States, be, and the sane is, approved, adopted, and recognized as the true boundary line between sald states, The Lentucky comissionerg gustin P. Cox and Charles A. Briggs acted under a law approved February 1\%, 1858, entitled "An act for running the state line between sentucky and Tennessee."

Sec. 2. That the Auditor of Public Accounts be directed to draw his warrant upon the Treasurer in favor of the following persons, for the several sums hereinafter named $1 e$;

1. In favor of Austin P. Cox, as the balance due him for acting as commissioner, \$2000.00

2. I.f.o. Charles 4. Briggs amount due him for acting as commisgioner on the state boundary line survey $\$ 1900.00$

3. If f. o. J. rillsbury for $\$ 980$, as balance due him for services as chief engineer on said line.

4. I. f.J. G. Trafton for $\$ 719$, as balance due him for services as chief engineer on sald line

5. I.F.J. A Hensley for $\$ 870$, due hin for services as assistant engineer or surveyor on said line.

6. I.f.o. W. E. Cox for $\$ 596$, for services on said line as flagman and chainman. 
162

7. I. f. o. M. Y. Brown for \$331.75, balance due him for services as flagman and chainman on said line.

8. I. f. O. H.C. Hines for $\$ 290$, for services on ald line as flagman and chainman.

9. I. f. 9. H. W. Dulaney for $\$ 604.50$ balance due him for services as flagman and chainman on said line.

10. I.f.o. C. G. Graham for $\$ 583.45$ balance due him for services as flagman and chainman on said line.

11. 1.f.o. Charles 4 . Briggs for $\$ 190.25$ balance due J. r. Wooten, deceased, for services as assistant commissary to the corps on said line. 12. I.f.o. Charles 4. Briggs, for Thomas Manning, balance due said Manning as axeman on said line, the sum of $\$ 116.50$

13 I.f.o. Charles 4. Briggs the sum of \$650. for the services of Wilson, Charles, and Henry, slaves belonging to W. V. Loving, said amount for said Loving.

14 I. f. o. Charles if. Briggs for $\$ 79.50$ balance due Tom Tolbert, said amount for Tolbert, for services as axeman on said line. 15 In favor of Charles 4 . Briggs for $\$ 164.35$ due B. C. Greer, for the services of his slave loses on said line

16. I f.o. Charles 4. Brig s for \$40. amount due G. Willis for service on said line.

17 I. fo. Charles 4 , Briggs for $\$ 136.25$, balance due him for the services of his slave wat on said line.

18. I.P.o. Charles 4. Briggs for $\$ 290.25$ balance due W. L. Underwood (this amount for said Underwood) for the services of his slave Tom on said line.

19. I.f.o. Charles H. Briggs for 86.75 , balance on S. H. Jones (this amount for said Jones) for the services of his slave Sam on the said line.

20. I.f.o. S.W. Stanley for $\$ 845$, balance due him for stone furnished 
put up on said line.

21 I.f. o Charles M. Briggs for 1817.79 , the amount advanced by the commissioners for sald line; and also the sum of \$68 interest on same. 22. I.f.o. J. Millsbury for $\$ 300$. to be used in returning and repairing tne insttuments used in running the line.

Sec. 3. That if the appropriation herein made of $\$ 300$, for the repair and return of the instruments, be more than is necessary for that purpose, the balance shall be returned to the Auditor, And $J$. Fillsbury is hereby directed to file vouciners, together with his affidavit, with the Auditor how he appropriates said 300 .

Sec. 4 That fifty copies of the report of the commissioners who run the boundary line herein referred to, together with a lithographic map of the survey, be printed; and that two copies of the same be deposited, at the same time and by the same person or persons who may distribute the public books of this commonwealth, in the clers's office of each county in this state on the state line of Kentucky and Tennessee

Sec. 5. That to wilifully deface or destroy the stone or stones, or any of the same, set up by the commissioners to designate the true boundary line between the states of dentucky and Tennessee, shall be deemed a felony, and punishable by confinement in the penitentiary for a term of not less than one nor more than five yearg.

Sec. 6. That the Auditor is hereby directed to retain $\$ 300$ of the appropriation herein made to the engineer, G. Trafton, until the map authorized and required to be deposited in the office of the secretary of state by the act, entitled "An act for running the state line between Nent icky and Tennessee" shall be deposited there; and the same shall be accepted by the Governor as having been executed in the manner required by said act.

sec. 7. That the Auditor of Public Accounts be required to superintend the printing and lithographing mentioned in the fourth section of this act, and make the contract therefor on the best terms for the 
the state.

Sec. 8. This act to take effect from its passage.

\section{Appendix 62}

1800 Resolution No. 10 Adopted Feb 4. W. of T. 071

Joint resolution in reference to the cession of a portion of Eentucky to Tennessee.

Whereas, there are according to the manner in which the boundary line between Tennessee and Kentucky, as recently run by joint cormissioners of the State of Tennessee and Lentucky, about twelve sections of land, belonging to rentucky, lying between the North boundary line of Tennessee, and the Hississippi River, isolated from the territory of sentucky. And

Whereas, the inhabitants of said territory are desirous, on account of their location of being annexed to Tennessee, And

Whereas, it would be an important acquisition to Tennessee, geo ra hically; therefore,

Resolved, etc., That this General Assembly appoint the Honorable Wm. C. Dunlap, commissioner to attend the present session of the wegislature of Nentucky, to negotiate for the cession to Tennessee, of the above mentioned territory, and that he report his acts and doings in the premises to the General Assembly for their ratification and confirmation.

$$
\text { Appendix } 63 .
$$

1800 Passed Nov. 21. Chap. $79 \quad$ L. L. of T. 653

An Act to ratify and confirm the work of the commissioners appointed to run and re-mark the line established by compact between the states of Hentucky and $\mathrm{T}_{e}$ nnessee.

Sec. 1. Be it enacted, ete, That the report of Benjamin reeples and O. R. Watkins, commissioners for this State and Austin $r$. Cox and 
C. 4. Brigss, commissioners for the State of Kentucxy, dated the eleventh day of November, eithteen hundred and fifty-nine, and filed in the office of the secretary of State, selling forth the operations of the commisioners in fixing establishing and re-marking the boundary between this State and the State of Nentucky, be an the same is hereby ratified and confirmed; and that the line so flxed, established and remarked, and herein after mentioned and specified, and set forth in this act.

Boundary line as in report.

$$
\text { Appendix } 64 .
$$

An Act to authorize the Governor of the state to appoint comissioners to treat with the State of Lentucky for the purchase of that portion of sentucky known as Ladrid Bend.

Section 1. Be it enacted by the General Assembly of the state of Tennessee, That the Governor of this state shall appoint two (2) commissioners, whose duty it shall be to negotiate with the state of Lentucky for the purchase of that portion of sentucky lying immediately north of Lake county, Tennessee, and bounded as follows, to wit: on the north, east and west by the Hississippi River, and on the South by the state of Tennessee,

Sec 2. Be it further enacted, That such Comissioners shall have full power to contract for the sovereignty of such soil mentioned in the first section of this Act, and the purchase thereof, and the payment on the part of the State of Tennessee of such sum as they may deem a sufficient consideration therefor, and report the same to the next General Assembly of Tennessee approved or rejection.

Sec. 3. Be it fuctier enacted, That said Comissioners shall receive as pay for their services, while actually engaged in the performance of the duties imposed by this Act, the pay and miliage now allowed by law to the members of the General Assembly of Tennessee, to be paid on the order of the secretary, contersigned by the Governor; rrovided, the 
number of days does not exceed thirty days.

Sec. 4. Be it further enacted, That this Act take effect from and after its passage.

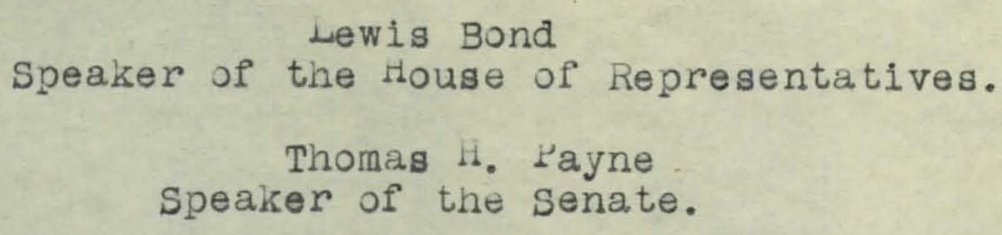

1875 rassed Warch 8; Chap 21.

Approved Warch 121875.

James D. Porter.

Governor. 